\title{
CIRCULATOR SHUTTLE IMPLEMENTATION PLAN FOR THE CITY OF PITTSBURG, CALIFORNIA
}

\author{
A Thesis \\ presented to \\ the Faculty of California Polytechnic State University, \\ San Luis Obispo
}

\begin{abstract}
In Partial Fulfillment
of the Requirements for the Degree

Master of City and Regional Planning/ Master of Science in Engineering
\end{abstract}

(Transportation Planning Specialization)

\author{
by \\ Justin Shiu \\ December 2012
}


(C) 2012

Justin Shiu

ALL RIGHTS RESERVED

ii | P a g e 


\section{APPROVAL PAGE}

TITLE:

Circulator Shuttle Implementation Plan for the City of Pittsburg, California

AUTHOR: Justin Shiu

DATE SUBMITTED: $\quad$ December 6, 2012

Cornelius Nuworsoo

Associate Professor, City and Regional Planning

COMMITTEE CHAIR

Anurag Pande,

Assistant Professor, Civil and Environmental Engineering

COMMITTEE MEMBER

Mike Multari,

Lecturer, City and Regional Planning

COMMITTEE MEMBER

Laura Wright,

Administrative Officer, City of Pittsburg

COMMITTEE MEMBER 


\begin{abstract}
Circulator Shuttle Implementation Plan for the City of Pittsburg, California
\end{abstract}

Justin Shiu

This study examines how a shuttle system can meet transportation needs in Pittsburg. A circulator shuttle connecting major commercial nodes, public facilities, and residential locations, can increase travel options and improve accessibility to key locations. A review of best practices and transit planning standards provides a means to determine the cost of a shuttle service. The base costs of service are then applied to three alternatives for different shuttle route alignments: 1) a north-south route along Railroad Avenue only, 2) a north-south route along Railroad Avenue and an east-west route to Century Plaza, and 3) a north-south route along Railroad Avenue and an east-west route to Century Plaza that also links to Los Medanos College. Each alternative presents the basic system characteristics, which include travel time between proposed stops; the difference in shuttle and automobile travel times; ridership along each route; and cost evaluation of service. Alternatives are evaluated based on comparisons of benefits and costs they can produce in the current environment. Alternative 3 provides the greatest coverage, has the largest potential ridership, and provides access to other major destinations in the eastern half of the city. This should be the ultimate vision for the shuttle service. However, fiscal uncertainties at the moment suggest that it is prudent to select the least expensive alternative, Alternative 1, and slowly branch out the system over time. This would create opportunities for the shuttle system to expand with the future growth of central Pittsburg. 


\section{TABLE OF CONTENTS}

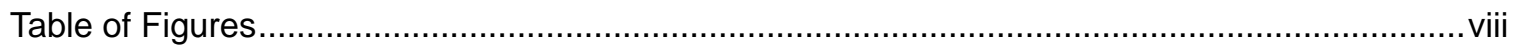

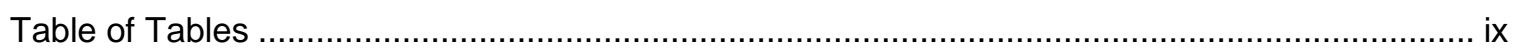

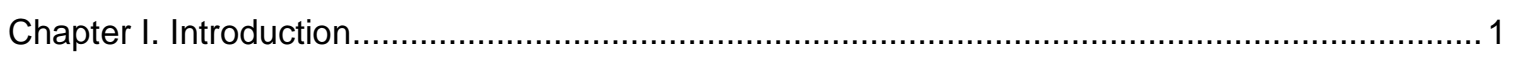

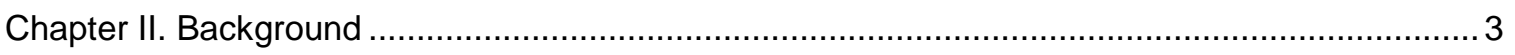

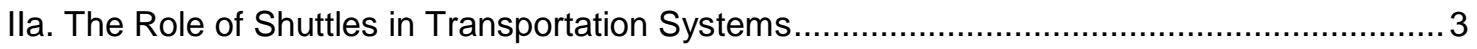

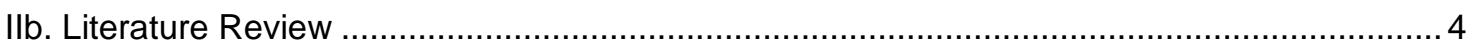

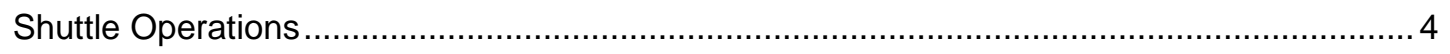

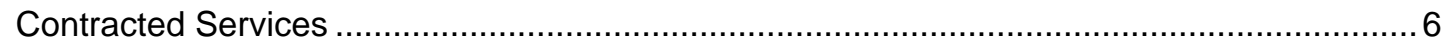

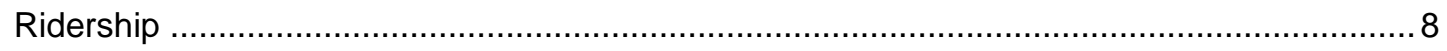

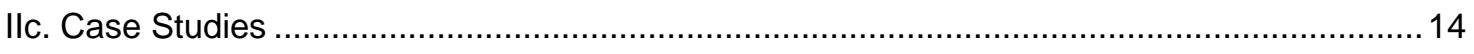

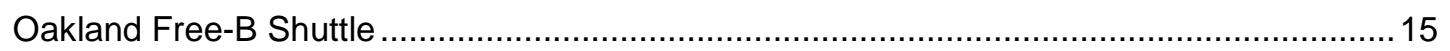

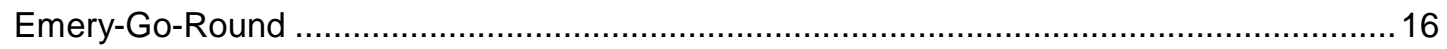

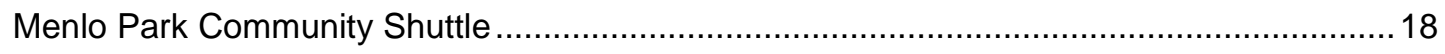

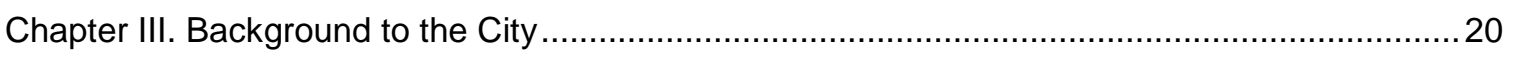

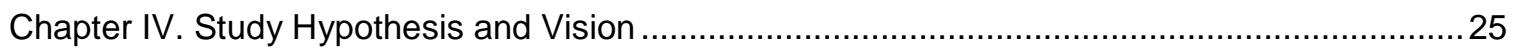

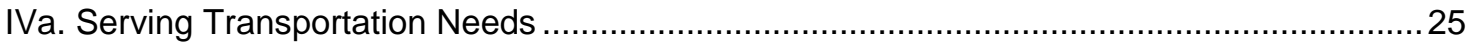

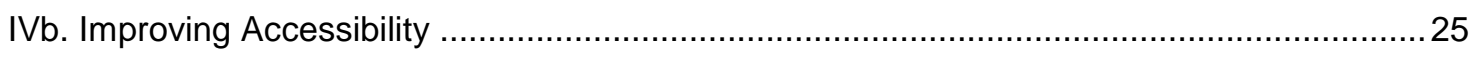

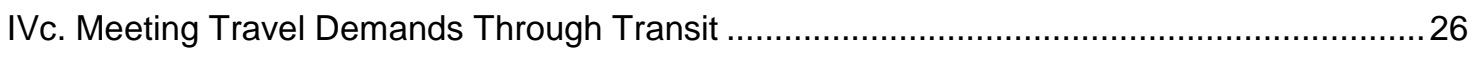

IVd. Reducing Externalities Associated with Automobile Trips ..........................................28

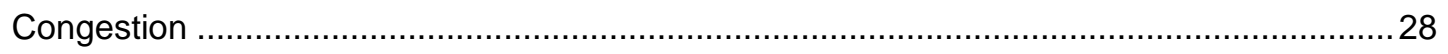

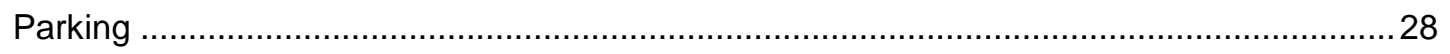

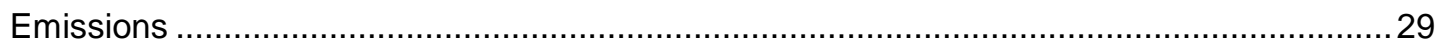

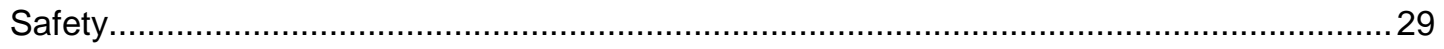

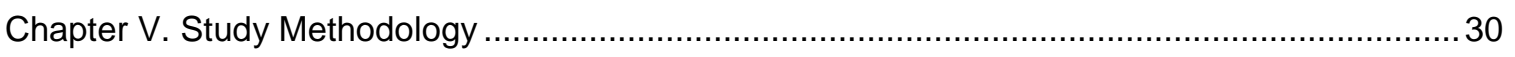

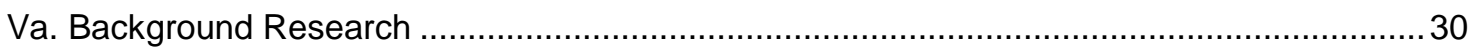




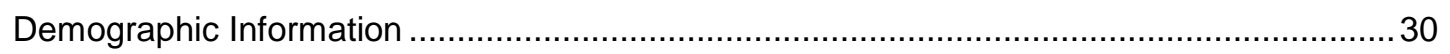

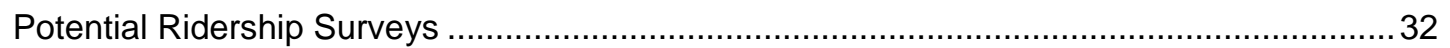

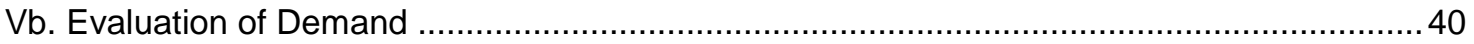

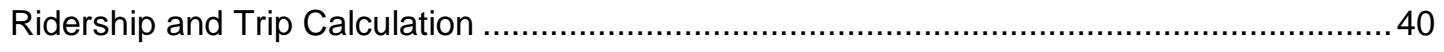

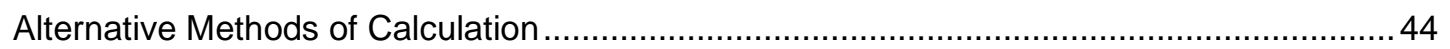

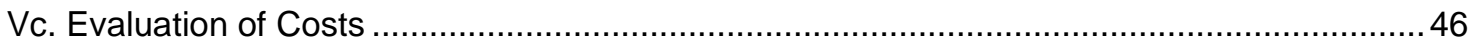

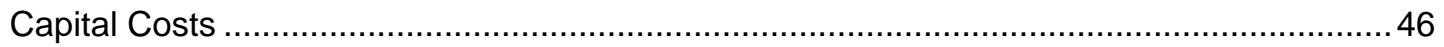

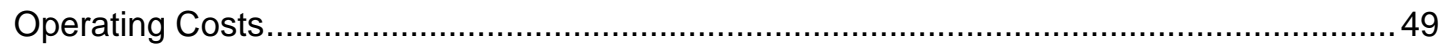

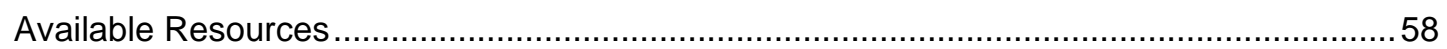

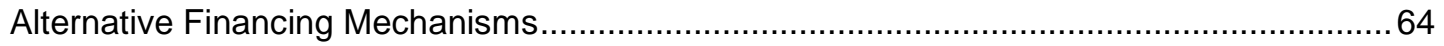

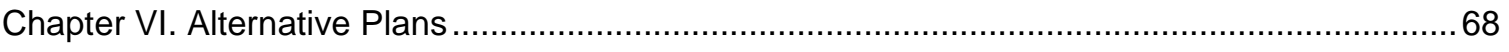

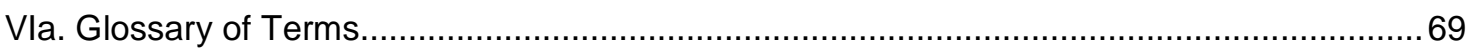

Vlb. Alternative Plan 1: Railroad Avenue Route ....................................................................... 73

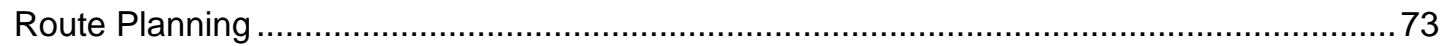

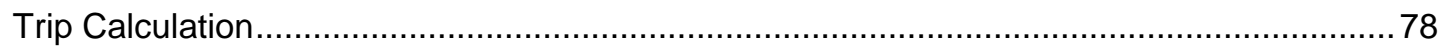

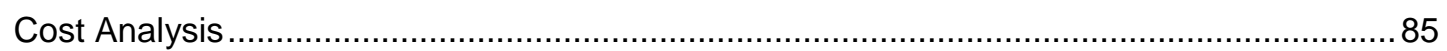

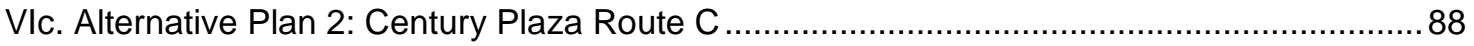

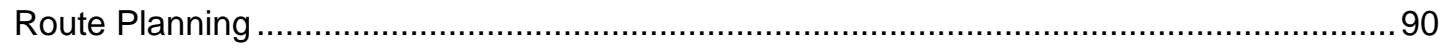

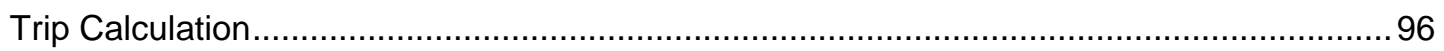

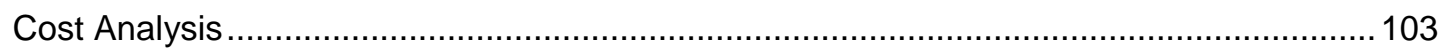

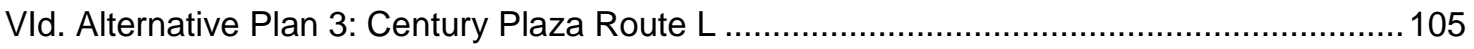

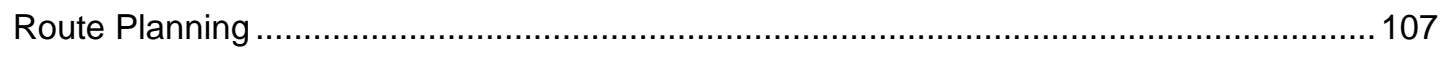

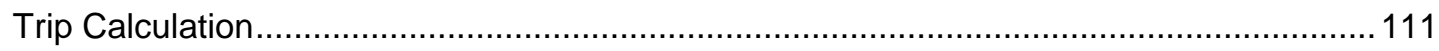

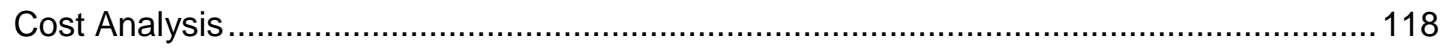

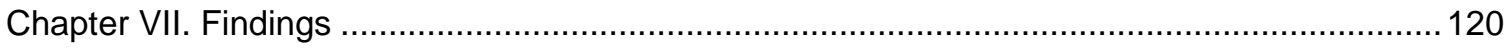

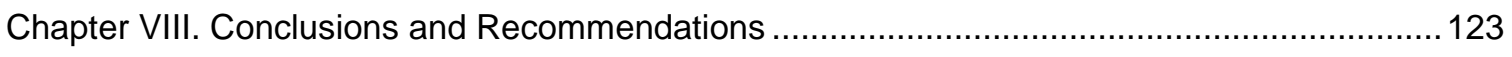

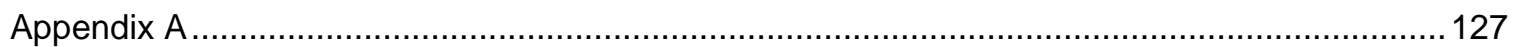




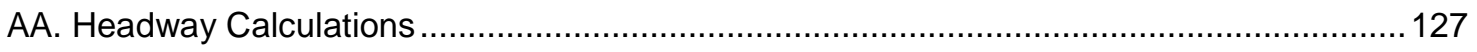

Minimum Travel Time Required to Complete a Route ........................................................ 127

Number of Vehicles Required to Meet a Headway …....................................................... 128

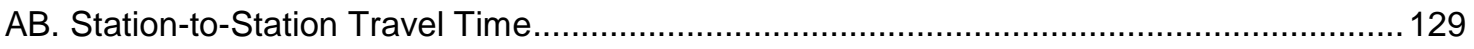

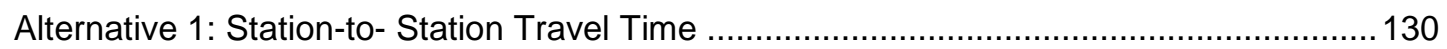

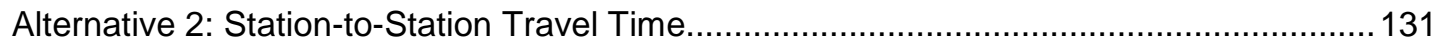

Alternative 3: Station-to-Station Travel Time.............................................................. 132

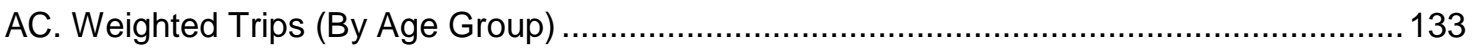

Survey Adjustment Factors and Population Weight......................................................... 133

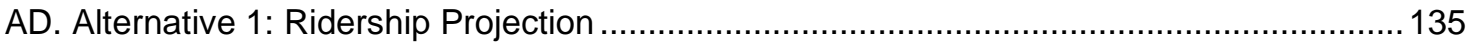

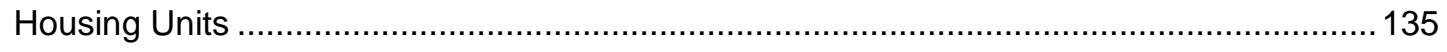

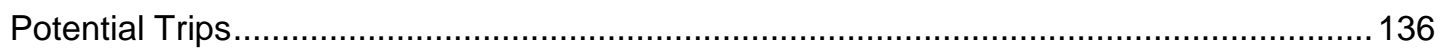

Final Adjusted Potential Trips Made by the Population..................................................... 138

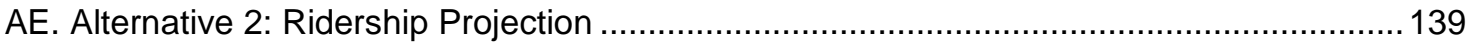

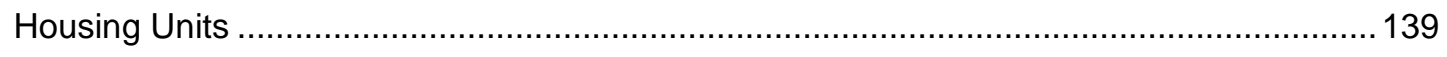

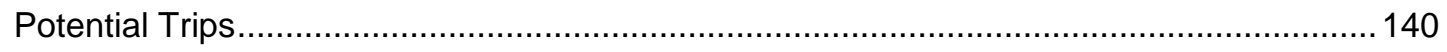

Final Adjusted Potential Trips Made by the Population.................................................... 142

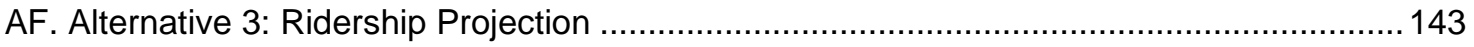

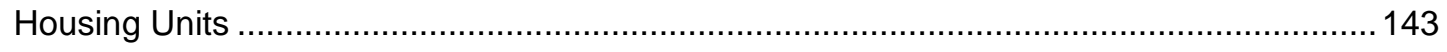

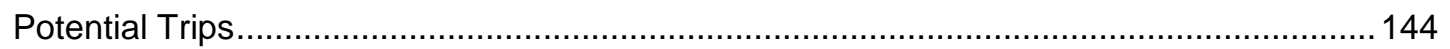

Final Adjusted Potential Trips Made by the Population.................................................. 146

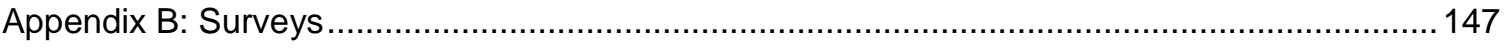

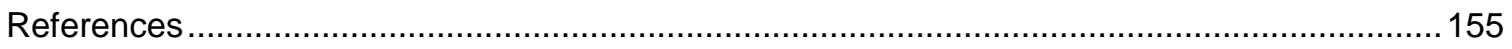




\section{TABLE OF FIGURES}

Figure 1. KEY LOCATIONS IN PITTSBURG .21

Figure 2. POSSIBLE SHUTTLE ROUTES CORRESPONDING WITH TRIDELTA TRANSIT .......27

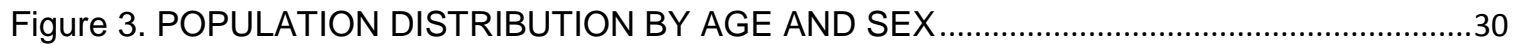

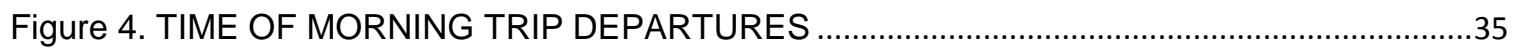

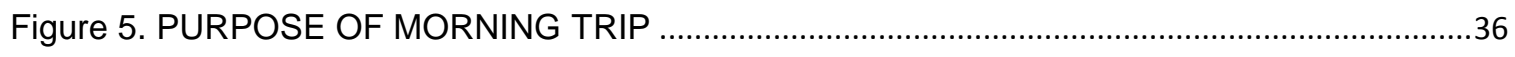

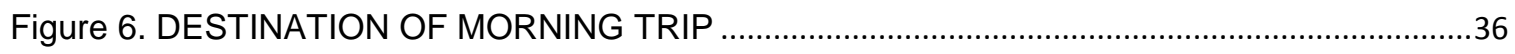

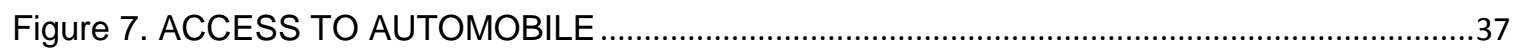

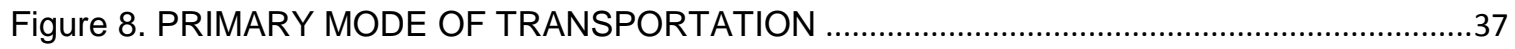

Figure 9. DAILY TRIPS TO A DESTINATION PER PERSON BY AGE GROUP (WEIGHTED) ....38

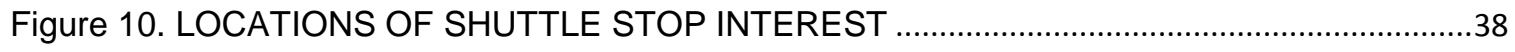

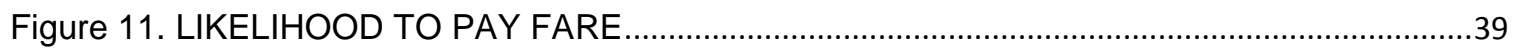

Figure 12. ALTERNATIVE 1 - RAILROAD AVENUE ROUTE: ROUTES AND STOPS .................74

Figure 13. ALTERNATIVE 1: FINAL COMPOSITE OF WEIGHTED DAILY TRIPS TO A

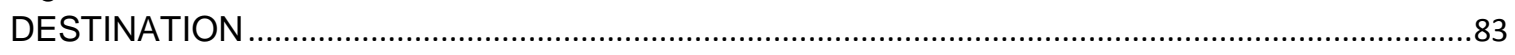

Figure 14. ALTERNATIVE 2 - CENTURY PLAZA ROUTE C: ROUTES AND STOPS .................89

Figure 15. ALTERNATIVE 2: FINAL COMPOSITE OF WEIGHTED DAILY TRIPS TO A

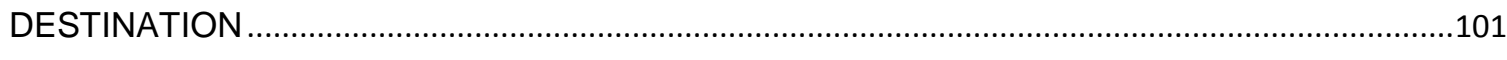

Figure 16. ALTERNATIVE 3 - CENTURY PLAZA ROUTE L: ROUTES AND STOPS ..................106

Figure 17. ALTERNATIVE 3: FINAL COMPOSITE OF WEIGHTED DAILY TRIPS TO A DESTINATION 


\section{TABLE OF TABLES}

Table 1. POPULATION DISTRIBUTION

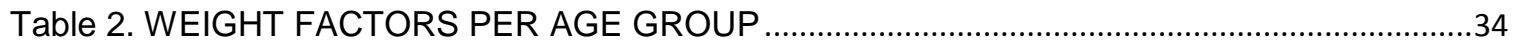

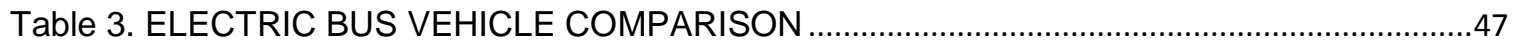

Table 4. PRESENT VALUE AND FUTURE VALUE EQUIVALENCY ……......................................49

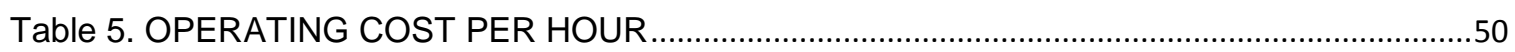

Table 6. OPERATING SUMMARY OF RAILROAD AVENUE ROUTE ….........................................52

Table 7. OPERATING SUMMARY OF TWO ROUTE STRUCTURE ….........................................52

Table 8. PRESENT VALUE COST FOR SINGLE ROUTE STRUCTURE.......................................54

Table 9. PRESENT VALUE COST FOR TWO ROUTE STRUCTURE ..........................................55

Table 10. FULLY-AMORTIZED ANNUAL COST FOR SINGLE ROUTE STRUCTURE ..................56

Table 11. FULLY-AMORTIZED ANNUAL COST FOR TWO ROUTE STRUCTURE ......................57

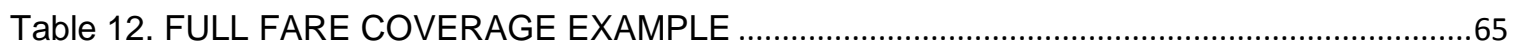

Table 13. DEEP DISCOUNT GROUP PASS EXAMPLE …........................................................6

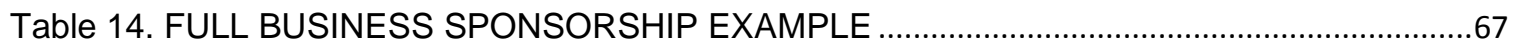

Table 15. RAILROAD AVENUE ROUTE: MILES BETWEEN STOPS ………................................74

Table 16. RAILROAD AVENUE ROUTE: TRANSIT IN-VEHICLE TRAVEL TIME

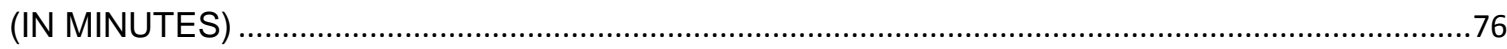

Table 17. RAILROAD AVENUE ROUTE: DIFFERENCE IN TRAVEL TIME BETWEEN

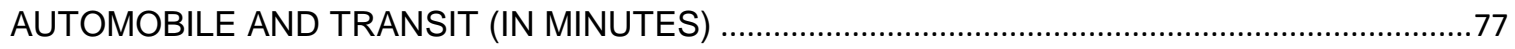

Table 18. RAILROAD AVENUE ROUTE: OUT-OF-POCKET COSTS FOR DRIVING

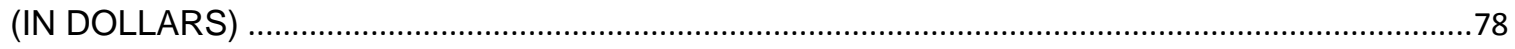

Table 19. WEIGHTED DAILY TRIPS PER PERSON IN EACH AGE GROUP ................................79

Table 20. ALTERNATIVE 1: WEIGHTED DAILY TRIPS OF POPULATION NEAR SHUTTLE

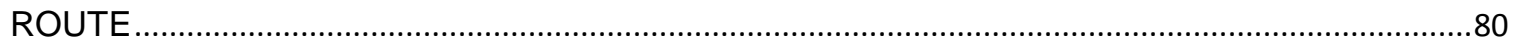

Table 21. ALTERNATIVE 1: FINAL COMPOSITE WEIGHTED DAILY TRIPS TO A DESTINATION 
Table 22. ALTERNATIVE 1: ANNUAL SHUTTLE COSTS MINUS BUSINESS

CONTRIBUTION AND FARES

Table 23. ANNUAL SHUTTLE COSTS MINUS BUSINESS CONTRIBUTION AND

FARES WITH ADDITIONAL BART CONNECTION

Table 24. CENTURY PLAZA ROUTE C: MILES BETWEEN STOPS.

Table 25. CENTURY PLAZA ROUTE C: TRANSIT IN VEHICLE TRAVEL TIME (IN MINUTES) 92

Table 26. CENTURY PLAZA ROUTE C: DIFFERENCE IN TRAVEL TIME BETWEEN

AUTOMOBILE AND 10 MPH TRANSIT (IN MINUTES)

Table 27. CENTURY PLAZA ROUTE C: DIFFERENCE IN TRAVEL TIME BETWEEN

AUTOMOBILE AND 14 MPH TRANSIT (IN MINUTES) . .95

Table 28. CENTURY PLAZA ROUTE C: OUT-OF-POCKET COSTS FOR AUTOMOBILE

TRAVEL (IN DOLLARS). . .95

Table 29. WEIGHTED DAILY TRIPS PER PERSON IN EACH AGE GROUP..... .97

Table 30. ALTERNATIVE 2: WEIGHTED DAILY TRIPS OF POPULATION NEAR

SHUTTLE ROUTE.

Table 31. ALTERNATIVE 2: FINAL COMPOSITE WEIGHTED DAILY TRIPS TO A DESTINATION 101

Table 32. ALTERNATIVE 2: ANNUAL SHUTTLE COSTS MINUS BUSINESS CONTRIBUTION AND FARES. 104

Table 33. CENTURY PLAZA ROUTE L: MILES BETWEEN STOPS .106

Table 34. CENTURY PLAZA ROUTE L: TRANSIT IN VEHICLE TRAVEL TIME (IN MINUTES) . 109

Table 35. CENTURY PLAZA ROUTE L: DIFFERENCE IN TRAVEL TIME BETWEEN AUTOMOBILE AND TRANSIT (IN MINUTES)

Table 36. CENTURY PLAZA ROUTE L: OUT-OF-POCKET COSTS FOR AUTOMOBILE TRAVEL (IN DOLLARS).

Table 37. WEIGHTED DAILY TRIPS PER PERSON IN EACH AGE GROUP.

Table 38. ALTERNATIVE 3: WEIGHTED DAILY TRIPS OF POPULATION NEAR SHUTTLE ROUTE.

Table 39. ALTERNATIVE 3: FINAL COMPOSITE WEIGHTED DAILY TRIPS TO A DESTINATION 
Table 40. ALTERNATIVE 3: ANNUAL SHUTTLE COSTS MINUS BUSINESS

CONTRIBUTION AND FARES

\section{APPENDIX A}

Table A 1. MINIMUM TRAVEL TIME (ROUTE LEVEL EXAMINATION METHOD) .......................127

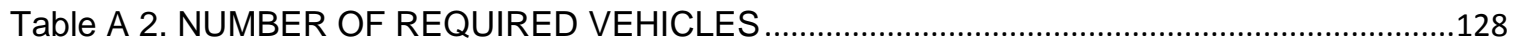

Table A 3. STATION-TO-STATION TRAVEL TIME CALCULATION FOR RAILROAD

AVENUE ROUTE

Table A 4. STATION-TO-STATION TRAVEL TIME CALCULATION FOR CENTURY PLAZA

ROUTE C.

Table A 5. STATION-TO-STATION TRAVEL TIME CALCULATION FOR CENTURY PLAZA

ROUTE L

Table A 6. WEIGHT FACTORS.

Table A 7. WEIGHTED TRIPS FOR 25 TO 44 AGE GROUP 133

Table A 8. WEIGHTED TRIPS FOR 45 TO 64 AGE GROUP .134

Table A 9. WEIGHTED TRIPS FOR OVER 64 AGE GROUP .134

Table A 10. ALTERNATIVE 1: HOUSING UNITS WITHIN 1/4 MILE OF PROPOSED SHUTTLE ROUTES 135

Table A 11. ALTERNATIVE 1: POPULATION OF POTENTIAL TRIP-MAKERS .136

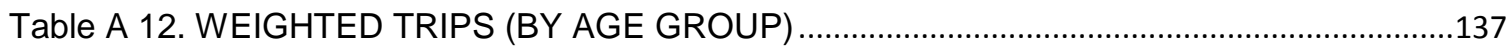

Table A 13. ALTERNATIVE 1: POTENTIAL TRIPS MADE BY POPULATION ..............................137

Table A 14. ALTERNATIVE 1: POTENTIAL TRIPS FROM SENIOR UNITS...................................138

Table A 15. ALTERNATIVE 1: FINAL ADJUSTED POTENTIAL TRIPS MADE BY POPULATION

Table A 16. ALTERNATIVE 2: HOUSING UNITS WITHIN 1/4 MILE OF PROPOSED SHUTTLE ROUTES.

Table A 17. ALTERNATIVE 2: POPULATION OF POTENTIAL TRIP-MAKERS .140

Table A 18. WEIGHTED TRIPS (BY AGE GROUP) 141

Table A 19. ALTERNATIVE 2: POTENTIAL TRIPS MADE BY POPULATION 141 
Table A 20. ALTERNATIVE 2: POTENTIAL TRIPS FROM SENIOR UNITS.

Table A 21. ALTERNATIVE 2: FINAL ADJUSTED POTENTIAL TRIPS MADE BY POPULATION

Table A 22. ALTERNATIVE 3: HOUSING UNITS WITHIN 1/4 MILE OF PROPOSED SHUTTLE ROUTES. 143

Table A 23. ALTERNATIVE 3: POPULATION OF POTENTIAL TRIP-MAKERS ...........................144

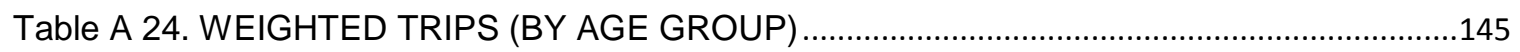

Table A 25. ALTERNATIVE 3: POTENTIAL TRIPS MADE BY POPULATION .............................145

Table A 26. ALTERNATIVE 3: POTENTIAL TRIPS FROM SENIOR UNITS ................................146

Table A 27. ALTERNATIVE 3: FINAL ADJUSTED POTENTIAL TRIPS MADE BY POPULATION 146

\section{APPENDIX B}

Figure B 1. NUMBER OF TRIPS TO DESTINATIONS (BY DAY OF WEEK) ...............................149

Figure B 2. NUMBER OF TRIPS TO DESTINATIONS (BY LOCATION) ....................................150

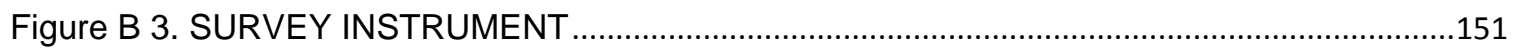

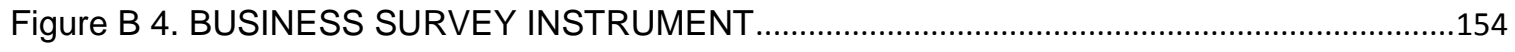




\section{CHAPTER I. INTRODUCTION}

The Circulator Shuttle Implementation Plan examines the feasibility of implementing a shuttle program in Pittsburg, California, leading to a framework for a viable shuttle service system. This project determines the requirements for a shuttle service in the city. It explores whether there is sufficient demand to justify the development of a shuttle service and ascertain the costs involved in a shuttle operation to meet the projected level of demand.

The Institute of Transportation Engineers specifies four steps in the development of major transit projects, of which systems planning is the first phase. The four procedural phases of transportation development projects include systems planning, alternatives analysis, preliminary engineering, and final design (ITE, 2009). The focus here is systems planning, with attention also given to alternatives analysis. In this phase, the general goals and concepts for the system are reviewed. The process of developing proposals involves initial examination of technology, alignments, and costs. Recommendations are made based on an evaluation of costs and benefits.

This study starts with a background review leading into the development of a vision. This is followed by planning of alternatives and concludes with recommendations. A review of literature and best practices informs the planning of the shuttle system. Chapter II: Background examines the principles of shuttle operation. A literature review presents basic operation information, ridership 
influences, and case studies to describe the current state of shuttle planning. This discussion of shuttle characteristics and the environments that support shuttle operation leads to an overview of Pittsburg in Chapter III: Background of the City. Chapter IV: Study Hypothesis and Vision addresses how a shuttle can serve the city and outlines the goals of the project. To carry forth these goals, Chapter V: Study Methodology contains the methods used to determine the demand and cost. Chapter VI: Alternative Plans presents different possibilities in shuttle implementation and describes the operational characteristics of each proposal. The findings from a review of these proposals are discussed in Chapter VII: Findings. To conclude, Chapter VIII: Recommendations and Conclusions describes the shuttle service that would be appropriate for the city today and further steps that can be taken to support future shuttle planning efforts. 


\section{CHAPTER II. BACKGROUND}

\section{IIA. THE ROLE OF SHUTTLES IN TRANSPORTATION SYSTEMS}

Shuttle service can fill the role of a vital transportation connection between different locations. Land use and transportation are inextricably linked. Improving transportation access can stimulate social, economic, and physical development by providing greater connectivity between locations to satisfy a variety of work-related, commercial, and recreational needs. The American Public Transportation Association (2011) found that 59 percent of transit trips were for work, 10 percent were for school, 8 percent were for shopping, 6 percent were for social activities, and 5 percent were personal. Improving access will generate economic activity and promote greater connectivity within the community.

Shuttles are flexible transit systems that provide a number of benefits to the community. The Victoria Transport Policy Institute, an independent research organization dedicated to the development of innovative and practical solutions for transportation problems, describes shuttle programs as services that can carry passengers on short trips along busy corridors; they may connect major activity centers like transit stations and commercial centers (VTPI, 2010). For shuttles, consistent routes and schedules provide a predictable, low-cost transportation service. Shuttles increase transportation options for non-drivers and substitute trips made by automobile. By meeting transportation needs that would otherwise be fulfilled by automobiles, shuttles can contribute to better environmental quality. 


\section{IIB. LITERATURE REVIEW}

The characteristics of shuttle services and operating environments covered in academic literature and transportation planning documents shed light on the requirements for shuttle implementation and the opportunities for shuttles to become an integral transportation component in the community. A discussion of shuttle operations describes why shuttles are used and how they fit into a transportation network. Contracted services are used in numerous transit operations; they provide a starting point for many new shuttle operators and a cost effective part of operations for established transit agencies. Shuttle planning should also acknowledge the influence of different built environments on ridership. This section covers the basic considerations in the initial planning and background examination steps.

\section{SHUTTLE OPERATIONS}

Shuttles fill the gap in larger public transportation networks where the scale of a local transportation connection would not financially warrant implementation, addition, or modification of a fixed-route bus service or rail service. They fulfill the role of the first-mile and last-mile service to provide local transit that complements regional travel access at transit hubs. The small-scaled nature of a shuttle service provides opportunities to better tailor service to local community needs. Adjustments are made more easily with newer, smaller systems. 
Shuttles are often used in smaller operating environments, which brings the benefit of increased accessibility but can also raise some challenges. By their design, shuttles often serve areas of low to medium population density. Ridership for many systems would be inherently lower than expected for many fixed-route bus systems that provide connections to large urban areas. For this reason, smaller entities sometimes contract shuttle services because management can be resource intensive. If cities are the managers of shuttle services, they must be prepared to spend additional time and resources on various issues in planning and administration. ITE (2009) notes some of the disadvantages include greater competition for funding with other municipal services if the shuttle has no distinct funding source. Authority over services may also be limited within city boundaries or may require coordination and negotiation with other governing bodies.

The advantages of shuttle systems are found in their low costs and flexibility. Shuttle services have relatively low startup costs and function on lower operating costs than fixed-route bus services. Routes can be adjusted with greater ease than transit options with fixed infrastructure. A generally smaller workforce allows operations to be conducted with oversight usually from a few administrators. Many components like labor and vehicles can be contracted to third party operators, which allow some work to be outsourced. Due to the low costs and flexibility, shuttle services have been used by a host of different entities, including transit operators, municipalities, joint authorities, and transportation management boards. 


\section{CONTRACTED SERVICES}

Many shuttle operators contract some portion of operation or administration to a transportation provider. Transit agencies contract services when new routes are implemented or when cost reductions are needed. Contracting service is one of the reasons for the lower cost of shuttles compared to other transit options. In California, small-scale transit agencies contract services due to cost savings, avoidance of developing a bureaucracy, and timely delivery of services (Teal, 1985). Flexibility in hours and wages, in addition to outsourcing of maintenance, contribute to lower costs.

Contracting some portion of service is a practice used by some of the more efficient transit agencies, but cost savings vary depending on the size and maturity of the agency. On average, large and medium sized agencies realize greater savings than small agencies. A report on operating costs of small transit agencies by the National Center for Transit Research (2011) found only a small difference between the national average hourly operating costs of directly-operated transit services (\$75.87) and contracted services (\$75.61). The difference in cost savings for small agencies in terms of unit per hour calculations is small - savings are more obvious in larger agencies - but there are savings that may not be reflected in these figures. These savings may include the additional capital expenses, time required for administration, and overhead costs. Both labor and vehicles can be contracted from third party providers. 
Cost savings can be realized through contracting, particularly for larger agencies, but the practice should be evaluated to determine if it will be an appropriate strategy for a particular case. Agencies can see savings of 10 to 40 percent from cost reductions in lower wages, flexible hours, fewer labor rules, and efficiency in maintenance and management through contracting (NCTR, 2011). Kim (2005) found that driver compensation under private operators was 52 percent less and operation cost was 43 percent less than public agencies. Conversely, McCullough, Taylor and Wachs (1998) found that efficiency achieved through better utilization of labor and vehicles can create greater cost reduction than wages. Cost savings from operation costs could be offset by other costs, or a structural reexamination of a transit organization could provide greater savings than simply switching to contracted services alone. Thus, contracting services should be examined on a case-by-case basis.

New agencies can benefit from contracted services more than established agencies but there are tradeoffs between administrative control and service quality. New, smaller agencies can benefit from contracting some administrative and supervisory functions. It is faster to hire drivers and labor disputes are minimized, which reduces some initial administrative work for new agencies (NCTR, 2011). However, administrative costs are still present in the staff time spent coordinating and monitoring contractors. Developing requests for proposals also requires staff time and costs. The major tradeoff between contracted and directly-operated services is related to service quality, cost savings, and extent of 
control. Contracting is an efficient financial solution to start new service, reduce operating costs, and service efficiency. In exchange for efficiency and cost reduction, agencies give up levels of control over operation and loss of control over service quality. Customer service and workforce retention are frequently reported problems with contracted service (NCTR, 2011). The use of contracted services should be evaluated as agencies mature and ridership needs change over time.

\section{RIDERSHIP}

This section covers some of the attributes in transit operating environment that would be applicable to Pittsburg. A study of ridership characteristics that might be inferred by the city's built form offers clues to design an effective service. A description of case study examples that share similar characteristics with Pittsburg's population or urban environment presents some preliminary expectations for shuttles in Pittsburg. Additionally, this review shows how shuttles might fit into future development plans. 
RIDERSHIP IN COMMERCIAL DISTRICTS

The diversity of businesses and mix of multiple opportunities at destinations, particularly in the Old Town area, fits the profile of a good operating environment described by various studies. The draw of commercial or business locations is dependent upon the nature of development, particularly the concentration of different activities. In general, commercial locations can attract riders with a variety of shopping or business establishments. High employment density would not necessarily indicate higher ridership. The type of development, sprawling or compact, would be a factor. The Regional Transportation District found an inverse relationship between high employment density and route performance that may be explained by the prevalence of office parks, which tend to exclude residential or shopping uses (RTD, 2008). Although commercial areas draw visitors, sprawl may negate the attraction of an area. A diverse concentration of commercial properties along transit routes encourages transit use.

Shuttle routes succeed when a system links multiple destinations for a variety of purposes, but only if high population density is associated with areas served by the route. A study of shuttle services in the Boulder, Colorado area found that population density and zero-vehicle households have the strongest correlation to performance over other measures such as median income, employment density, senior density, and youth density (RTD, 2008). The best performing routes connected locations such as the downtown, shopping district, university, high school, and hospital. The route was capable of satisfying different 
trip purposes, which increased its ability to attract a large ridership. Crowlet et al. (2009) make a similar assertion, stating that local densities influence transit use and that land use mixing was of secondary importance. The combination of high population density and routes that connect a variety of destination types results in the most successful routes.

\section{RIDERSHIP AT SENIOR VILLAGES}

To accommodate the growing senior population and maximize the effectiveness and attractiveness of service to older adults, shuttle planning must understand the perception of transit from older residents who may not prefer transit travel but may start to depend on it. Transit frequency and health restrictions were reasons that limited transit use for individuals in a study of common transit issues concerning older adults(Peck, 2010). Individuals who had access to automobiles from family members were less likely to use transit. Peck (2010) found that older adults preferred automobile travel but saw fixed route transit as a viable option. Inadequate transportation access can prevent older adults from performing instrumental activities of daily living, which include visiting friends and family, grocery shopping, and managing medical and pharmacy visits. Providing accessible and easy-to-use fixed-route service would help seniors who do not use paratransit, which is usually reserved for persons with disabilities who cannot use fixed-route transit. 
Transit must accommodate several key needs of seniors: safety, accessibility, and predictability in schedules. Mohammadian et al. (2009) found that safety significantly increases the likelihood to consider transit. Creating clean and organized environments is one method to enhance the sense of safety. Seniors do not make many stops and rarely like to transfer between modes (Mohammadian et al., 2009). Transit should provide fairly direct access to desired destinations. Several highly-rated aspects of service in the Mohammadian study point to the importance of reliability: fixed routes, increased frequencies, brochures with schedules, and real-time information access. In addition to these key features, outreach should be conducted to help introduce seniors to transit use; Mohammadian et al. (2009) found that seniors unfamiliar with transit service did not see it as an alternative to driving or getting a ride from relatives.

The following is a list of barriers to transit use derived from various studies:

Physical barriers:

- Distance

- Auto-dominated infrastructure

- Unfriendly urban streetscapes

- Climactic challenges

- Transit vehicle design

- Overcrowded conditions

Service Barriers

- Convenience and flexibility

- Travel times and destinations

- Connectivity and coordination

- Physical isolation 
- Social isolation

- Economic isolation

- Value and comfort

Perceptual barriers

- Safety perceptions

- Prevalence of crime

Information barriers

- Lack of awareness

- Limited information exchange

- Minimal access to planning process

\section{RIDERSHIP AT TRANSIT-ORIENTED DEVELOPMENTS}

Opportunities to build affordable housing and a variety of retail establishments, identified in the Railroad Avenue Specific Plan, would create an environment supportive of transit service. The Specific Plan calls for improved public transportation linkages to eBART in order to reduce automobile trips to the station (City of Pittsburg, 2009). The development of a shuttle has been proposed in the Phase 4 of Street and Transportation Improvements in the Specific Plan. This service would ideally connect the eBart Station with downtown Pittsburg, Los Medanos College, and other landmarks.

Circulator shuttles are most effective when they serve mixed-use areas that do not require cars to access many destinations (Regional Transportation District, 2008). The Center for Transit Oriented Development (CTOD) finds an increased likelihood of transit use among residents in transit-oriented developments (TODs) compared to other residents in cities. Residents of TODs are 5 times more likely 
to use transit (CTOD, 2009). Residents in TODs also have greater inclination to use transit for reasons of convenience and choice. In an examination of data for the Bay Area as a whole, 19.6 percent who went to work by rail lived within $1 / 2$ mile of a Bay Area heavy rail, light rail, or commuter rail station and 8.6 percent lived beyond a $1 / 2$ mile of rail stations (Cervero, 2007). Although these percentages speak to the strong attraction of rail systems, the reliance on transit carries over to other modes as automobile dependency decreases.

The proclivity towards transit could be a matter of choice; those who choose to live near transit may do so for a number of reasons including the desire to reduce the stress of driving, the desire to save time, and desire to support "green" transportation (Boarnet and Crane, 2001). Therefore, there is reason to believe that, in addition to the generally lower automobile ownership rates, TOD residents would gravitate towards a variety of transit modes. Rail transit fulfills regional travel needs for those who are inclined towards transit travel; local transit options provide the necessary short distance trips for a less automobile-dependent population. "Those with a predisposition for transit-oriented living, the argument goes, conscientiously sort themselves into housing within an easy walk of a rail stop" (Boarnet and Crane, 2001). 


\section{IIC. CASE STUDIES}

A review of several case studies helps establish a direction to examine the shuttle implementation and operation process through the experiences of transit agencies and municipalities. Several key themes are present in many successful shuttle operation examples. An independent report composed by the Transit Resources Center (2004), Community Oriented Transit Best Practices, lists seven themes of importance in a community-oriented transit service.

\section{Matching services to market needs.}

a. Matching community goals and community needs attracts riders by aligning service to their interests rather than the reverse.

\section{Customer service and community orientation.}

a. Regularly talk to passengers.

b. The manager and assistant personally respond to passenger complaints.

c. An employee waits at a stop with passengers at random intervals to check schedule adherence.

\section{Low service delivery costs.}

a. 10-17 riders per hour should be expected unless the location is fairly high in density

i. Community shuttles have a lower demand density by their very nature.

b. $\$ 50-60$ is a reasonable range for per unit operation costs(in 2004 dollars).

c. Competitive contracting and low (less than 20 percent) overhead.

4. Collaborative partnerships to leverage resources and engender local ownership. 
a. Caltrain and Samtrans shuttle programs demonstrate examples of partnership. Although the shuttle is tied to larger regional transit services, a requirement for $25 \%$ employer or city contribution emphasizes ownership and investment by all parties.

b. Bringing different parties with transportation interests together under an umbrella transportation management association pools resources for operation.

\section{Integration with regional transit service backbone.}

a. Mainline connections with bus and rail transit create opportunities for regional travel.

\section{Flexibility to meet needs.}

a. Many successful shuttles grew from somewhat different visions for the service. Growth of a program may come from the need to adapt in changing environments with changing needs.

\section{Entrepreneurial management with leadership of key person.}

a. A key person arranges partnerships and responds to market demand.

\section{OAKLAND FREE-B SHUTTLE}

The Oakland Free-B Shuttle is a service that runs through Oakland's downtown area. The shuttle travels along Broadway Avenue, linking large commercial, business, and entertainment attractions between the downtown and Jack London Square. The system links the Amtrak and ferry station at Jack London Square and the $12^{\text {th }}$ Street and $19^{\text {th }}$ Street Bart stations in downtown Oakland. On weekdays, the shuttle operates from $7 \mathrm{am}$ to $7 \mathrm{pm}$. On weekends, service spans 7am to $1 \mathrm{am}$ (Proulx, 2012). The success of the shuttle can be measured by the nearly 2,600 daily boardings and 1,000 weekend boardings 
(Proulx, 2012). Passengers can ride the shuttle for free. The system is able to fund the nearly $\$ 1$ million annual costs through a set of diverse grants and local revenue sources (Proulx, 2012).

A recent draft white-paper prepared by University of California graduate researcher Frank Proulx (2012) identifies some of the funding sources of the Oakland Free-B Shuttle. Funding includes around $\$ 330,000$ from the TFCA Regional Grant and another $\$ 360,000$ from the MTC Lifeline Transportation Program. An ACTC TFCA Grant has provided $\$ 35,000$ to the program. The contributions of two community benefits districts, which function as assessment districts, have supplied $\$ 32,000$ to the program.

The key factors of Emery-Go-Round's success include

- A supportive commercial operating environment

- A diverse source of funding

\section{EMERY-GO-ROUND}

In the San Francisco Bay Area, Emery-Go-Round is a circulator shuttle in Emeryville. The service is operated by the Emeryville Transportation Management Association (TMA), an entity consisting of employers, developers, and retailers in the city. The TMA acquires its operations funding from an assessment district, the Property Based Business Improvement District (PBID), which provides a stable and continuous source of funding. AC transit provides fueling and washing; SFO Shuttle Bus provides drivers; Penske provides maintenance; and the University of 
California leases bus yard facilities. A number of partnerships contribute to the service (Transit Resource Center, 2004).

Service is provided 357 days per year. Two primary routes operate during weekdays and two other routes operate during the weekend. Ridership in 2003 was 775,392 . The shuttles serve roughly 36 passengers per hour. Peak commute periods account for over 50 percent of the daily boardings, midday boarding accounts for over 25 percent of daily, and late evening accounts for less than 15 percent. About 40 percent of total ridership is based on residential trips (Transit Resource Center, 2004).

Emery-Go-Round has a fleet of 9 vehicles; seven vehicles run during the peak. The model is International 32-passenger buses (Transit Resource Center, 2004). The fleet is partially-owned and partially-leased. The 32 passenger buses are Freightliner buses. The TMA spends $\$ 334,000$ on bus purchases per year (Transit Resource Center, 2004). Operating cost, including contracts, operations, and administration, is $\$ 60.44$ per vehicle per hour.

Emery-Go-Round drivers are contracted from SFO Shuttle. In 2004, drivers started at $\$ 11$ per hour and could rise to a maximum wage of $\$ 14$ per hour. Health care benefits are covered by Teamsters Union. A fueling agreement with AC Transit significantly lowers fueling expense because AC Transit has volume exemption and exemption from the gas tax. Bus washing with AC Transit removes the cost of acquiring a wash rack/ drainage system. 
Emery-Go-Round started as an employer shuttle to BART that adjusted to the changing environment. The shuttle provides transportation connection to residents and large employers on the Chiron office park, the Pixar campus, and the Bay Street Retail shopping hub. It started as a service for visitors going to the Bay Street Retail area then provided service to the growing residential base. The shuttle became a multiuse transportation alternative.

The key factors of Emery-Go-Round's success include

- A customer focus, providing convenient service that takes people where they need to go

- Partnerships to generate stable funding and reduce costs

- Support of the service from retail establishments

- Flexibility to adjust to changing needs

\section{MENLO PARK COMMUNITY SHUTTLE}

The City of Menlo Park sponsors the Menlo Park Community Shuttle. The City started the service in 1998 as a free midday transportation service. The service is operated at lower speeds to accommodate the needs of its senior ridership. It takes passengers from senior housing to shopping and amenities. Menlo Park Shuttle benefits from the opportunity to form connections with Menlo Park Caltrain, an important transit hub in the area. The shuttle provides links to Safeway, medical clinics, the library, senior centers, and recreational facilities. 
A variety of sources funds the shuttle: currently local sales tax measures and BAAQMD awards, and previously redevelopment money. The City chose to use local money to maximize funding productivity. Funding sources in the $2004 / 2005$ budget came from the City's redevelopment money $(\$ 55,000)$, BAAQMD TFCA $(\$ 35,000)$, and Measure A, a San Mateo County tax $(\$ 39,375)$, for a total of $\$ 129,375$. The City applies for funding from this measure each year. The annual budget for the shuttle was $\$ 123,214$ in 2003 . The contractor cost, including vehicles, is $\$ 44.78$ per hour due to contractor discounts. (Transit Resource Center, 2004)

The service has consistent headways at the same time for each route, which provides predictability. Initially, passengers were confused by the 3 bus service and the scheduling. Shuttles are planned around a speed of 9 miles per hour. This speed accounts for wheelchair boarding and package loading.

Ridership productivity increases came from two actions. An image improvement, in which buses were painted with Menlo Park Shuttle, and service promotion brought an increase of passengers from 53 to 95 passengers per day. An increase of 4 passengers per hour to 9.7 passengers per hours resulted from fewer service hours and more passengers on buses.

Key principles of Menlo Park Community Shuttle include

- Adopting a customer-oriented approach

- Allowing flexibility to change

- Operated through the City with a variety of funding sources 


\section{CHAPTER III. BACKGROUND TO THE CITY}

Pittsburg is a city of over 63,000 residents in the San Francisco Bay Area. Many workers commute from this suburban community to different employment locations in the Bay Area. In 2010, over 86 percent of all residents drove to work; 67.3 percent of all residents drove to work alone. About 8.5 percent of residents traveled by transit (Census, 2010).

Figure 1 highlights many key locations in Pittsburg. Land uses on the map show the types of activity around these points. Commercial nodes in the northern, southern, and eastern parts of the city are marked with a green star. Among them are the Old Town area, Atlantic Avenue Shopping Center, and Century Plaza Shopping Center. City Park and the Civic Center are public facilities located around the center of the city. Marina Vista Elementary School, Pittsburg High School, and Los Medanos College are near major roads in the city. Senior housing units are also marked on the map. The potential site of the eBART station is centrally-located in the city. Around the station, the Railroad Avenue Specific Plan has proposed higher-density, transit-oriented development in a Priority Development land use zone. The locations on the map show that these areas of interest lie along linear axes that can be linked by a potential transit connection. 


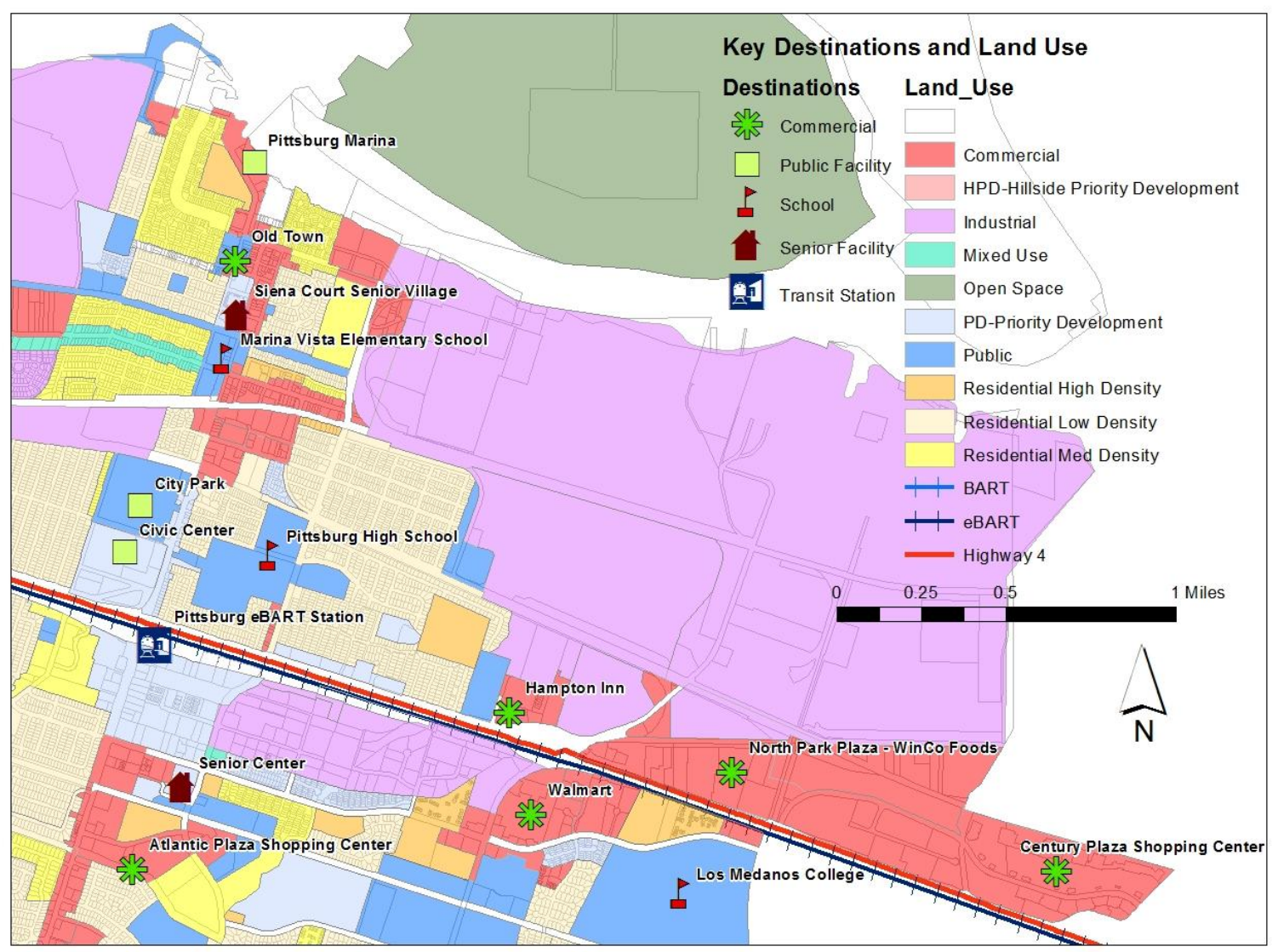

Railroad Avenue is one of the main corridors in the city. The street provides transportation access to government offices, commercial centers, and residential places. The compact urban form of the Old Town area of Pittsburg and the planned transit-oriented development in the Railroad Avenue Specific Plan area reflect the type of development that promotes walking, bicycling, and transit use. However, other areas of the city, even along Railroad Avenue, exhibit a less dense, more automobile-oriented form. A potential shuttle system would connect a diversity of development types around the city. 
The Old Town area is the historic downtown that has been revitalized after extensive redevelopment. In addition to the rehabilitation of culturally-significant structures, a high-density mixed-use project, the Vidrio, and a new senior village, Siena Court, have been constructed. General Plan Goal 5-G-4 establishes a goal of 7000 residents in the downtown area to support commercial uses (City of Pittsburg, 2009). The design of Old Town encourages pedestrian travel. Restaurants and retail buildings are set side-by-side to form an unbroken façade of commercial activity. Outdoor dining and large storefront windows create a welcoming environment for pedestrians. The attractive atmosphere of Old Town is enhanced by the many events hosted in the area's central plaza.

Several public facilities are located near Railroad Avenue. City Hall, the Contra Costa County Courthouse, and the Pittsburg Library are located at the Civic Center, which is bounded by Davi Avenue, Railroad Avenue, Civic Avenue, and State Route 4. Three schools are within a half-mile of Railroad Avenue: Pittsburg High School, Marina Vista Elementary, and St. Peter Martyr School. Although Los Medanos College is not on Railroad Avenue, an east-west shuttle route can bring students from the central Pittsburg area to the institution.

The Railroad Avenue Specific Plan has established a vision for the priority development area adjacent to the future eBART station. A transit-oriented development has been proposed for the area. The transit village sub-area encompasses 134 acres bounded by State Route 4, Harbor Street, East Leland Road, and properties west of Railroad Avenue. High- and medium- density 
residential buildings will be buffered by community commercial uses fronting Railroad Avenue (City of Pittsburg, 2009).

Atlantic Plaza and Century Plaza are large retail shopping areas in the city. The Atlantic Plaza Shopping Center is located at the intersection of Railroad Avenue and Atlantic Avenue. Walgreens, CVS Pharmacy, and Food Co provide daily retail needs for residents. The city's senior center is also located in the vicinity of the shopping center. Century Plaza is a large shopping plaza along Century Boulevard. The site features Target, Toys R' Us, Ross, Burlington Coat Factory, and Maya Theater as major anchor stores and attractions. It is over 3 miles east of Railroad Avenue. Other shopping areas in the eastern part of Pittsburg near the Century Plaza area include Walmart and North Park Plaza, which is anchored by the WinCo grocery store. Automobile access is the primary means of reaching the city's large shopping areas.

Tri Delta Transit, the eastern Contra Costa County transit provider, provides bus service through Pittsburg. Many bus routes operate along segments of Railroad Avenue but no routes on Railroad Avenue run through the Old Town Area. Opportunities are also present to plan quicker, more direct east-west transit routes to connect the center of the city to the shopping areas at the edge of the city. Pittsburg/Bay Point BART is accessible by bus service and automobile, although the station area has limited parking. An extension of BART service via the eBART system expands the regional rail service to Railroad Avenue and a shuttle service along Railroad Avenue would provide an instant local connection. 
Transit along Railroad Avenue, a major corridor in the city, does not currently provide a direct connection among many of the city's major nodes: the commercial establishments in the growing Old Town area, the major employment location in the Civic Center, and shopping centers in the southern and eastern parts of the city. Fast, car-free transportation service between these locations could potentially attract more people to commercial areas, improve transportation options for residents and visitors, and reduce externalities related to automobile travel. Upon completion, the eBART station on Railroad Avenue also presents an opportunity to establish a shuttle system that will connect residents to regional transportation and visitors into major locations around the city. Residents in the senior complex around the Old Town area and future residents in the transit-oriented development housing projects near the proposed eBART station will also be able to reduce dependency on cars. Pittsburg has the opportunity to manage transportation demand, promote more travel options, and bring about various citywide and individual benefits. "A shift away from car dependence is done by creating mode choice, enhancing services and products, lowering individuals' costs, and reducing societal costs" (Sperling and Gordon, 2009). 


\section{CHAPTER IV. STUDY HYPOTHESIS AND VISION}

\section{IVA. SERVING TRANSPORTATION NEEDS}

Transportation needs may soon become apparent in the Old Town area due to the increase in commercial interest and general development near this downtown node. With a burgeoning downtown area that has seen an increase in businesses and residential units over the past decade, Old Town is set to become one of the major draws in Pittsburg, as an area of shopping, dining, and entertainment and as a place of residence. The number of trips through the Old Town area will increase as a result. The two-lane segment of Railroad Avenue that leads into the Old Town will have to accommodate the increase in trips, but factors such as the limited space to expand parking and the slower vehicle travel speeds through the Old Town area may lead to congestion issues if there is a heavy dependence on automobile trips. Transportation needs around the Old Town area will continue to increase as interest in Old Town grows.

\section{IVB. IMPROVING ACCESSIBILITY}

With different shopping, dining, and entertainment opportunities available in distinct nodes around the City, shuttle connections could provide a car-free alternative to those with limited access to cars. A direct transit service between major destinations provides the senior population with greater mobility options. Senior-oriented travel destinations can be integrated into a fixed-route system, where travel from the Siena Court senior apartment complex in the Old Town area 
can be connected to the senior center in the Atlantic Plaza area. Seniors and other travelers who have less automobile access would be connected between the different shopping opportunities, linking the small commercial retail establishments in Old Town with the everyday shopping needs provided in Atlantic Plaza and larger retail shopping options in Century Plaza.

\section{IVC. MEETING TRAVEL DEMANDS THROUGH TRANSIT}

Tri Delta provides valuable intercity public transportation service, however, there is potential to introduce a fast, more locally-focused transportation service to meet transportation goals. Existing transit routes that operate within the City cover a large area. As a result, routes are long and meandering. Although there is some overlap between existing bus routes and portions of proposed shuttle routes, the shuttle service would provide faster and more direct service between important nodes in the city and fill gaps of service in the existing bus system (Figure 2). Several routes $(392,393,394)$ only provide weekend services. There is currently no transit service that travels through the Old Town area along Railroad Avenue. Upon completion of the eBART station, the shuttle can also provide a more direct connection between the transit hub and Old Town. The proposed east-west route will create a more direct connection between the Civic Center and Century Plaza.

The shuttle aims to provide a faster complement to transit service through shorter headways and routes that make stops at select locations in the City. The kinds of trips provided by Tri Delta would not be completely similar to trips from the 
proposed shuttle service. The average trip length is between 6.0 and 6.8 miles for Tri Delta passengers (ECCTA, 2008). The longest proposed shuttle route only extends 3.6 miles in one direction. Where Tri Delta provides coverage over a large area, a potential shuttle can bring more direct trips to certain locations, which would encourage greater overall transit use. Increased transit use would contribute to City goals in reducing congestion, minimizing parking demand, and decreasing greenhouse gas emissions. Furthermore, a shuttle service is identified in the plans as a possible transportation improvement solution for future transit-oriented developments along Railroad Avenue (City of Pittsburg, 2009). This study does not preclude the operation of the proposed shuttle service from Tri Delta. It is presented to identify the possibilities in shuttle operation such that any entity - the City, Tri Delta, or another party -has a direction to implement service.

Figure 2. POSSIBLE SHUTTLE ROUTES CORRESPONDING WITH TRIDELTA TRANSIT

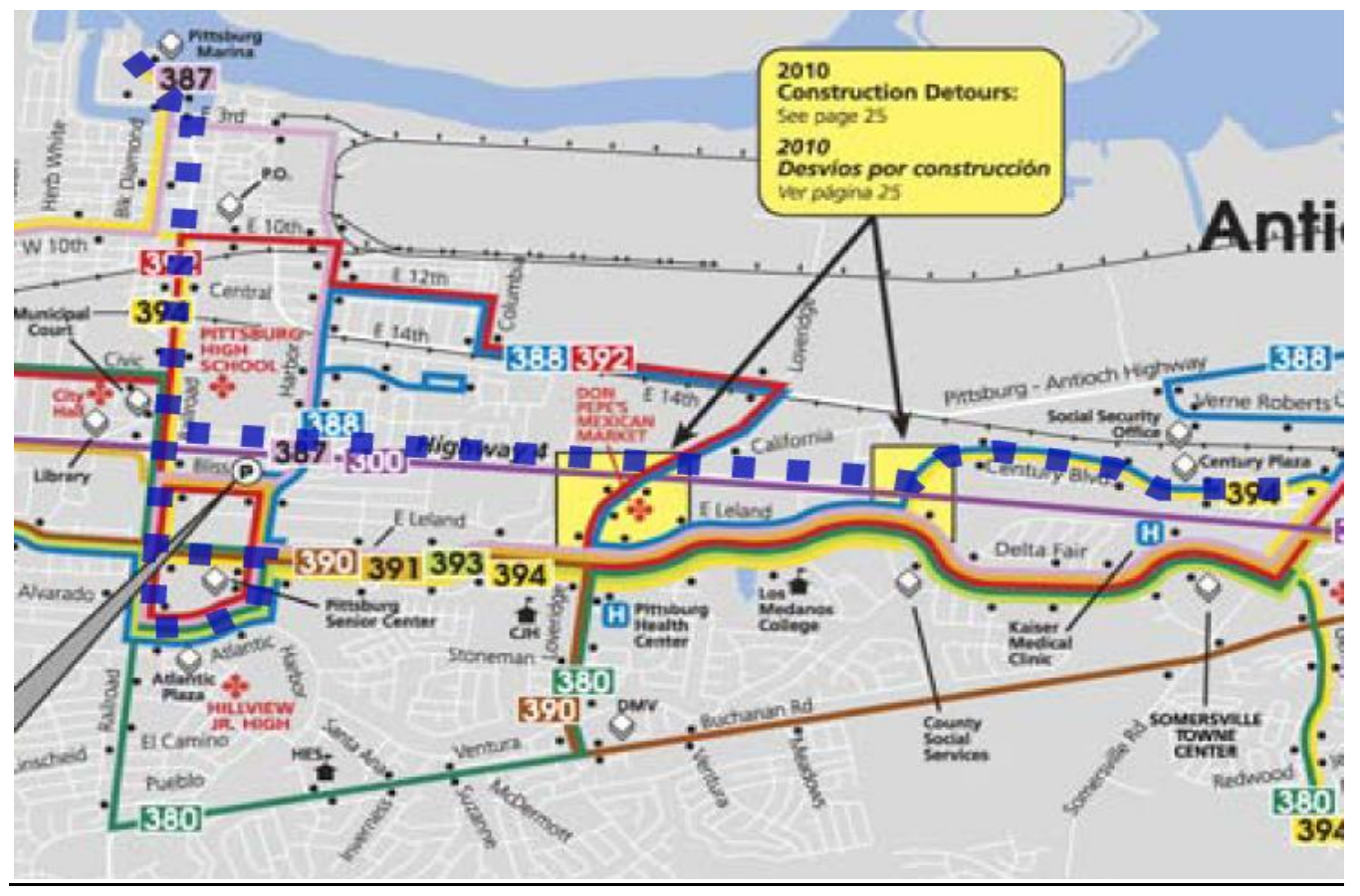




\section{IVD. REDUCING EXTERNALITIES ASSOCIATED WITH AUTOMOBILE}

\section{TRIPS}

\section{CONGESTION}

Limited availability of parking causes drivers to circle around adding to vehicular traffic activity and congestion. A combination of high-density housing, a growing commercial base, proximity to two schools, and a center for community events in Old Town can create demand for vehicle travel on the road network. Without alleviation of road capacity and parking demand through alternative transportation options, the Old Town area may become impacted at peak times throughout the day. The high presence of vehicular traffic would detract from the pedestrian environment and bring health and safety concerns.

\section{PARKING}

As densities and commercial development continue to increase in the Old Town area, parking supply will be in higher demand. It will be difficult to locate areas to accommodate the spaces required for anticipated demand. Creating alternative transportation options provides one method to shift travel demand to other modes. A reliable alternative to car travel can prevent spillover of parking into places that were not designed to meet the parking demand. 


\section{EMISSIONS}

Decreasing dependence on single occupant vehicle trips is a strategy that is compatible with the City's commitment to addressing air quality and climate change issues. Nationally, transit riders save 4.16 billion gallons of gasoline per year and prevent the release of 37 million metric tons of carbon dioxide (APTA, 2011). A shuttle system aligns with the City's desire to reduce carbon emissions through sustainable transportation alternatives.

\section{SAFETY}

Encouraging the use of transit can improve safety on the road. Reducing the number of vehicles on the road decreases exposure to accidents. APTA (2011) reported fewer deaths for transit riders per million miles traveled than for motorists between 2003 and 2008. On transit buses, 0.05 deaths occurred per 100 million passenger miles, while 1.42 deaths per 100 million miles occurred on motor vehicles. Traffic accidents contribute to large losses. Some estimates for the cost of accidents by category are mentioned by the Institute of Transportation Engineers (ITE, 2009), including:

- Fatality: $\$ 3,610,000$

- Incapacitating injury: $\$ 181,000$

- Non-incapacitating evident injury: $\$ 46,200$

- Possible injury: $\$ 22,000$

- Property damage only: $\$ 2,000$ 


\section{CHAPTER V. STUDY METHODOLOGY}

\section{VA. BACKGROUND RESEARCH}

\section{DEMOGRAPHIC INFORMATION}

A look at the distribution of the city's population by key demographic characteristics can shed light on some of the transportation needs. In particular, travel needs may differ between age groups. Figure 3 shows the population pyramid as of 2010 (Census 2010).

Figure 3. POPULATION DISTRIBUTION BY AGE AND SEX

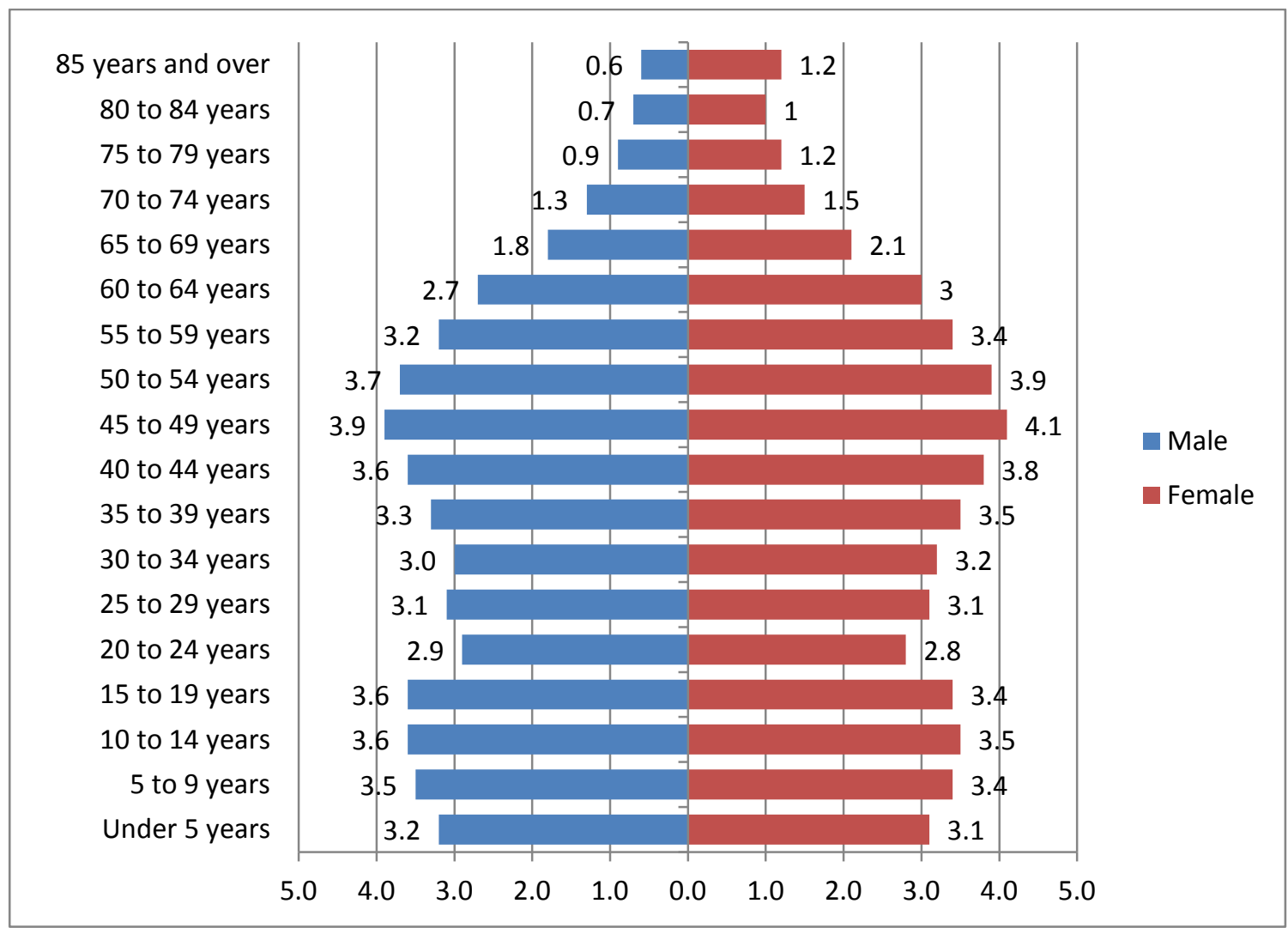

Source: Census, 2010 
Comparing mode shares with the population distribution provides a general idea of transit use in the community. The American Community Survey 1 -Year estimate for 2011 describes the travel characteristics of Pittsburg residents. 70.3 percent drove alone, 15.9 percent carpooled, 8.2 percent took public transportation, 0.3 percent walked, 2.2 percent used other means, and 3.1 worked from home (Census, 2011). These numbers are comparable to numbers found in the 2010 decennial census, where 86 percent of people traveled by automobile and 8 percent of residents used transit (Census, 2010). Table 1 summarizes population distribution data found in the 2010 decennial census. The transit commute ridership can be expected to be around 8 percent, which means transit should be an important commute service to the 33,000 residents between ages 25 and 64 , or 53 percent of the 63,000 Pittsburg residents. Additionally, mobility options for older residents - about 8.5 percent of the population - can be increased through more extensive transit service. Of the 38.2 percent of residents under the age of 25 , a useful transit service would connect a variety of locations, including the schools in the Old Town area and Los Medanos College.

Table 1. POPULATION DISTRIBUTION

\begin{tabular}{|l|r|r|r|}
\hline & \multicolumn{1}{|l|}{ Male } & \multicolumn{1}{l|}{ Female } & \multicolumn{1}{l|}{ Total } \\
\hline Under 25 & 19.4 & 18.8 & 38.2 \\
\hline 25 to 44 & 14.3 & 14.6 & 28.9 \\
\hline 45 to 64 & 11.4 & 12.8 & 24.2 \\
\hline Over 64 & 3.5 & 5.0 & 8.5 \\
\hline Total & 48.7 & 51.3 & \\
\hline
\end{tabular}




\section{POTENTIAL RIDERSHIP SURVEYS}

A survey process was used to gauge interest from the people of Pittsburg to determine the needs and ridership levels that shuttle planning must take into account. A combination of online surveys and in person interview surveys was used to gather an indication of interest in a shuttle service.

This process began with an examination of general citywide sentiments by providing residents with the ability to access the survey online though a website created specifically for this study: www.pittsburgshuttle.weebly.com. The website provided basic information about the project to residents and linked residents to an online survey created through SurveyMonkey, the survey development and response collection tool. The City of Pittsburg spread awareness for this website through a notice in the City's water bill. In addition, flyers were posted or distributed at various locations around the city. This survey process provided the chance to comment on the shuttle system to as many residents as possible.

Physical surveys were administered at various locations around the city. Field intercept surveys were conducted at several key activity locations: Old Town, Civic Center, and Atlantic Plaza. The survey was also distributed to employees at the Civic Center to gauge interest in the shuttle as a mode to serve their commute or midday travel needs relating to business, errands, or lunch. Surveys were made available at the senior center. 
The surveys provided the first sentiments about shuttles gathered directly from the public, but as with any survey, results should be interpreted with consideration of their limitations. Surveys are collected only with permission from the respondent, which means there is no way to understand the perspective of those who chose not to voice their opinions. However, there is little reason to believe that the travel behaviors of those who answered the survey would be vastly from those who chose not to participate. Since this survey measured the importance of short trips to local commercial destinations, the basic local shopping needs should have been captured effectively. In later sections, the results of ridership projections based on these surveys are also compared against general standards for transit performance to ensure that results are within reasonable ranges. To better interpret survey results, steps are taken to fit the survey results to population characteristics.

RESULTS FROM SURVEY OF RESIDENTS, EMPLOYEES, AND VISITORS

The results of the survey, weighted against the age distribution of the population according to the 2010 Census to normalize responses, are shown below. Extrapolating travel characteristics from the survey required weighing survey answers based on the proportional composition of the respondent's age group in the population. The method provides a way to limit the effects of overemphasizing or underemphasizing the answers of an age group relative to their actual proportional makeup of the population. The weighted factors are shown in Table 2. 
Table 2. WEIGHT FACTORS PER AGE GROUP

\begin{tabular}{|l|r|r|r|}
\hline & Survey & Census $^{*}$ & Weight Factor $^{* *}$ \\
\hline Under 24 & $7 \%$ & $38 \%$ & 5.35 \\
\hline $25-44$ & $31 \%$ & $29 \%$ & 0.94 \\
\hline $45-64$ & $48 \%$ & $24 \%$ & 0.50 \\
\hline Over 64 & $14 \%$ & $9 \%$ & 0.60 \\
\hline Total & $100 \%$ & $100 \%$ & 1.00 \\
\hline
\end{tabular}

*Source: Census 2010

** Weight Factor $=\frac{\text { Census }}{\text { Survey }}$

Information about the morning commute gathered from the survey are weighted then aggregated to represent the population. Time of morning departures is shown in Figure 4. About a third of trips began between 6 am and 7 am; another third of trips began between 7 am to $8 \mathrm{am}$. About 70 percent of travelers made their trips in these two periods. Therefore, shuttle service should start before $8 \mathrm{am}$ to meet this significant demand. The purpose of these morning trips is shown in Figure 5, and the primary mode of travel is shown in Figure 6. Nearly 70 percent of trips were for the work commute, which roughly corresponds to the 65.6 percent of the population in the labor force according to the 2011 American Community Survey (Census, 2011). About a quarter of trips are shopping or dining trips, which shows trips to commercial locations comprised a sizeable proportion of morning trips. The primary mode for the commute is the single occupant vehicle (Figure 6). People who primarily drive alone capture 64 
percent of the commute share, which is somewhat lower than the estimate of 70 percent in the American Community Survey (Census, 2011). Bus ridership has a 12 percent commute share, which is higher than the estimated 8 percent in the American Community Survey (Census, 2011). Although this sample has a slightly higher preference for transit use than expected based on estimates, the small difference in mode choice should not have a significant effect on the need to make daily trips around the city. Most morning trips are made in Pittsburg (Figure 7). Automobiles access is available to most people (Figure 8). Daily trips to key locations around Pittsburg are shown in Figure 9. Given a shuttle system that provides transportation access around Pittsburg, respondents generally accepted fares of up to one dollar (Figure 11).

Figure 4. TIME OF MORNING TRIP DEPARTURES

\section{Time of Morning Trip Departures (Weighted)}

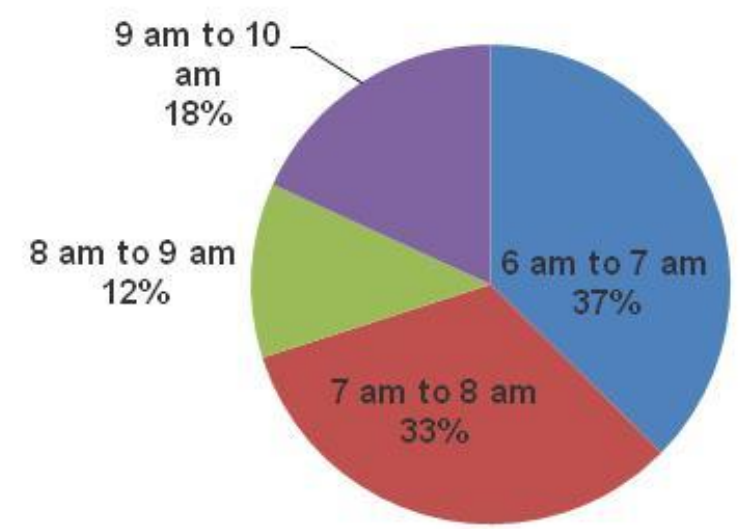


Figure 5. PURPOSE OF MORNING TRIP

\section{Purpose of Morning Trip (Weighted)}

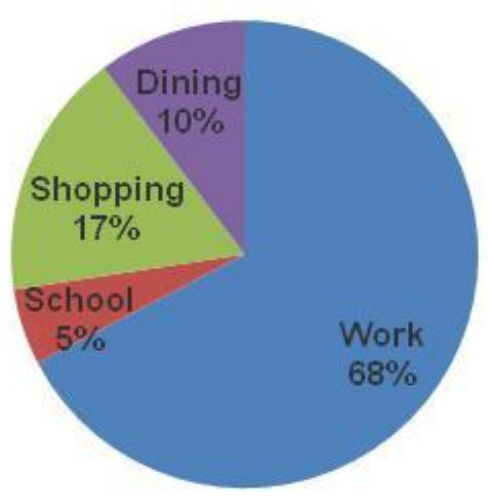

Figure 6. DESTINATION OF MORNING TRIP

\section{Destination of Morning Trips (Weighted)}

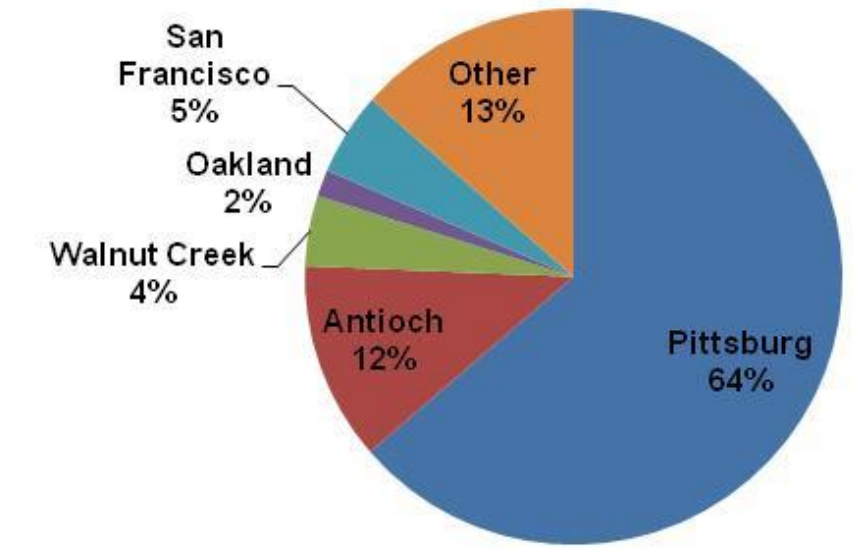


Figure 7. ACCESS TO AUTOMOBILE

\section{Access to Automobile (Weighted)}

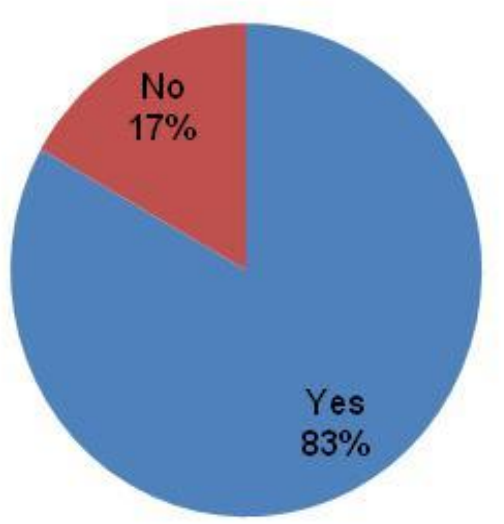

Figure 8. PRIMARY MODE OF TRANSPORTATION

\section{Primary Mode of Transportation} (Weighted)

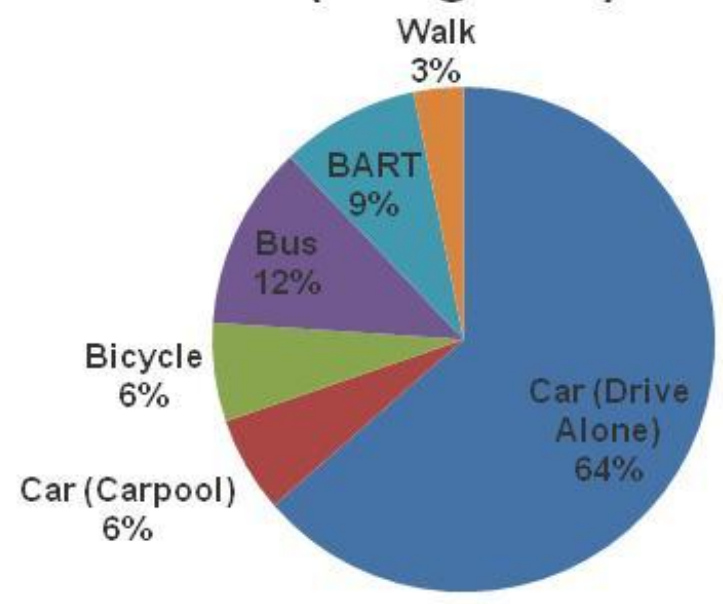


Figure 9. DAILY TRIPS TO A DESTINATION PER PERSON BY AGE GROUP (WEIGHTED)

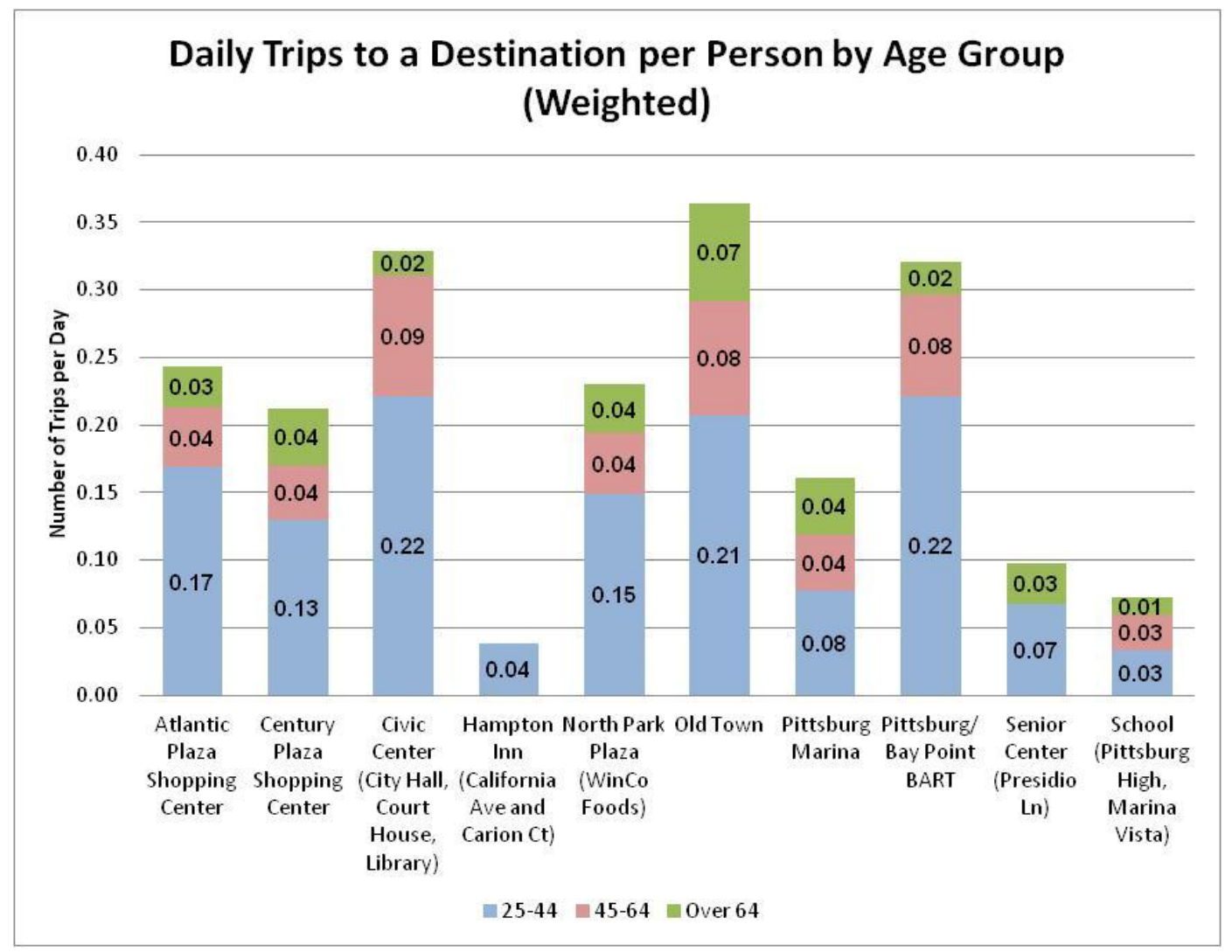

Figure 10. LOCATIONS OF SHUTTLE STOP INTEREST

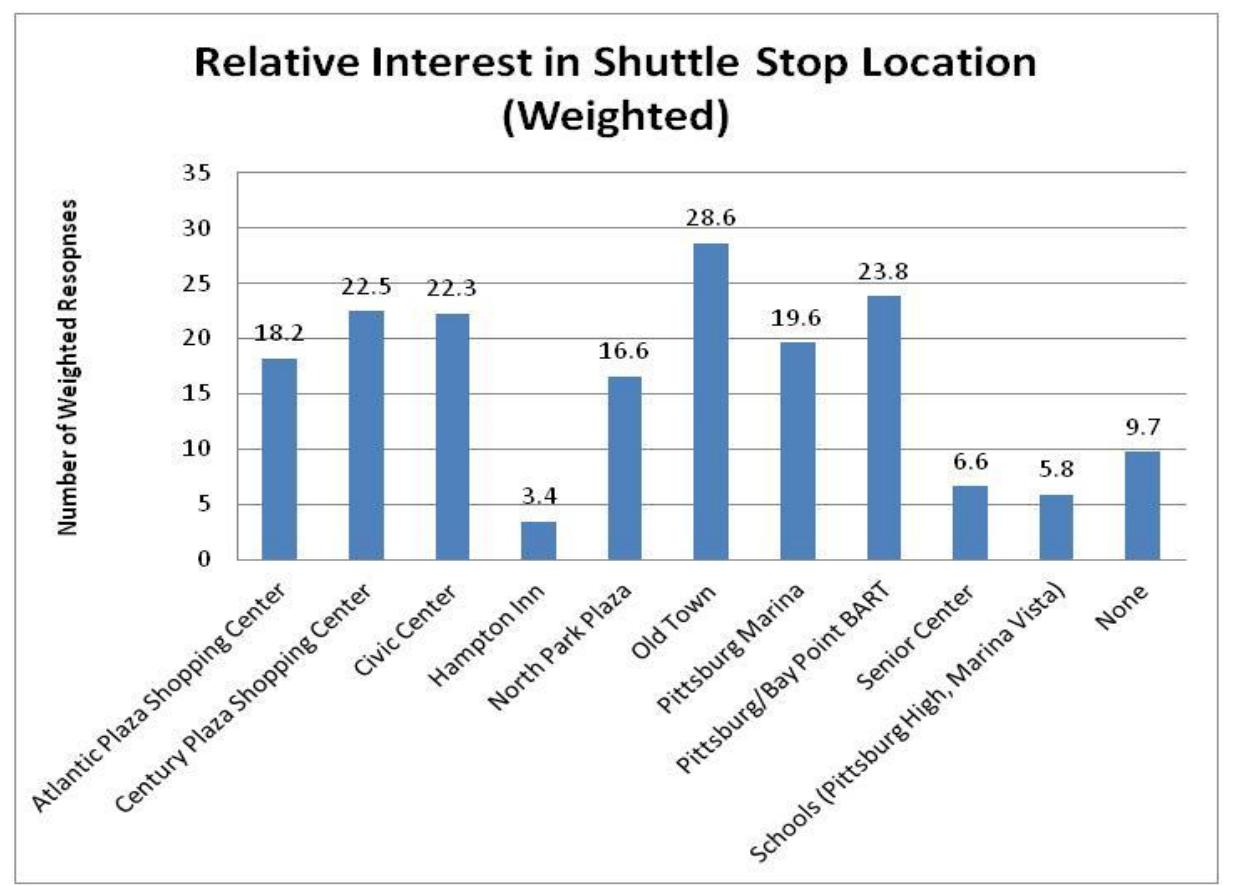




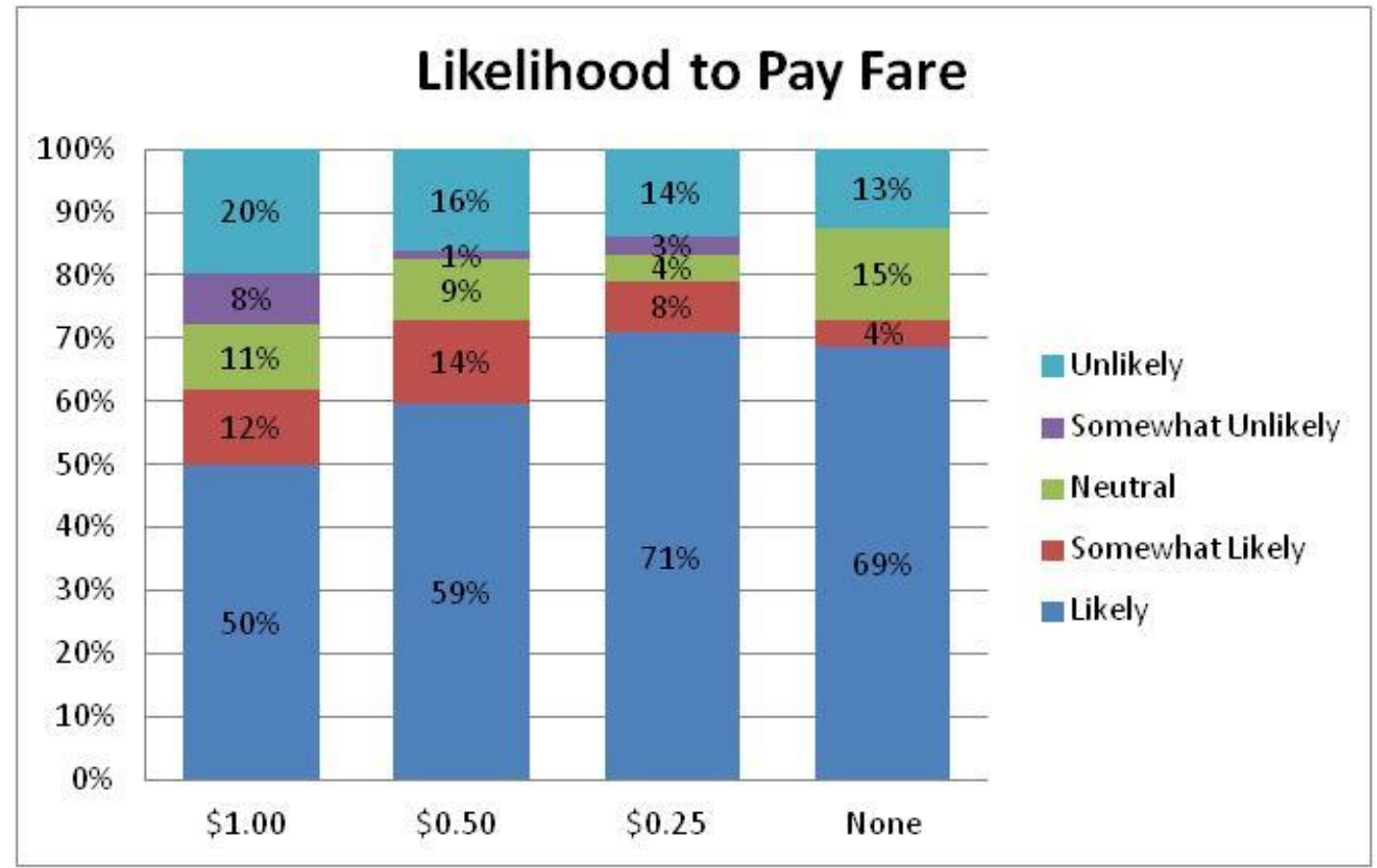

RESULTS FROM A SURVEY OF BUSINESSES

Business owners along Railroad Avenue and Atlantic Plaza were also surveyed. Respondents could provide responses on physical surveys specifically designed for businesses. A digital notification for this survey was also emailed to businesses along major commercial corridors, many of which correspond to the proposed routes. Response is minimal in this survey, but some insights are gathered. Of those that seemed interested in the shuttle, \$25 per month (or approximately $\$ 1$ per day) is an acceptable contribution. The Old Town connection is a link that business owners would like to see. The general sentiment gathered from the responses and from conversations with business owners is that shuttles could be an asset to promoting commercial activity but financial contributions to the program would not be well-received at this time. 


\section{VB. EVALUATION OF DEMAND}

Ridership along a transit route can be estimated using a variety of methods, but is especially difficult for new services. Without base ridership numbers or observed ridership trends from previous years, projections of potential passengers would have to rely on a collection of information and modeling techniques from other sources. This study uses well-established calculations and equations from national publications, like the Institute of Transportation Engineers' Transportation Planning Handbook, together with journal articles, peer-reviewed papers, and academic literature from publications like the Transportation Research Record, to arrive at some basic calculations for new ridership.

\section{RIDERSHIP AND TRIP CALCULATION}

Average daily trips for the alternative were calculated by 1) using survey data and applying weight factors to normalize the survey's population distribution with the actual population distribution; 2) determining the population of potential transit riders in the route service area; and 3) making further adjustments to account for special populations. The daily ridership calculations are discussed in greater detail in each of the alternative plans.

First, the basic calculation is made for weighted daily trips to a destination per person in a particular age group. The calculation takes the total weekly travel demand for each location in each age group, and then divides this total by the 7 days to get the average daily travel demand for each age group. This result is then 
multiplied by each age group's appropriate weighted factor to account for the disparity in population proportions between the sample and the actual population.

$$
W(\text { Weighted Daily Trips })=\frac{T}{7} * W f
$$

Where,

$W=$ Weighted Daily Trips $=$ weighted daily trips to a destination per person in an age group

$T=$ total weekly number of trips made to each destination by age group

$R=$ number of respondents per age group

$W f=$ weight factor: 0.94 for ages $25-44,0.50$ for ages $45-64,0.60$ for over 64 (Table 2).

Second, the results are further modified to determine the population of potential transit riders based on the previously calculated weighted daily trips. Daily trips for each age group/ population pair are multiplied by the total population of that age group along the proposed shuttle route. Total population along the proposed route is calculated as the number of housing units within $1 / 4$ mile of the route multiplied by 3.22, the average household size in Pittsburg (Census, 2010).

In calculating the number of trips from one location to another location, it is important to exclude the proportion of the population for which the origin and destination of trips are within the same area. For instance, if someone wants to go to Old Town, the potential ridership for this trip is the total potential ridership population minus the Old Town resident population. It would be unreasonable to expect many people from Old Town to make a transit trip to another place in Old Town when it would be easier to walk. 


$$
L=P *[H *(U-A)]
$$

Where,

$L=$ population of age group living within $1 / 4$ mile of a shuttle route that would make trips

$P=$ proportion of the population in age group

$H=$ average household size in Pittsburg (3.22)

$U=$ total housing units within $1 / 4$ mile of shuttle routes

$A=$ total number of units in area of trip origin

Third, additional adjustments are made to account for factors not captured in the previous step. The number of units in senior complexes (Siena Court and Stoneman Village 1 \& 2) are not multiplied by the household average because they have unique living arrangements. Instead, these units are counted as one person per unit and average daily trips from the age group "Over 64" (from Figure 9) are multiplied by the number of units. These trips are added into the aggregate of trips calculated from the previous step.

Finally, the total trips to a destination produced by the population in each age group are then multiplied by a factor of 0.04 , the proportion of trips made by transit for the purposes of shopping and commercial activities (HBShop) as determined by the Contra Costa Transportation Authority (CCTA, 2003).

$$
T=\operatorname{HBShop}(L * W)
$$

Where,

$T=$ potential trips to a destination

HBShop $=$ Home-based-shopping trip made by transit (4 percent of trips) *

$L=$ population of age group living within $1 / 4$ mile of a shuttle route that would make trips

$W=$ weighted daily trips by age group

*Source: Contra Costa Transportation Authority (2003) 
For the sake of a more conservative and carefully calculated ridership projection, some omissions are made due to the uncertainty of present conditions or survey responses. The ridership interested in the BART connection is also omitted for now due to the unknown status of the eBART station on Railroad Avenue. In collecting travel information, respondents under the age of 24 composed a small proportion of the sample compared to their distribution in the actual population. To limit the impact of overstated importance of certain trips based on a fairly small sample group, trips are given a zero value. In reality, the shuttle could be utilized by students of the schools in the Old Town area and those who wish to access the Railroad Book Depot in the Old Town area or the library near the Civic Center. Other destinations excluded in the final trip consideration are the senior center and schools. These locations are difficult to estimate based on surveys because these places have few responses, which would increase the chance of overestimation or underestimation due to their accommodation of very specific populations. Furthermore, these locations are close to other locations that are represented: the senior center is near Atlantic Plaza Shopping Center and the schools are near Old Town. These nearby locations could serve as proxies to trips that would be made to the senior center and schools. Removing trips to these two locations from the final ridership calculation is done to limit the effects of less reliable data. Calculation of ridership in these alternatives did not include the additional transit-oriented development units in the priority development area of the Railroad Avenue Specific Plan. These units would not be built in the near 
future. Although they are absent from current analysis, future projections should include these units once their development has been approved. The roughly 1845 units expected in the area - noted in the Railroad Avenue Specific Plan - will be home to a population that may have particular utility for alternatives to the automobile. The ridership calculation process takes a more conservative approach in projection of transit users. The actual ridership values are likely higher than those that are projected in this study due to some current limitations.

\section{ALTERNATIVE METHODS OF CALCULATION}

The absence of data or restricted access to certain methods led to the development of a ridership projection method created just for this project. In the end, the destination focused and smaller scale focus on key destinations in this model may be more fitting than the larger scale projection methods that could have been employed. However, alternate projection methods can also be employed to compare results.

Ideally, a regional transportation model would be employed to estimate travel between different zones in the city, but this study uses a more destination-focused project method in the absence of larger transportation analysis zone models. The Contra Costa Transportation Authority (CCTA) maintains a model for Pittsburg and surrounding jurisdictions that is used to estimate trips between different areas of the city divided into transportation analysis zones. CCTA should maintain information on trip generation, trip 
distribution, and friction factors that provide a way to estimate travel between the transportation analysis zones in the city. This information is not generally made available to the public. Although another set of projections using the transportation analysis zone model would have provided an additional source of reference, the methods employed in this study for ridership projection and travel time calculations provided a greater focus on the short travel distances along the proposed shuttle corridors.

Another method of calculation to estimate latent demand is to acquire the demographic information from the area served by transit. This method determines likelihood of transit usage by determining the proportion of the population in the transit service area through household income, age distributions, access to cars, and land use density. Since these demographic characteristics for the specific route areas were not available, this method could not be employed. 


\section{VC. EVALUATION OF COSTS}

After determining travel demands, the cost of the shuttle is presented in detail based on the vehicles that would be needed, the operating cost of service, and the available resources to recuperate the costs. Two choices are available to acquire the shuttle itself: 1) the vehicle may be provided by the contracted shuttle operator as part of the operating costs, so no vehicles need to be purchased, or 2) the vehicle may be purchased, which would give greater freedom of decision on vehicle specifications. The Capital Costs section describes the likely price range of some possible transit vehicles. The Operating Costs section covers the costs of service under common hourly rates. Available Resources discusses the revenue sources that can be expected from service as well as current grant opportunities.

\section{CAPITAL COSTS}

The type of vehicle used for operation varies greatly depending on the manufacturer, model, and condition of the shuttle. The American Public Transportation Association has determined the average cost of a suburban bus ( 1 door, greater than 27.5 feet) to be $\$ 324,377$ out of records from 115 operators. The average cost of a transit bus (2 doors, greater than 27.5 feet) is $\$ 469,928$, calculated from records of 3,388 operators (APTA, 2011). Average cost of a trolley replica bus is $\$ 567,226$, determined from records of 12 operators. Although demand response buses are not considered due to shorter service life, their costs 
are also noted. The average cost of a demand response suburban bus is $\$ 76,005$. The average cost of a demand response transit bus is $\$ 303,124$ (APTA, 2011).

Electric shuttles can be considered if there is a strong push for vehicle acquisition. Incorporation of electric shuttles aligns with goals to increase alternative energy in transportation. Ebus manufactures electric shuttles and charging equipment. The Ebus Electric Trolley would put more electric vehicles on the road and feature a trolley design that would be aesthetically attractive to passengers (an important factor among several survey respondents).In addition to the electric trolley, the specifications of all Ebus vehicles are listed in Table 3.

Table 3. ELECTRIC BUS VEHICLE COMPARISON

\begin{tabular}{|c|c|c|c|}
\hline & $\begin{array}{l}\text { Ebus Electric } \\
\text { Buses and Trolleys } \\
\text { - Fast Charge }\end{array}$ & $\begin{array}{l}\text { Ebus Fast } \\
\text { Charge Electric }\end{array}$ & $\begin{array}{l}\text { Ebus Hybrid } \\
\text { Electric Trolley }\end{array}$ \\
\hline Seats & 22 & 22 & 22 \\
\hline $\begin{array}{l}\text { Miles Between } \\
\text { Charge }\end{array}$ & 45 & 45 & \\
\hline Life Cycle & $\begin{array}{l}7 \text { years } \\
\text { (2000 cycles) }\end{array}$ & $\begin{array}{l}7 \text { years } \\
\text { (2000 cycles) }\end{array}$ & $\begin{array}{l}7 \text { years } \\
\text { (2000 cycles) }\end{array}$ \\
\hline Electric Charger & $\begin{array}{l}90 \mathrm{~kW} \text { fast charger } \\
(\$ 58,000)\end{array}$ & - & $\begin{array}{l}90 \mathrm{~kW} \text { fast charger } \\
(\$ 58,000)\end{array}$ \\
\hline Gas & - & - & $\begin{array}{l}60 \text { Gallon Diesel or } \\
\text { Propane Tank }\end{array}$ \\
\hline Price (Low) & $\$ 295,000$ & $\$ 305,000$ & $\$ 335,000$ \\
\hline Price (High) & $\$ 315,000$ & - & - \\
\hline
\end{tabular}


The useful life of a vehicle depends on type and maintenance. Diesel buses have a life of 12 years; minibuses have a life of 7 years; and vans have a life of 5 years. These numbers also assume corrective and preventative maintenance. In terms of long-term financing, longer useful lives should reduce the annualized costs of the vehicle.

\section{FUTURE VALUE AND PRESENT VALUE COMPARISON}

A projection of costs at different interest rates is used to estimate the cost of investment in new electric shuttles compared to an investment elsewhere if a grant for capital expenditures could not be obtained. An amount of money in the present can be translated to a future equivalent cost by applying a discount/interest rate, a factor that acknowledges the value of a dollar today is worth more than a dollar in the future. Many municipalities choose to use the interest rate at as the discount rate. In other words, an expenditure of $\$ 353,000$ would have an equivalent value of $\$ 464,524$ in 7 years if the interest rate is 4 percent compounded annually. In the 2009 Transportation Planning Handbook, the value at which states and local governments can issue bonds is between 4.5 and 5.5 percent (ITE, 2009). Applying rates ranging from 4 to 6 percent covers provides some leeway to account for reasonable fluctuations (Table 4). The intent of showing the equivalency costs of future values on present shuttle vehicle purchases is to provide a chance to consider where shuttle acquisition will be prioritized amidst numerous other projects that might be competing for the same funding source in the absence of a grant for capital purchases. 


$$
F=P(1+i)^{t}
$$

Where,

$P=$ the present value

$F=$ the future value after $t$ years (Net Present Value)

$i=$ the discount/interest rate

$t=$ the number of years into the future (7 years)

Table 4. PRESENT VALUE AND FUTURE VALUE EQUIVALENCY

\begin{tabular}{|c|l|l|l|l|l|l|}
\hline $\begin{array}{c}\text { Number } \\
\text { of Buses }\end{array}$ & $\begin{array}{l}\text { Cost of } \\
\text { Bus(es) }\end{array}$ & $\begin{array}{l}\text { Cost of } \\
\text { Charger }\end{array}$ & $\begin{array}{l}\text { Total Cost } \\
\text { (Present } \\
\text { Cost) }\end{array}$ & $\begin{array}{l}\text { Future } \\
\text { Value } \\
\text { Equivalent } \\
\text { (at 4\%) }\end{array}$ & $\begin{array}{l}\text { Future } \\
\text { Value } \\
\text { Equivalent } \\
\text { (at 5\%) }\end{array}$ & $\begin{array}{l}\text { Future } \\
\text { Value } \\
\text { Equivalent } \\
\text { (at 6\%) }\end{array}$ \\
\hline \multirow{2}{*}{1 bus } & $\$ 295,000$ & $\$ 58,000$ & $\$ 353,000$ & $\$ 464,524$ & $\$ 496,706$ & $\$ 530,781$ \\
\cline { 2 - 7 } & $\$ 315,000$ & $\$ 58,000$ & $\$ 373,000$ & $\$ 490,843$ & $\$ 524,848$ & $\$ 560,854$ \\
\hline \multirow{2}{*}{2 buses } & $\$ 295,000$ & $\$ 58,000$ & $\$ 648,000$ & $\$ 852,724$ & $\$ 911,801$ & $\$ 974,352$ \\
\cline { 2 - 8 } & $\$ 315,000$ & $\$ 58,000$ & $\$ 688,000$ & $\$ 905,361$ & $\$ 968,085$ & $\$ 1,034,498$ \\
\hline
\end{tabular}

\section{OPERATING COSTS}

Operating costs vary by type of operation; the cost of contracted services depends on the contracts of service. Maintenance and labor factor into the overall operating cost. Based on a review of shuttle services in the country, an expected range is between $\$ 50$ and $\$ 100$ per unit per hour. Table 4 shows the costs of some services. Many shuttles operate at around $\$ 60$ per unit per hour. The Transit Resource Center (2004) suggests that $\$ 50$ to $\$ 60$ per hour is a reasonable price for shuttle services. Shuttle services that are operated in-house by transit agencies tend to have higher operating costs due to cost of labor and overhead. 
Table 5. OPERATING COST PER HOUR

\begin{tabular}{|l|r|l|r|r|l|r|l|}
\hline & $\begin{array}{l}\text { Burlin- } \\
\text { game }\end{array}$ & $\begin{array}{l}\text { Emery } \\
\text {-Go- } \\
\text { Round }\end{array}$ & $\begin{array}{l}\text { ECCTA- } \\
\text { estimate }\end{array}$ & $\begin{array}{l}\text { Palo } \\
\text { Alto }\end{array}$ & $\begin{array}{l}\text { APTA- } \\
\text { (small } \\
\text { agencies) }\end{array}$ & iShuttle & $\begin{array}{l}\text { Menlo } \\
\text { Park }\end{array}$ \\
\hline Operating Cost per Hr & $\$ 65$ & $\$ 55$ & $\$ 65$ & $\$ 41$ & $\$ 75$ & $\$ 70$ & $\$ 45$ \\
\hline Average & \multicolumn{8}{|c|}{$\$ 59.36$} \\
\hline
\end{tabular}

The annual operating costs of a shuttle service depend on numerous factors in both route design and economic conditions; nonetheless, a few assumptions can be made to project the costs. Below is a list of assumptions applicable to the various route designs:

- One shuttle on the Railroad Avenue route can meet $1 / 2$ hour headways if it operates at speeds of at least $14 \mathrm{mph}$.

- One shuttle on the Century Plaza route can meet 1 hour headways if it operates at speeds of at least $10 \mathrm{mph}$ in Alternative 2 and $13 \mathrm{mph}$ in Alternative 3.

- For most service options, shuttles will operate for approximately 250 days per year, which are weekday operations for the year minus holidays and other occasions. 
Research of shuttle operators reveals that $\$ 60$ per hour is a fair price for service (Table 5). To account for a range of reasonable hourly rates, Table 6 (Railroad Avenue Route) and Table 7 (Two Route Structure) present the annual costs of each of these choices at different hourly rates under various route planning choices. These types of operation are also referenced in Chapter VI: Alternative Plans.

- "Weekday AM and PM Peak Only": Service operates for 3 hours in the AM peak from 6:30 am to $9: 30$ am and 3 hours in the PM peak from 3:30 pm to 6:30 pm.

- "Weekday AM and PM Peak, Plus Weekend All Day": Weekday service is 3 hours in the AM peak from 6:30 am to 9:30 am and 3 hours in the PM peak from 3:30 pm to $6: 30 \mathrm{pm}$. Weekend Service is 10 hours from 11 am to $9 \mathrm{pm}$. Service operates at the shortest possible headways using one vehicle per route for 10 hours on weekends.

- "Weekday All Day": Service operates at the shortest possible headways using one vehicle per route for 12 hours from $6: 30$ am to $6: 30 \mathrm{pm}$.

- "Weekday All Day with 30 Minute Peak Headways": Service operates at 30 minute headways during the AM peak (6:30 am to 9:30 am), midday peak (11:30 am to 1:30 pm), and PM peak (3:30 to 6:30). For off peak headways, service operates at the shortest possible headways using one vehicle per route. 
Table 6. OPERATING SUMMARY OF RAILROAD AVENUE ROUTE

\begin{tabular}{|c|c|c|c|c|c|c|c|c|c|c|c|c|}
\hline & \multicolumn{9}{|l|}{ Service Characteristics } & \multicolumn{3}{|c|}{ Annual Operating Costs (at \$_per hour) } \\
\hline & Description & Route & Headway & Time & $\begin{array}{l}\text { Hours } \\
\text { Per Day }\end{array}$ & $\begin{array}{l}\text { Days per } \\
\text { Week }\end{array}$ & $\begin{array}{l}\text { Weekday/ } \\
\text { Weekend Days }\end{array}$ & $\begin{array}{l}\text { Weeks } \\
\text { per Year }\end{array}$ & $\begin{array}{l}\text { Number of } \\
\text { Vehicles }\end{array}$ & $\$ 60$ & $\$ 70$ & $\$ 80$ \\
\hline \multirow[t]{2}{*}{$\begin{array}{l}\text { Weekday AM } \\
\text { and PM Peak } \\
\text { Only }\end{array}$} & \multirow{2}{*}{$\begin{array}{l}\text { Service operates for } 3 \\
\text { hours in the AM peak } \\
\text { and } 3 \text { hours in the PM } \\
\text { peak. }\end{array}$} & $\begin{array}{l}\text { Railroad } \\
\text { Avenue Route }\end{array}$ & $30 \mathrm{~min}$ & $\begin{array}{l}\text { 6:30am to } 9: 30 \mathrm{am} ; \\
\text { 3:30pm to } 6: 30 \mathrm{pm}\end{array}$ & 6 & 5 & Weekdays & 50 & 1 & $\$ 90,000$ & $\$ 105,000$ & $\$ 120,000$ \\
\hline & & Total & & & 6 & 5 & & 50 & 1 & $\$ 90,000$ & $\$ 105,000$ & $\$ 120,000$ \\
\hline \multirow{3}{*}{$\begin{array}{l}\text { Weekday AM } \\
\text { and PM Peak, } \\
\text { Plus Weekend } \\
\text { All Day }\end{array}$} & \multirow{3}{*}{$\begin{array}{l}\text { Service operates for } 3 \\
\text { hours in the AM peak } \\
\text { and } 3 \text { hours in the PM } \\
\text { peak for weekdays. } \\
\text { Service operates for } 10 \\
\text { hours on weekends. } \\
\end{array}$} & $\begin{array}{l}\text { Railroad } \\
\text { Avenue Route }\end{array}$ & $30 \mathrm{~min}$ & $\begin{array}{l}\text { 6:30am to } 9: 30 \mathrm{am} ; \\
\text { 3:30pm to } 6: 30 \mathrm{pm}\end{array}$ & 6 & 5 & Weekdays & 50 & 1 & $\$ 90,000$ & $\$ 105,000$ & $\$ 120,000$ \\
\hline & & $\begin{array}{l}\text { Railroad } \\
\text { Avenue Route }\end{array}$ & $30 \mathrm{~min}$ & 11:00am to 9:00pm & 10 & 2 & Weekend Days & 50 & 1 & $\$ 60,000$ & $\$ 70,000$ & $\$ 80,000$ \\
\hline & & Total & & & 16 & 7 & & 50 & 2 & $\$ 150,000$ & $\$ 175,000$ & $\$ 200,000$ \\
\hline \multirow[t]{2}{*}{$\begin{array}{l}\text { Weekday All } \\
\text { Day }\end{array}$} & \multirow[t]{2}{*}{$\begin{array}{l}\text { Service operates for } 12 \\
\text { hours. }\end{array}$} & \begin{tabular}{|l} 
Railroad \\
Avenue Route
\end{tabular} & $30 \mathrm{~min}$ & 6:30am to $6: 30 \mathrm{pm}$ & 12 & 5 & Weekdays & 50 & 1 & $\$ 180,000$ & $\$ 210,000$ & $\$ 240,000$ \\
\hline & & Total & & & 12 & 5 & & 50 & 1 & $\$ 180,000$ & $\$ 210,000$ & $\$ 240,000$ \\
\hline
\end{tabular}

Table 7. OPERATING SUMMARY OF TWO ROUTE STRUCTURE

\begin{tabular}{|c|c|c|c|c|c|c|c|c|c|c|c|c|}
\hline & \multicolumn{9}{|l|}{ Service Characteristics } & \multicolumn{3}{|c|}{ Annual Operating Costs (at \$_per hour) } \\
\hline & Description & Route & Headway & Time & $\begin{array}{l}\text { Hours } \\
\text { Per Day }\end{array}$ & $\begin{array}{l}\text { Days per } \\
\text { Week }\end{array}$ & $\begin{array}{l}\text { Weekday/ } \\
\text { Weekend Days }\end{array}$ & $\begin{array}{l}\text { Weeks } \\
\text { per Year }\end{array}$ & $\begin{array}{l}\text { Number of } \\
\text { Vehicles }\end{array}$ & $\$ 60$ & $\$ 70$ & $\$ 80$ \\
\hline \multirow{3}{*}{$\begin{array}{l}\text { Weekday } \\
\text { AM and PM } \\
\text { Peak Only }\end{array}$} & \multirow{3}{*}{$\begin{array}{l}\text { Service operates for } 3 \\
\text { hours in the AM peak } \\
\text { and } 3 \text { hours in the PM } \\
\text { peak. }\end{array}$} & \begin{tabular}{|l|} 
Railroad \\
Avenue Route
\end{tabular} & $30 \mathrm{~min}$ & $\begin{array}{l}\text { 6:30am to } 9: 30 \mathrm{am} ; \\
3: 30 \mathrm{pm} \text { to } 6: 30 \mathrm{pm}\end{array}$ & 6 & 5 & Weekdays & 50 & 1 & $\$ 90,000$ & $\$ 105,000$ & $\$ 120,000$ \\
\hline & & $\begin{array}{l}\text { Century Plaza } \\
\text { Route }\end{array}$ & $60 \mathrm{~min}$ & $\begin{array}{l}\text { 6:30am to } 9: 30 \mathrm{am} ; \\
\text { 3:30pm to } 6: 30 \mathrm{pm}\end{array}$ & 6 & 5 & Weekdays & 50 & 1 & $\$ 90,000$ & $\$ 105,000$ & $\$ 120,000$ \\
\hline & & Total & & & 12 & 5 & & 50 & 2 & $\$ 180,000$ & $\$ 210,000$ & $\$ 240,000$ \\
\hline \multirow{5}{*}{$\begin{array}{l}\text { Weekday } \\
\text { AM and PM } \\
\text { Peak, Plus } \\
\text { Weekend } \\
\text { All Day }\end{array}$} & \multirow{5}{*}{$\begin{array}{l}\text { Service operates for } 3 \\
\text { hours in the AM peak } \\
\text { and } 3 \text { hours in the PM } \\
\text { peak for weekdays. } \\
\text { Service operates at the } \\
\text { shortest possible } \\
\text { headways using one } \\
\text { vehicle per route for } 10 \\
\text { hours on weekends. }\end{array}$} & \begin{tabular}{|l|} 
Railroad \\
Avenue Route
\end{tabular} & $30 \mathrm{~min}$ & $\begin{array}{l}\text { 6:30am to } 9: 30 \mathrm{am} ; \\
3: 30 \mathrm{pm} \text { to } 6: 30 \mathrm{pm}\end{array}$ & 6 & 5 & Weekdays & 50 & 1 & $\$ 90,000$ & $\$ 105,000$ & $\$ 120,000$ \\
\hline & & $\begin{array}{l}\text { Century Plaza } \\
\text { Route }\end{array}$ & $60 \mathrm{~min}$ & $\begin{array}{l}\text { 6:30am to } 9: 30 \mathrm{am} ; \\
3: 30 \mathrm{pm} \text { to } 6: 30 \mathrm{pm}\end{array}$ & 6 & 5 & Weekdays & 50 & 1 & $\$ 90,000$ & $\$ 105,000$ & $\$ 120,000$ \\
\hline & & \begin{tabular}{|l} 
Railroad \\
Avenue Route
\end{tabular} & $30 \mathrm{~min}$ & 11:00am to $9: 00 \mathrm{pm}$ & 10 & 2 & Weekend Days & 50 & 1 & $\$ 60,000$ & $\$ 70,000$ & $\$ 80,000$ \\
\hline & & $\begin{array}{l}\text { Century Plaza } \\
\text { Route }\end{array}$ & $60 \mathrm{~min}$ & 11:00am to 9:00pm & 10 & 2 & Weekend Days & 50 & 1 & $\$ 60,000$ & $\$ 70,000$ & $\$ 80,000$ \\
\hline & & Total & & & 32 & 7 & & 50 & 4 & $\$ 300,000$ & $\$ 350,000$ & $\$ 400,000$ \\
\hline \multirow[t]{3}{*}{$\begin{array}{l}\text { Weekday } \\
\text { All Day }\end{array}$} & \multirow{3}{*}{$\begin{array}{l}\text { Service operates at the } \\
\text { shortest possible } \\
\text { headways using one } \\
\text { vehicle per route for } 12 \\
\text { hours. }\end{array}$} & \begin{tabular}{|l|} 
Railroad \\
Avenue Route
\end{tabular} & $30 \mathrm{~min}$ & 6:30am to $6: 30 \mathrm{pm}$ & 12 & 5 & Weekdays & 50 & 1 & $\$ 180,000$ & $\$ 210,000$ & $\$ 240,000$ \\
\hline & & $\begin{array}{l}\text { Century Plaza } \\
\text { Route }\end{array}$ & $60 \mathrm{~min}$ & 6:30am to $6: 30 \mathrm{pm}$ & 12 & 5 & Weekdays & 50 & 1 & $\$ 180,000$ & $\$ 210,000$ & $\$ 240,000$ \\
\hline & & Total & & & 24 & 5 & & 50 & 2 & $\$ 360,000$ & $\$ 420,000$ & $\$ 480,000$ \\
\hline \multirow{4}{*}{$\begin{array}{l}\text { Weekday } \\
\text { All Day with } \\
30 \text { Minute } \\
\text { Peak } \\
\text { Headways }\end{array}$} & \multirow{4}{*}{$\begin{array}{l}\text { Service operates at } 30 \\
\text { minute headways } \\
\text { during the AM, midday, } \\
\text { and PM peak. For } \\
\text { offpeak headways, } \\
\text { service operates at the } \\
\text { shortest possible } \\
\text { headways using one }\end{array}$} & \begin{tabular}{|l|} 
Railroad \\
Avenue Route
\end{tabular} & $30 \mathrm{~min}$ & $6: 30 \mathrm{am}$ to $6: 30 \mathrm{pm}$ & 12 & 5 & Weekdays & 50 & 1 & $\$ 180,000$ & $\$ 210,000$ & $\$ 240,000$ \\
\hline & & $\begin{array}{l}\text { Century Plaza } \\
\text { Route }\end{array}$ & $30 \mathrm{~min}$ & $\begin{array}{l}\text { 6:30am to 9:30am; } \\
\text { 11:30 to 1:30; } \\
\text { 3:30pm to } 6: 30 \mathrm{pm}\end{array}$ & 8 & 5 & Weekdays & 50 & 2 & $\$ 240,000$ & $\$ 280,000$ & $\$ 320,000$ \\
\hline & & & $60 \mathrm{~min}$ & $\begin{array}{l}\text { 9:30am to } 11: 30 \\
1: 30 \text { to } 3: 30 \mathrm{pm}\end{array}$ & 4 & 5 & Weekdays & 50 & 1 & $\$ 60,000$ & $\$ 70,000$ & $\$ 80,000$ \\
\hline & & Total & & & 24 & 5 & & 50 & 4 & $\$ 480,000$ & $\$ 560,000$ & $\$ 640,000$ \\
\hline
\end{tabular}

There are opportunity costs in maintaining a shuttle. The money set aside for operations could be invested elsewhere, especially if a dedicated grant or external funding source for the shuttle could not be obtained. To illustrate the costs tied up in the investment, an examination of the present value of contributions over 
an extended period of time shows both the absolute and relative costs of the investment at the end of seven years. Drawing from the annual operating costs presented in Table 6, both the absolute costs and the relative present value costs at the end of seven years is shown in Table 8 for the Railroad Avenue Route alternative. Operating costs for Table 7 are shown as present value equivalents in Table 9. All costs shown here feature the total operating costs (excluding capital purchases for shuttle vehicles)). The table shows how the costs of the investment stack up after seven years, with the absolute dollar value (the amount that would be recorded in invoices) and the present value (the relative amounts when discount rates are applied). A set of possible discount rates at 4 percent, 5 percent, and 6 percent are used to calculate the present value of a uniform set of annual payments. Discount rates can be considered the interest rates applied for an amount of money. More accurately, discount rates refer to the idea of the time value of money, where a dollar today is worth more to a person than a dollar in the future. It also reflects the capital investment potential of money that would be lost because funds are tied up in an investment. No actual money is lost, but the potential to invest the money into something else has been relinquished. The "power of capital" in Tables 8 and 9 refer to the relinquishment of capital potential at varying discount rates. Simply put, the lump sum of the amount paid (Absolute Value) is equal to a relative amount paid in lump sum today (Present Value at Discount Rates) and the difference is the investment potential relinquished (Power of Capital Held Up in Investment) due to the discount rate. 


$$
P V=A *\left(\frac{(1+i)^{n}-1}{i(1+i)^{n}}\right)
$$

Where,

$P V=$ Present value as equal annual payments

$A=$ Annual payment

$i=$ discount rate

$n=$ number of years

Table 8. PRESENT VALUE COST FOR SINGLE ROUTE STRUCTURE

\begin{tabular}{|c|c|c|c|c|c|c|c|c|c|}
\hline & & \multirow{2}{*}{$\begin{array}{l}\text { Annual } \\
\text { Cost }\end{array}$} & \multirow{2}{*}{$\begin{array}{c}\text { Absolute } \\
\text { Value for } \\
7 \text { Year } \\
\text { Sum }\end{array}$} & \multicolumn{3}{|c|}{$\begin{array}{c}\text { Present Value at Discount Rates } \\
\text { (at the End of } 7 \text { Years) }\end{array}$} & \multicolumn{3}{|c|}{$\begin{array}{l}\text { Power of Capital Held Up in } \\
\text { Investment* }\end{array}$} \\
\hline & & & & 0.04 & 0.05 & 0.06 & 0.04 & 0.05 & 0.06 \\
\hline \multirow{3}{*}{$\begin{array}{l}\$ 60 \text { per } \\
\text { hour }\end{array}$} & $\begin{array}{l}\text { Weekday AM and PM } \\
\text { Peak Only }\end{array}$ & 90,000 & 630,000 & 540,185 & 520,774 & 502,414 & 89,815 & 109,226 & 127,586 \\
\hline & $\begin{array}{l}\text { Weekday AM and PM } \\
\text { Peak, Plus Weekend All } \\
\text { Day }\end{array}$ & 150,000 & $1,050,000$ & 900,308 & 867,956 & 837,357 & 149,692 & 182,044 & 212,643 \\
\hline & Weekday All Day & 180,000 & $1,260,000$ & $1,080,370$ & $1,041,547$ & $1,004,829$ & 179,630 & 218,453 & 255,171 \\
\hline \multirow{3}{*}{$\begin{array}{l}\$ 70 \text { per } \\
\text { hour }\end{array}$} & $\begin{array}{l}\text { Weekday AM and PM } \\
\text { Peak Only }\end{array}$ & 105,000 & 735,000 & 630,216 & 607,569 & 586,150 & 104,784 & 127,431 & 148,850 \\
\hline & $\begin{array}{l}\text { Weekday AM and PM } \\
\text { Peak, Plus Weekend All } \\
\text { Day }\end{array}$ & 175,000 & $1,225,000$ & $1,050,360$ & $1,012,615$ & 976,917 & 174,640 & 212,385 & 248,083 \\
\hline & Weekday All Day & 210,000 & $1,470,000$ & $1,260,431$ & $1,215,138$ & $1,172,300$ & 209,569 & 254,862 & 297,700 \\
\hline \multirow{3}{*}{$\begin{array}{l}\$ 80 \text { per } \\
\text { hour }\end{array}$} & $\begin{array}{l}\text { Weekday AM and PM } \\
\text { Peak Only }\end{array}$ & 120,000 & 840,000 & 720,247 & 694,365 & 669,886 & 119,753 & 145,635 & 170,114 \\
\hline & $\begin{array}{l}\text { Weekday AM and PM } \\
\text { Peak, Plus Weekend All } \\
\text { Day }\end{array}$ & 200,000 & $1,400,000$ & $1,200,411$ & $1,157,275$ & $1,116,476$ & 199,589 & 242,725 & 283,524 \\
\hline & Weekday All Day & 240,000 & $1,680,000$ & $1,440,493$ & $1,388,730$ & $1,339,772$ & 239,507 & 291,270 & 340,228 \\
\hline
\end{tabular}

${ }^{*}$ Difference between Absolute Value for 7 Year Sum and Present Value at Discount Rate 
Table 9. PRESENT VALUE COST FOR TWO ROUTE STRUCTURE

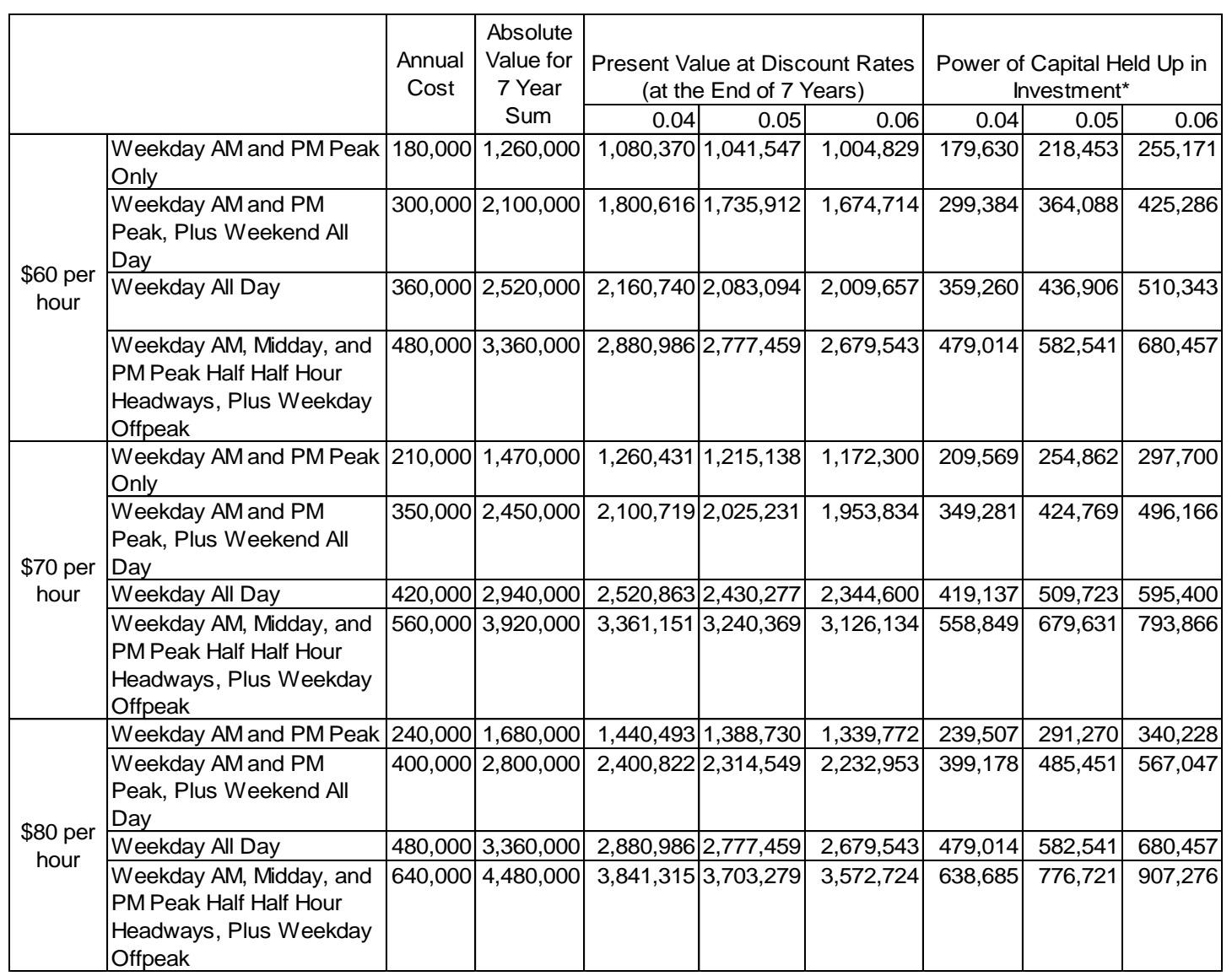

*Difference between Absolute Value for 7 Year Sum and Present Value at Discount Rate

Alternatively, the total cost of operations can also be examined as the sum of annual operating cost and the amortization of the capital costs over 7 years. This fully-amortized cost analysis projects financial requirements if operating cost and vehicle acquisition are not funded through grants or other external revenue sources. Annual operating cost is calculated in Table 6 for a single route and Table 7 for two routes. The amortized annual cost is calculated using capital cost from Table 4 and various interest rates. The amortization equation is shown below, 
where $A$ is the amortized annual capital cost computed from dividing the present value of the capital cost, $P V$, by a conversion factor involving interest rate, $i$, over a period of $n$ years (7 years was chosen for this analysis). Total cost incorporating annual operating cost and amortized capital cost is shown in Table 10 for a single route structure and in Table 11 for a two-route structure.

$$
A=\frac{P V}{\left(\frac{(1+i)^{n}-1}{i(1+i)^{n}}\right)}
$$

Where,

$A=$ Amortized annual capital cost

$P V=$ Present value of capital cost over $n$ years

$i=$ interest rate

$n=$ number of years ( 7 for this analysis)

Table 10. FULLY-AMORTIZED ANNUAL COST FOR SINGLE ROUTE STRUCTURE

\begin{tabular}{|c|c|c|c|c|c|c|c|c|c|}
\hline & & \multirow{2}{*}{$\begin{array}{l}\text { Annual } \\
\text { Operating } \\
\text { Cost }\end{array}$} & \multirow{2}{*}{$\begin{array}{c}\text { Capital } \\
\text { Cost } \\
\text { (Table 4) }\end{array}$} & \multicolumn{3}{|c|}{$\begin{array}{c}\text { Amortized Annual Capital Cost at } \\
\text { Varying Interest Rates Over } 7 \text { Years }\end{array}$} & \multicolumn{3}{|c|}{$\begin{array}{c}\text { Total Annual Cost } \\
\text { (Operating and Amortized Capital Costs) }\end{array}$} \\
\hline & & & & 0.04 & 0.05 & 0.06 & 0.04 & 0.05 & 0.06 \\
\hline \multirow{3}{*}{$\begin{array}{l}\$ 60 \text { per } \\
\text { hour }\end{array}$} & $\begin{array}{l}\text { Weekday AM and PM } \\
\text { Peak Only }\end{array}$ & 90,000 & 353,000 & 58,813 & 61,005 & 63,235 & 148,813 & 151,005 & 153,235 \\
\hline & $\begin{array}{l}\text { Weekday AM and PM } \\
\text { Peak, Plus Weekend } \\
\text { All Day }\end{array}$ & 150,000 & 353,000 & 58,813 & 61,005 & 63,235 & 208,813 & 211,005 & 213,235 \\
\hline & Weekday All Day & 180,000 & 353,000 & 58,813 & 61,005 & 63,235 & 238,813 & 241,005 & 243,235 \\
\hline \multirow{3}{*}{$\begin{array}{l}\$ 70 \text { per } \\
\text { hour }\end{array}$} & $\begin{array}{l}\text { Weekday AM and PM } \\
\text { Peak Only }\end{array}$ & 105,000 & 353,000 & 58,813 & 61,005 & 63,235 & 163,813 & 166,005 & 168,235 \\
\hline & $\begin{array}{l}\text { Weekday AM and PM } \\
\text { Peak, Plus Weekend } \\
\text { All Day }\end{array}$ & 175,000 & 353,000 & 58,813 & 61,005 & 63,235 & 233,813 & 236,005 & 238,235 \\
\hline & Weekday All Day & 210,000 & 353,000 & 58,813 & 61,005 & 63,235 & 268,813 & 271,005 & 273,235 \\
\hline \multirow{3}{*}{$\begin{array}{l}\$ 80 \text { per } \\
\text { hour }\end{array}$} & $\begin{array}{l}\text { Weekday AM and PM } \\
\text { Peak Only }\end{array}$ & 120,000 & 353,000 & 58,813 & 61,005 & 63,235 & 178,813 & 181,005 & 183,235 \\
\hline & $\begin{array}{l}\text { Weekday AM and PM } \\
\text { Peak, Plus Weekend } \\
\text { All Day }\end{array}$ & 200,000 & 353,000 & 58,813 & 61,005 & 63,235 & 258,813 & 261,005 & 263,235 \\
\hline & Weekday All Day & 240,000 & 353,000 & 58,813 & 61,005 & 63,235 & 298,813 & 301,005 & 303,235 \\
\hline
\end{tabular}


Table 11. FULLY-AMORTIZED ANNUAL COST FOR TWO ROUTE STRUCTURE

\begin{tabular}{|c|c|c|c|c|c|c|c|c|c|}
\hline & & \multirow{2}{*}{$\begin{array}{l}\text { Annual } \\
\text { Operating } \\
\text { Cost }\end{array}$} & \multirow{2}{*}{$\begin{array}{l}\text { Capital Cost } \\
\text { (Table 4) }\end{array}$} & \multicolumn{3}{|c|}{$\begin{array}{l}\text { Amortized Annual Capital Cost at } \\
\text { Varying Interest Rates Over } 7 \text { Years }\end{array}$} & \multicolumn{3}{|c|}{$\begin{array}{c}\text { Total Annual Cost } \\
\text { (Operating and Amortized Capital Costs) }\end{array}$} \\
\hline & & & & 0.04 & 0.05 & 0.06 & 0.04 & 0.05 & 0.06 \\
\hline \multirow{4}{*}{$\begin{array}{l}\$ 60 \text { per } \\
\text { hour }\end{array}$} & $\begin{array}{l}\text { Weekday AM and PM } \\
\text { Peak Only }\end{array}$ & 180,000 & 648,000 & 107,963 & 111,987 & 116,079 & 287,963 & 291,987 & 296,079 \\
\hline & $\begin{array}{l}\text { Weekday AM and PM } \\
\text { Peak, Plus Weekend } \\
\text { All Day }\end{array}$ & 300,000 & 648,000 & 107,963 & 111,987 & 116,079 & 407,963 & 411,987 & 416,079 \\
\hline & Weekday All Day & 360,000 & 648,000 & 107,963 & 111,987 & 116,079 & 467,963 & 471,987 & 476,079 \\
\hline & $\begin{array}{l}\text { Weekday AM, Midday, } \\
\text { and PM Peak Half Half } \\
\text { Hour Headways, Plus } \\
\text { Weekday Offpeak }\end{array}$ & 480,000 & 648,000 & 107,963 & 111,987 & 116,079 & 587,963 & 591,987 & 596,079 \\
\hline \multirow{4}{*}{$\begin{array}{l}\$ 70 \text { per } \\
\text { hour }\end{array}$} & $\begin{array}{l}\text { Weekday AM and PM } \\
\text { Peak Only }\end{array}$ & 210,000 & 648,000 & 107,963 & 111,987 & 116,079 & 317,963 & 321,987 & 326,079 \\
\hline & $\begin{array}{l}\text { Weekday AM and PM } \\
\text { Peak, Plus Weekend } \\
\text { All Day }\end{array}$ & 350,000 & 648,000 & 107,963 & 111,987 & 116,079 & 457,963 & 461,987 & 466,079 \\
\hline & Weekday All Day & 420,000 & 648,000 & 107,963 & 111,987 & 116,079 & 527,963 & 531,987 & 536,079 \\
\hline & $\begin{array}{l}\text { Weekday AM, Midday, } \\
\text { and PM Peak Half Half } \\
\text { Hour Headways, Plus } \\
\text { Weekday Offpeak }\end{array}$ & 560,000 & 648,000 & 107,963 & 111,987 & 116,079 & 667,963 & 671,987 & 676,079 \\
\hline \multirow{4}{*}{$\begin{array}{c}\$ 80 \text { per } \\
\text { hour }\end{array}$} & Weekday AM and PM & 240,000 & 648,000 & 107,963 & 111,987 & 116,079 & 347,963 & 351,987 & 356,079 \\
\hline & $\begin{array}{l}\text { Weekday AM and PM } \\
\text { Peak, Plus Weekend } \\
\text { All Day }\end{array}$ & 400,000 & 648,000 & 107,963 & 1111,987 & 116,079 & 507,963 & 511,987 & 516,079 \\
\hline & Weekday All Day & 480,000 & 648,000 & 107,963 & 111,987 & 116,079 & 587,963 & 591,987 & 596,079 \\
\hline & $\begin{array}{l}\text { Weekday AM, Midday, } \\
\text { and PM Peak Half Half } \\
\text { Hour Headways, Plus } \\
\text { Weekday Offpeak }\end{array}$ & 640,000 & 648,000 & 107,963 & 111,987 & 116,079 & 747,963 & 751,987 & 756,079 \\
\hline
\end{tabular}


AVAILABLE RESOURCES

Variations in fare levels can provide some financial support for shuttle operation. Fare revenue must first be determined from the proportion of likely users. Ballpark figures for population at key locations are gathered from the comments and rough estimates of the Pittsburg planning staff. Number of trips per day determines revenue recovery at different fare levels.

\section{FARE}

Fare revenue could provide a small source of funding to support services. Revenue recovery alone cannot cover a significant portion of operating cost. A passenger fare of $\$ 1.00$ per ride seems acceptable to respondents on the survey. But even at $\$ 60$ per hour, the service would need to consistently maintain 60 passengers over the operating period to recover costs. It is possible that passengers would be willing to pay more than $\$ 1.00$ per ride because respondents have stated that Tri Delta fares are $\$ 2.00$. There are three major options in terms of fare requirements: require no fare, institute an acceptable fair to passengers, or implement a fare level to recover the majority (if not complete) cost of operations. Because fares at low rates may not recover a substantial amount of the cost, offering the service free of fares and finding a funding source elsewhere will provide a service that benefits residents and encourages transit travel. Instituting an acceptable fair would help recover some cost of operation but attract fewer riders. Implementing fare levels so that they may recover the greatest possible cost may dissuade transit usage among potential riders. 
Whichever option is selected, consistency in fare levels is very important. Mode choice is sensitive to price changes in fuel costs for automobiles and fare levels for transit. Transit trips increase as fuel prices rise; transit trips decrease as cost to the passenger increases (Maghelal, 2011). Although transit is generally an inelastic commodity, there can be variations in demand levels. ITE (2009) states that typical demand elasticity as they relate to price is -0.4 for off-peak periods and -0.2 for peak periods. As an example, a -0.4 elasticity means that a 1 percent increase in fares will cause a 0.4 percent decrease in ridership in the off-peak period. Chiang et al. (2011) cite a generally accepted fare elasticity level of -0.3 , a value between the two ranges from ITE. Chen et al. (2011) believe that fare elasticity can have short-term and long-term impacts. For instance, a one percent increase in fare can have a 0.4 percent decrease in ridership in the short-term but a 0.8 percent decrease in the long term.

\section{LOCAL CONTRIBUTION}

Surveys and interviews with local business owners reveal a generally positive response to the idea of a shuttle system, but business owners showed a tepid response in financially helping the system. A brief discussion with a member of Pittsburg's Chamber of Commerce also reinforced the idea that while a shuttle service along Railroad Avenue could improve travel to the Old Town area and various commercial locations, business owners are unlikely to make any substantial financial contribution to the shuttle in the current economic environment. At a monthly fee of $\$ 25$ per month, it is assumed that 20 businesses 
would be willing to contribute to shuttle service near their businesses. The potential to increase the number of participating businesses and the amount of monthly contributions would have to come from an approach that persuades businesses to buy in to the shuttle concept. Among a few successful case study examples like Emeryville's Emery-Go-Round and the Oakland Free-B, contributions from local businesses and organizations provide sizeable portions of operating funds. An assessment district or a commercial fee agreement in an area can generate a constant source of support and provide a more equitable distribution of costs to benefit all businesses. Although businesses may be willing to make some contributions to the shuttle program, a large financial support system should not be expected from businesses at this time.

In many cases, local sales tax measures provide funding sources for a variety of transportation projects. Measure $\mathrm{J}$ (Local Sales Tax) is the $1 / 2$ cent sales tax in Contra Costa County. The expenditure plan has allocated $\$ 20$ million to commute alternative projects. In a politically-opportune environment, citizens may support a bond measure to improve transportation projects. Dixit et al. (2010) discovered that bond measures were more likely to succeed than tax measures in a study of one hundred eleven referenda. Tax-based proposals generally outnumber bond proposals, but the pass rate for tax measures (48 percent) is much lower than the pass rate for bond measures (77 percent) (Dixit et al., 2010). Nonetheless, it would be difficult to leverage any kind of tax on service in the current environment. 
GRANTS

The Bay Area Air Quality Management District (BAAQMD) distributes awards for emission reduction transportation progrms through the Transportation Fund for Clean Air (TCFA). Many shuttle services in the Bay Area rely on BAAQMD for a large portion of operating revenue. The TFCA program is divided into two options: the Regional Fund and the County Program Manager Fund.

The County Programming Manager Fund, supported by a $\$ 4$ vehicle registration charge, considers shuttle projects that provide service to rail stations. Shuttle projects are eligible for up to two years of funding - subsequent requests require reapplication. Projects are reviewed on three key points(BAAQMD, 2012a):

- Project provides service to relatively large number of riders/participants that otherwise would have driven alone.

- Shuttle provides "first and last mile" connection to employers and transit.

- Shuttle travels relatively short distances between start and end points and has minimal amount of non-service miles.

According to guidance criteria from the Grant Opportunity Announcement for Shuttle/Feeder Bus and Regional Ridesharing Projects, "Pilot shuttle/feeder bus service projects are required to meet a cost-effectiveness of $\$ 125,000 /$ ton during the first two years of operation. A pilot project is a defined route that is at least $70 \%$ unique and has not previously been funded through TFCA. Applicants must provide data supporting the demand for the service, letters of support from potential users and providers, and plans for financing the service in the future" (BAAQMD, 2012a). The program evaluates cost effectiveness as "the ratio of 
TFCA funds awarded divided by the sum total tons of reactive organic gases (ROG), oxides of nitrogen (NOx), and weighted particulate matter 10 microns in diameter and smaller (PM10) reduced (\$/ton)" (BAAQMD, 2012a).

The Regional Fund has similar criteria to the County Programming Manager Fund. The project must meet a $\$ 90,000$ per ton cost effectiveness ratio, defined as "the ratio of TFCA funds awarded divided by the sum total tons of reactive organic gases (ROG), oxides of nitrogen (NOx), and weighted particulate matter 10 microns in diameter and smaller (PM10) reduced (\$/ton)" (BAAQMD, 2012b).

- TFCA cost-effectiveness of $\$ 90,000 /$ ton.

- Consistent with existing plans and programs

- Be an eligible recipient (public agencies are eligible)

- Viable matching funds. A matching fund of at least 10 percent must be made from a non-Air District source

- Minimum grant is $\$ 10,000$ per project. Maximum grant is $\$ 1.5$ million per year

- Projects must commence in 2013

- Projects requesting up to $\$ 100,000$ annually are eligible for 2 years of funding. Projects that request more than $\$ 100,000$ are only eligible for one year of funding.

According to the FY 2013 Regional Fund Guidance, "Pilot projects are defined as new routes that are at least $70 \%$ unique and have not been in operation in the past five years. In addition to meeting the requirements listed in Policy 27 for Shuttle/Feeder Bus Service, pilot shuttle/feeder project applicants must also provide data supporting the demand for the service, including letters of support from potential users and providers, and plans for financing the service in the future. Pilot projects must meet and maintain a minimum cost-effectiveness of 
$\$ 125,000 /$ ton during the first year of operation and a minimum cost-effectiveness of $\$ 90,000$ by the end of the second year of operation. Projects may only receive a maximum of two years of funding under the Pilot designation" (BAAQMD, 2012b).

"The final destination must be a distinct commercial, employment or residential area. The project's route must operate to or from a mass transit hub and must coordinate with the transit schedules of the connecting mass transit services. Project routes cannot replace or duplicate an existing local transit service link. These services are intended to support and complement use of existing major mass transit services" (BAAQMD, 2013b).

The US Department of Transportation provides competitive grants for new and replacement transit vehicles. Previous award recipients include transit agencies, metropolitan planning organizations, and local governments in partnership with transit agencies. Information is updated at http://fta.dot.gov/grants/. Grants 5309 and 5318 provide funding for new and replacement vehicles. Grant 5308 supports clean fuel technologies for transit.

Although there are several opportunities to acquire grants and funding sources, extensive work will be required. A long-term funding strategy has yet to be acquired. Like the Railroad Avenue Specific Plan, which has also identified a shuttle in its proposal, funding will be anticipated from several general sources, such as sales tax, business and property-owner assessment districts, downtown business owner assessment district, and grants. 


\section{ALTERNATIVE FINANCING MECHANISMS}

Large group buy-ins or business contributions may significantly offset the cost of service. Full fare coverage, deep discount group passes, and full business sponsorship are options inspired by Dr. Cornelius Nuworsoo, author of the paper "Deep Discount Group Pass Programs as Instruments for Increasing Transit Revenue and Ridership" (Nuworsoo, 2004). The three different mechanisms in group-focused cost recovery demonstrate how the shuttle provider and the potential rider can benefit from large-scale support of shuttle operation. For the shuttle provider, operating costs can be covered through large groups of contributors. For the potential rider, a large pool of contributors decreases the individual cost of a shuttle trip. The cost recovery can be examined in terms of operating cost recovery only or fully-amortized total cost recovery that includes both operating cost and amortized annual capital cost (Table 10). Both scenarios are presented in the three mechanisms.

\section{FULL FARE COVERAGE}

Full fare coverage assumes that the cost of shuttle operation is offset by passenger fares alone. Under this scenario, the fare level will be set high enough to break even with costs. The break-even cost is the annual operating cost of the shuttle divided by the number of passengers. The example in Table 12 shows break-even fare calculation in the Railroad Avenue route option, assuming a best case scenario consisting of the lowest operating cost $(\$ 90,000)$ and the highest ridership $(30,322)$. In this case, the break-even fare would not be feasible because 
the required $\$ 2.97$ is much higher than current fare of $\$ 2.00$. The break-even price of a fully-amortized total cost recovery is $\$ 4.98$, which also makes it infeasible. The calculation can be repeated to find the ridership required for acceptable break-even fares or to find the annual operating costs that would create acceptable break-even fares.

$$
\text { Break even Fare }=\frac{\text { Annual Operating Cost }}{\text { Annual Passengers }}
$$

Table 12. FULL FARE COVERAGE EXAMPLE

\begin{tabular}{|c|c|c|}
\hline & $\begin{array}{l}\text { Annual } \\
\text { Operating } \\
\text { Costs Only }\end{array}$ & $\begin{array}{l}\text { Total Annual Cost } \\
\text { (Operating Cost and } \\
\text { Amortized Capital } \\
\text { Cost at 5\% Interest) }\end{array}$ \\
\hline Annual Operating Cost & $\$ 90,000$ & $\$ 151,005$ \\
\hline $\begin{array}{l}\text { Annual Passengers } \\
\text { (Passengers per hour } \\
\text { times operating hours per } \\
\text { year) }\end{array}$ & 30,322 & 30,322 \\
\hline $\begin{array}{l}\text { Break even Cost (Annual } \\
\text { Operating Costs divided } \\
\text { by Annual Passengers) }\end{array}$ & $\$ 2.97$ & $\$ 4.98$ \\
\hline Tri Delta Fare & $\$ 2.00$ & $\$ 2.00$ \\
\hline Verdict & $\begin{array}{l}\text { Not feasible: } \\
\text { large } \\
\text { difference } \\
\text { between } \\
\text { fares }\end{array}$ & $\begin{array}{l}\text { Not feasible: large } \\
\text { difference between } \\
\text { fares }\end{array}$ \\
\hline
\end{tabular}




\section{DEEP DISCOUNT GROUP PASS}

The principle of deep discount group passes is based on the idea that groups of residents or employees will participate in a transit pass program capable of offsetting operating cost. As more people join the pass program, the price of each person's transit pass decreases. The price of the transit pass is calculated as the annual cost of the shuttle divided by the number of participants in the pass program. Table 13 provides an example showing the price of a transit pass assuming best case scenarios. At an operating cost of $\$ 90,000$ (the lowest cost for a single route shuttle option) and 2120 employees (the highest participation among retail employees in Pittsburg), the price of an annual unlimited ride pass is $\$ 42.25$, or $\$ 3.54$ per month. The price of a pass is somewhat higher when this option is used to offset the fully-amortized total annual cost. The calculation can be repeated to find the price of an annual pass assuming various participation levels.

$$
\text { Price of Transit Pass }=\frac{\text { Annual Operating Cost }}{\text { Participants in the Deep Discount Group }}
$$

Table 13. DEEP DISCOUNT GROUP PASS EXAMPLE

\begin{tabular}{|l|r|r|}
\hline & $\begin{array}{l}\text { Annual } \\
\text { Operating } \\
\text { Costs Only }\end{array}$ & $\begin{array}{l}\text { Total Annual Cost } \\
\text { (Operating Cost and } \\
\text { Amortized Capital } \\
\text { Cost at 5\% Interest) }\end{array}$ \\
\hline Annual Operating Cost & $\$ 90,000$ & $\$ 151,005$ \\
\hline Employees & 2120 & 2120 \\
\hline $\begin{array}{l}\text { Annual Cost of Deep } \\
\text { Discount Group Passes } \\
\text { (DDTP) per Employee }\end{array}$ & $\$ 42.45$ & $\$ 71.23$ \\
\hline $\begin{array}{l}\text { Monthly Cost of DDGP } \\
\text { per Employee }\end{array}$ & $\$ 3.54$ & $\$ 5.94$ \\
\hline
\end{tabular}


FULL BUSINESS SPONSORSHIP

Full business sponsorship consists of business contributions that offset the operating costs. Like the deep discount group pass option, the amount of contributions per business decreases as the number of participating business increases. Table 14 shows an example of the business contribution calculation. With a cost of $\$ 90,000$ and 200 sponsors, each business would only need to contribute $\$ 37.50$ dollars per month. If fully-amortized total annual cost should be recovered, the contribution increases to $\$ 62.92$ per month. The calculation can be repeated to find the contribution assuming different numbers of sponsors.

$$
\text { Business Contribution }=\frac{\text { Annual Operating Cost }}{\text { Sponsoring Businesses }}
$$

Table 14. FULL BUSINESS SPONSORSHIP EXAMPLE

\begin{tabular}{|l|r|r|}
\hline & $\begin{array}{l}\text { Annual } \\
\text { Operating } \\
\text { Costs Only }\end{array}$ & $\begin{array}{l}\text { Total Annual Cost } \\
\text { (Operating Cost and } \\
\text { Amortized Capital } \\
\text { Cost at 5\% Interest) }\end{array}$ \\
\hline Annual Operating Cost & $\$ 90,000$ & $\$ 151,005$ \\
\hline $\begin{array}{l}\text { Businesses Sponsoring } \\
\text { Shuttle }\end{array}$ & 200 & 200 \\
\hline $\begin{array}{l}\text { Annual Sponsorship per } \\
\text { Business }\end{array}$ & $\$ 450$ & $\$ 755$ \\
\hline $\begin{array}{l}\text { Monthly Sponsorship per } \\
\text { Business }\end{array}$ & $\$ 37.50$ & $\$ 62.92$ \\
\hline
\end{tabular}




\section{CHAPTER VI. ALTERNATIVE PLANS}

Several possible shuttle route alignments are presented for consideration. Although the scope of shuttle planning is not constrained to the three alternative plans presented, these plans provide different types of route planning options that satisfy different priorities, from the plan that most effectively limits costs to the plan that serves the most potential passengers. Alternative 1: Railroad Avenue shows the shuttle alignment at the most basic level along Railroad Avenue that minimizes costs. Alternative 2: Century Plaza Route $(C)$ is an expansion of the plan presented in Alternative 1 that includes an east-west commercial connection to increase the scope of service. Alternative 3: Century Plaza Route ( $L$ ) also expands upon the plan presented in Alternative 1 but proposes a different east-west alignment that would serve a greater proportion of the population. 


\section{VIA. GLOSSARY OF TERMS}

This section contains key concepts that would be referenced in the alternative plans. Standards presented here provide a general range of values that reflect common shuttle operating principles.

Dwell Time: This analysis applies a dwell time of 15 seconds per stop. Dwell time is the time in which a transit vehicle is stopped to serve passengers, including boarding, alighting, and opening and closing doors. Average dwell time can be between 12 to 15 seconds but vary depending on boarding conditions. A study conducted on TriMet buses showed that average dwell time was approximately 12 seconds, with a standard deviation of about 13 seconds (Deuker et al., 2004). Buses that operate in an urban arterial have an average dwell time of 15 seconds (Jacques and Levinson, 1997). Where chair lifts are operated, Deuker et al. (2004) have found a middle estimate of 62 seconds was a reasonable value applied to TriMet Transit operations. Dwell times can have some variability due to demographics (longer wait periods for elderly passengers), fare payment methods (payment with whole dollars or with change), and the number of passengers. Deuker et al. (2004) cite a 1983 Levinson study, "Analyzing Transit Travel Time" in Transportation Research Record 916, where dwell time was calculated as 5 seconds plus 2.75 seconds for each boarding or alighting. 
HBShop Trip: Home-based Shopping Trips. A trip from home to a commercial area for the primary purpose of shopping. The Contra Costa Transportation Authority has calculated the proportion of HBShop trips made by transit in Contra Costa County at 4 percent (CCTA, 2003).

Headway: Time between two vehicles on the same route (NTD, 2012)

Operating Hours: The time when a transit vehicle is available to the public; it is also known as revenue service hours (NTD, 2012).

Operating Speed: This analysis applies operating speeds of between 10 to 14 miles per hour. Buses and street transit in central city areas commonly have an operating speed of 7.5 to $12.5 \mathrm{mph}$. Buses in the suburbs have operating speeds of 9.3 to $15.5 \mathrm{mph}$. Jacques and Levinson (1997) have also calculated the average operating speed of peak-hour bus travel to be around $14 \mathrm{mph}$. Assuming shuttles operate at roughly the same speed as buses, automobile travel is about 1.5 times faster than shuttles. The analysis revealed that car speeds are consistently 1.4 to 1.6 times as fast as bus speeds (Jacques and Levinson, 1997). Therefore, a shuttle operating at 14 miles per hour corresponds with a car operating at 22 miles per hour. Peak-hour bus travel times are approximately 4.2 minutes per mile in the suburbs (approximately $14 \mathrm{mph}$ ), 6.0 minutes per mile in the city (10 $\mathrm{mph}$ ), and 11.50 minutes per mile in the CBD. TCRP 26 makes use of a $4 \mathrm{ft} / \mathrm{sec}^{\wedge} 2$ acceleration and deceleration rate for calculations. 
Passengers per Hour: The number of passengers that have boarded a transit vehicle over one hour. It is a common metric to determine the effectiveness of service through the number of passengers. An indicator for normal shuttle operations in a low ridership density setting is 10 to 17 persons per hour (Transit Resource Center, 2004). Between 2002 and 2008, Tri Delta Transit has observed 14.5 to 15.5 passengers per hour, averaged among all bus routes (ECCTA, 2008), although bus route typically have higher passenger counts than shuttles.

\section{Service Options:}

- "Weekday AM and PM Peak Only": Service operates for 3 hours in the AM peak from 6:30 am to 9:30 am and 3 hours in the PM peak from 3:30 pm to $6: 30 \mathrm{pm}$.

- "Weekday All Day": Service operates at the shortest possible headways using one vehicle per route for 12 hours from $6: 30$ am to $6: 30 \mathrm{pm}$.

- "Weekday AM and PM Peak, Plus Weekend All Day": Service operates for 3 hours in the AM peak and 3 hours in the PM peak on weekdays. Service operates at the shortest possible headways using one vehicle per route for 10 hours on weekends from $11 \mathrm{am}$ to $9 \mathrm{pm}$.

- "Weekday All Day with $\mathbf{3 0}$ Minute Peak Headways": Service operates at 30 minute headways during the AM peak (6:30 am to 9:30 am), midday peak (11:30 am to 1:30 pm), and PM peak (3:30 to 6:30). For offpeak headways, service operates at the shortest possible headways using one vehicle per route. 
Shuttle: A public transportation service that serves short local trips connecting major activity centers or other transportation terminals. Shuttle and circulator routes exhibit the following attributes (Regional Transportation District, 2008):

- Routes are less than 10 miles long.

- Vehicles operate on local streets and arterials.

- Circulators serve local trips in a community.

- Shuttles are connectors between major activity centers.

- Shuttles can serve as "first-mile" or "last-mile" links through station-to-work or station-to-home connections.

Vehicle Revenue Hours: Hours that vehicles are scheduled to travel while in service (NTD, 2012).

Vehicle Revenue Miles: Miles that vehicles are scheduled to travel while in service (NTD, 2012). 


\section{VIB. ALTERNATIVE PLAN 1: RAILROAD AVENUE ROUTE}

This proposal examines the minimum service provided by a shuttle operating along Railroad Avenue. A shuttle along the Railroad Avenue route provides a direct public transportation connection between two large commercial areas oriented towards different shopping needs. The burgeoning growth from new businesses in the Old Town area has attracted shoppers into this north Railroad Avenue node. New residential units and existing homes in the Old Town area create travel demand for the grocery stores and everyday retail establishments around the city. The south Railroad Avenue node, the area around Atlantic Plaza Shopping Center, features large commercial establishments with several supermarkets and pharmacies. As the number of visitors and residents to this growing area increase, the number of trips will also increase. The Railroad Avenue corridor would provide the most basic form of shuttle service between major commercial areas of Old Town and Atlantic Plaza Shopping Center.

\section{ROUTE PLANNING}

The Railroad Avenue route, connecting the Pittsburg Marina with Atlantic Plaza Shopping Center, is 2.6 miles. Figure 12 shows the location of proposed transit stops that have been selected based on locations of greatest potential attraction or trip production. The total stop-to-stop distance, shown in Table 15, breaks down the miles traveled along the route. As an example, a trip from the "Marina" stop to the "Marina Housing" stop is 0.4 miles. 
Figure 12. ALTERNATIVE 1 - RAILROAD AVENUE ROUTE: ROUTES AND STOPS

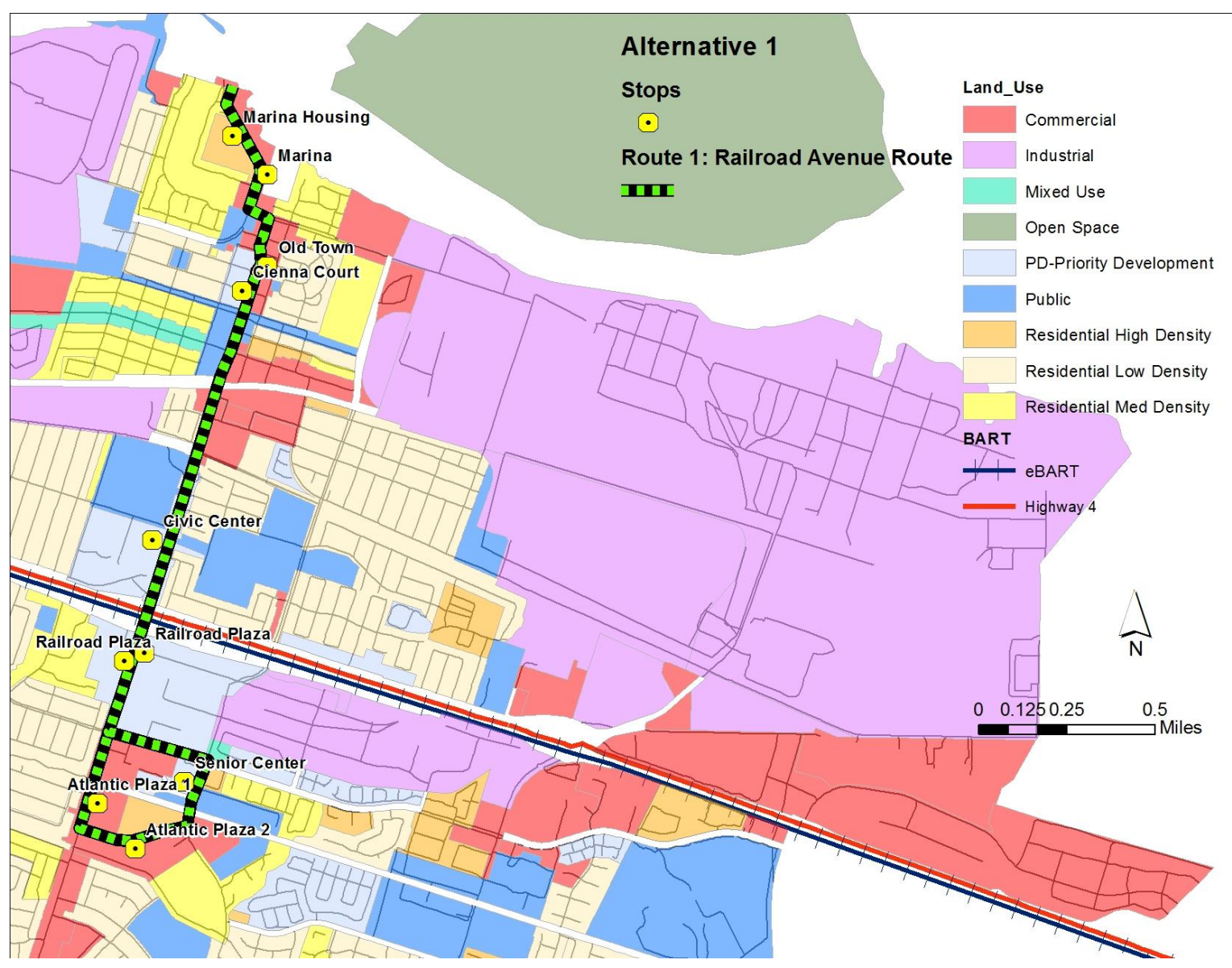

Table 15. RAILROAD AVENUE ROUTE: MILES BETWEEN STOPS

\begin{tabular}{|c|c|c|c|c|c|c|c|c|c|c|}
\hline & $\begin{array}{l}\text { Marina } \\
\text { Housing }\end{array}$ & $\begin{array}{l}\text { Siena } \\
\text { Court }\end{array}$ & $\begin{array}{l}\text { Civic } \\
\text { Center }\end{array}$ & $\begin{array}{l}\text { Railroad } \\
\text { Plaza }\end{array}$ & $\begin{array}{l}\text { Senior } \\
\text { Center }\end{array}$ & $\begin{array}{l}\text { Atlantic } \\
\text { Plaza } 1 \\
\end{array}$ & $\begin{array}{l}\text { Atlantic } \\
\text { Plaza } 2\end{array}$ & $\begin{array}{l}\text { Railroad } \\
\text { Ave }\end{array}$ & \begin{tabular}{|l|} 
Old \\
Town \\
\end{tabular} & Marina \\
\hline Marina & 0.4 & 0.9 & 1.7 & 2.3 & 2.8 & 3.4 & 3.4 & 3.8 & 4.9 & 5.2 \\
\hline Marina Housing & & 0.5 & 1.3 & 1.8 & 2.4 & 2.7 & 2.9 & 3.4 & 4.5 & 4.8 \\
\hline Siena Court & & & 0.8 & 1.3 & 1.9 & 2.2 & 2.4 & 2.9 & 4.0 & 4.3 \\
\hline Civic Center & & & & 0.5 & 1.1 & 1.4 & 1.6 & 2.1 & 3.2 & 3.5 \\
\hline Railroad Plaza & & & & & 0.6 & 0.9 & 1.1 & 1.6 & 2.7 & 3.0 \\
\hline Senior Center & & & & & & 0.3 & 0.5 & 1.0 & 2.1 & 2.4 \\
\hline Atlantic Plaza 1 & & & & & & & 0.2 & 0.7 & 1.8 & 2.1 \\
\hline Atlantic Plaza 2 & & & & & & & & 0.5 & 1.6 & 1.9 \\
\hline Railroad Ave & & & & & & & & & 1.1 & 1.4 \\
\hline Old Town & & & & & & & & & & 0.3 \\
\hline
\end{tabular}


To cover this 2.6-mile stretch, several assumptions are made to match required vehicle speeds with desired total travel time. Table 16 shows the expected in-vehicle travel time to provide a sense of time in transit from the passenger's perspective. It also reflects a planned stop-to-stop travel time standard that will need to be maintained in order to meet half-hour headways. One shuttle can provide transit service on 30-minute headways. The shuttle's ability to meet this target assumes that an average speed of 14 miles per hour will need to be maintained. Details are included in Appendix Table A1.

Half-hour headways can be met with one vehicle along the Railroad Avenue route. The total in-vehicle travel time, calculated as the sum of travel times for each route segment, for the Railroad Avenue route is 22.0 minutes (Table 16). Each cell in the table is populated by the function below.

$$
T_{s}=\frac{v_{\max }}{2}\left(\frac{1}{a}+\frac{1}{b}\right)+\frac{S}{v_{\max }}
$$

\section{Where,}

$T_{S}$ is travel time between stations

$S$ [ft] is spacing greater than $S_{c}$

$v_{\max }$ is the maximum speed

$a$ [ft./sec ${ }^{\wedge}$ ] is acceleration rate

$b\left[\mathrm{ft} . / \mathrm{sec}^{\wedge} 2\right]$ is deceleration rate

The calculations for station-to-station travel time are shown in detail in Appendix A, section AB. An alternative method of calculation that estimates travel time for the route as a whole returns roughly the same results, with a 22.5 minute travel time for one cycle (Appendix Table A1). When factoring in a minimum terminal time (15 
percent of total travel time), the subtotal for minimum travel time becomes 25.9 minutes. Adding a 15-second passenger loading and unloading period for each stop, the shuttle is still able to meet the half hour headway. The total travel time for one cycle is 28.4 minutes.

Table 16. RAILROAD AVENUE ROUTE: TRANSIT IN-VEHICLE TRAVEL TIME (IN MINUTES)

\begin{tabular}{|c|c|c|c|c|c|c|c|c|c|c|}
\hline & $\begin{array}{l}\text { Marina } \\
\text { Housing }\end{array}$ & $\begin{array}{l}\text { Siena } \\
\text { Court }\end{array}$ & $\begin{array}{l}\text { Civic } \\
\text { Center }\end{array}$ & $\begin{array}{l}\text { Railroad } \\
\text { Plaza }\end{array}$ & $\begin{array}{l}\text { Senior } \\
\text { Center }\end{array}$ & $\begin{array}{l}\text { Atlantic } \\
\text { Plaza } 1 \\
\end{array}$ & $\begin{array}{l}\text { Atlantic } \\
\text { Plaza } 2 \\
\end{array}$ & $\begin{array}{l}\text { Railroad } \\
\text { Ave }\end{array}$ & $\begin{array}{l}\text { Old } \\
\text { Town }\end{array}$ & Marina \\
\hline Marina & 1.7 & 4.0 & 7.3 & 9.5 & 11.9 & 13.0 & 14.0 & 15.9 & 20.7 & 22.0 \\
\hline Marina Housing & & 2.2 & 5.6 & 7.7 & 10.1 & 11.3 & 12.3 & 14.2 & 19.0 & 20.3 \\
\hline Siena Court & & & 3.4 & 5.5 & 7.9 & 9.1 & 10.1 & 12.0 & 16.8 & 18.0 \\
\hline Civic Center & & & & 2.1 & 4.5 & 5.7 & 6.7 & 8.6 & 13.4 & 14.7 \\
\hline Railroad Plaza & & & & & 2.4 & 3.6 & 4.6 & 6.5 & 11.3 & 12.5 \\
\hline Senior Center & & & & & & 1.2 & 2.2 & 4.1 & 8.9 & 10.1 \\
\hline Atlantic Plaza 1 & & & & & & & 1.0 & 2.9 & 7.7 & 9.0 \\
\hline Atlantic Plaza 2 & & & & & & & & 1.9 & 6.7 & 8.0 \\
\hline Railroad Ave & & & & & & & & & 4.8 & 6.1 \\
\hline Old Town & & & & & & & & & & 1.3 \\
\hline
\end{tabular}

Several assumptions are made in the calculation of station-to-station travel time. Equations estimating station-to-station travel time used in the calculation of Table 16 can be found in Appendix Table A3. Equations are based on travel time principles described in the Institute of Transportation Engineers Transportation Planning Handbook, where travel time is determined as a function of speed, acceleration, and distance. The spacing between stops is sufficient for vehicles to meet the desired speeds of $14 \mathrm{mph}$. Because stop spacing is greater than a quarter mile, the shuttle should be able to achieve speeds at the higher end of typical transit vehicle ranges. It is reasonable to think that 14 miles per hour should be a manageable average operating speed, but future vehicle on-road performances should be conducted to confirm this assumption. 
In-vehicle travel time of a shuttle can be compared to the time it takes to drive between the same stop locations. Table 17 shows the difference between transit travel time and automobile travel time under the assumption that drivers on Railroad Avenue would travel at an average speed of 25 miles per hour. A look at the difference reveals the travel time savings made by an automobile trip is noticeable but not large. There is only a 5-minute difference between a one-way trip from one end of the Railroad Avenue route, the "Marina" stop in the Old Town area, and the other end of the route, the "Atlantic 1" stop in the Atlantic Plaza Shopping Center area. With shorter trips, the travel time differences become even smaller. Table 18 shows the out-of-pocket cost for automobile travel compared to a potential fare of one dollar. Table 17 and Table 18 provide points of consideration between the travel time savings and travel cost savings.

Table 17. RAILROAD AVENUE ROUTE: DIFFERENCE IN TRAVEL TIME BETWEEN AUTOMOBILE AND TRANSIT (IN MINUTES)

\begin{tabular}{|c|c|c|c|c|c|c|c|c|c|c|}
\hline & \begin{tabular}{|l|} 
Marina \\
Housing \\
\end{tabular} & \begin{tabular}{|l} 
Siena \\
Court
\end{tabular} & \begin{tabular}{|l|} 
Civic \\
Center \\
\end{tabular} & \begin{tabular}{|l|} 
Railroad \\
Plaza \\
\end{tabular} & \begin{tabular}{|l|} 
Senior \\
Center
\end{tabular} & \begin{tabular}{|l|} 
Atlantic \\
Plaza 1 \\
\end{tabular} & \begin{tabular}{|l|} 
Atlantic \\
Plaza 2 \\
\end{tabular} & $\begin{array}{l}\text { Railroad } \\
\text { Ave } \\
\end{array}$ & $\begin{array}{l}\text { Old } \\
\text { Town }\end{array}$ & Marina \\
\hline Marina & 0.7 & 1.7 & 3.1 & 4.1 & 5.1 & 5.0 & 6.0 & 6.8 & 8.9 & 9.4 \\
\hline Marina Housing & & 1.0 & 2.4 & 3.3 & 4.3 & 4.8 & 5.2 & 6.1 & 8.1 & 8.7 \\
\hline Siena Court & & & 1.5 & 2.4 & 3.4 & 3.9 & 4.3 & 5.1 & 7.2 & 7.7 \\
\hline Civic Center & & & & 0.9 & 1.9 & 2.4 & 2.8 & 3.6 & 5.7 & 6.3 \\
\hline Railroad Plaza & & & & & 1.0 & 1.5 & 1.9 & 2.7 & 4.8 & 5.4 \\
\hline Senior Center & & & & & & 0.5 & 0.9 & 1.7 & 3.8 & 4.3 \\
\hline Atlantic Plaza 1 & & & & & & & 0.4 & 1.2 & 3.3 & 3.8 \\
\hline Atlantic Plaza 2 & & & & & & & & 0.8 & 2.9 & 3.4 \\
\hline Railroad Ave & & & & & & & & & 2.1 & 2.6 \\
\hline Old Town & & & & & & & & & & 0.5 \\
\hline
\end{tabular}


Table 18. RAILROAD AVENUE ROUTE: OUT-OF-POCKET COSTS FOR DRIVING (IN DOLLARS)

\begin{tabular}{|c|c|c|c|c|c|c|c|c|c|c|}
\hline & $\begin{array}{l}\text { Marina } \\
\text { Housing }\end{array}$ & $\begin{array}{l}\text { Siena } \\
\text { Court }\end{array}$ & $\begin{array}{l}\text { Civic } \\
\text { Center }\end{array}$ & $\begin{array}{l}\text { Railroad } \\
\text { Plaza } \\
\end{array}$ & $\begin{array}{l}\text { Senior } \\
\text { Center }\end{array}$ & $\begin{array}{l}\text { Atlantic } \\
\text { Plaza } 1\end{array}$ & $\begin{array}{l}\text { Atlantic } \\
\text { Plaza } 2\end{array}$ & $\begin{array}{l}\text { Railroad } \\
\text { Ave }\end{array}$ & $\begin{array}{l}\text { Old } \\
\text { Town }\end{array}$ & Marina \\
\hline Marina & 0.25 & 0.56 & 1.04 & 1.34 & 1.68 & 2.00 & 2.00 & 2.27 & 2.95 & 3.13 \\
\hline Marina Housing & & 0.32 & 0.79 & 1.09 & 1.43 & 1.60 & 1.75 & 2.02 & 2.70 & 2.88 \\
\hline Siena Court & & & 0.47 & 0.78 & 1.12 & 1.29 & 1.43 & 1.70 & 2.38 & 2.56 \\
\hline Civic Center & & & & 0.30 & 0.64 & 0.81 & 0.96 & 1.23 & 1.91 & 2.09 \\
\hline Railroad Plaza & & & & & 0.34 & 0.51 & 0.65 & 0.93 & 1.60 & 1.78 \\
\hline Senior Center & & & & & & 0.17 & 0.32 & 0.59 & 1.26 & 1.44 \\
\hline Atlantic Plaza 1 & & & & & & & 0.15 & 0.42 & 1.09 & 1.28 \\
\hline Atlantic Plaza 2 & & & & & & & & 0.27 & 0.95 & 1.13 \\
\hline Railroad Ave & & & & & & & & & 0.68 & 0.86 \\
\hline Old Town & & & & & & & & & & 0.18 \\
\hline
\end{tabular}

\section{TRIP CALCULATION}

Average daily trips are calculated by 1) using inputs from survey data and applying weight factors to normalize the survey's population distribution with the actual population distribution; 2) determining the population of potential transit riders in the route service area; and 3) making further adjustments to account for special populations.

First, the basic calculation is made for weighted daily trips to a destination per person in an age group. The calculation takes the total weekly travel demand for each location in each age group and divides this total by the 7 days to get the average daily travel demand for each age group. This result is then multiplied by each age group's appropriate weighted factor to account for the disparity in population proportions between the sample and the actual population. Average daily trips are shown in Table 19. 
Weighted Daily Trips $=\frac{\frac{T}{R}}{7} * W f$

Where,

Weighted Daily Trips = daily trips per person in an age group per day with an applied weight

$T=$ total weekly number of trips made to each destination per age group (Figure 9)

$R=$ number of respondents per age group (Appendix Table B1)

$W f=$ weight factor: 0.94 for ages 25-44, 0.50 for ages 45-64, 0.60 for over 64 (Table 2)

Table 19. WEIGHTED DAILY TRIPS PER PERSON IN EACH AGE GROUP

\begin{tabular}{|l|r|r|r|r|}
\hline & \multicolumn{1}{|c|}{$25-44$} & \multicolumn{1}{c|}{$45-64$} & \multicolumn{1}{c|}{ Over 64 } & \multicolumn{1}{c|}{ Sum } \\
\hline Atlantic Plaza Shopping Center & \multicolumn{1}{|c|}{0.17} & \multicolumn{1}{|c|}{0.04} & 0.03 & 0.24 \\
\hline Century Plaza Shopping Center & 0.13 & 0.04 & 0.04 & 0.21 \\
\hline Civic Center (City Hall, Court House, Library) & 0.22 & 0.09 & 0.02 & 0.33 \\
\hline Hampton Inn (California Ave and Carion Ct) & 0.04 & 0.00 & 0.00 & 0.04 \\
\hline North Park Plaza (WinCo Foods) & 0.15 & 0.04 & 0.04 & 0.23 \\
\hline Old Town & 0.21 & 0.08 & 0.07 & 0.36 \\
\hline Pittsburg Marina & 0.08 & 0.04 & 0.04 & 0.16 \\
\hline Pittsburg/ Bay Point BART & 0.22 & 0.08 & 0.02 & 0.32 \\
\hline Senior Center (Presidio Ln) & 0.07 & 0.00 & 0.03 & 0.10 \\
\hline School (Pittsburg High, Marina Vista) & 0.03 & 0.03 & 0.01 & 0.07 \\
\hline Sum & 1.31 & 0.44 & 0.31 & 2.07 \\
\hline
\end{tabular}


Second, weighted daily trips are applied to the population of potential transit users. Weighted daily trips for each age group - population pair (represented in each cell of Table 19) are multiplied by the total population of that age group along the proposed transit route. Table 20 shows the resulting number of daily trips produced by the population along the transit route. Detailed spreadsheets of calculations are found in Appendix A, section AD.

Table 20. ALTERNATIVE 1: WEIGHTED DAILY TRIPS OF POPULATION NEAR SHUTTLE ROUTE

\begin{tabular}{|l|r|r|r|r|}
\hline & $25-44$ & $45-64$ & Over 64 & Sum \\
\hline Atlantic Plaza Shopping Center & 7 & 1 & 0 & 8 \\
\hline Century Plaza Shopping Center & 11 & 3 & 1 & 15 \\
\hline Civic Center (City Hall, Court House, Library) & 16 & 5 & 0 & 21 \\
\hline Hampton Inn (California Ave and Carion Ct) & 3 & 0 & 0 & 3 \\
\hline North Park Plaza (WinCo Foods) & 12 & 3 & 1 & 16 \\
\hline Old Town & 14 & 5 & 1 & 20 \\
\hline Pittsburg Marina & 6 & 3 & 1 & 9 \\
\hline Pittsburg/ Bay Point BART & 18 & 5 & 1 & 24 \\
\hline Senior Center (Presidio Ln) & 3 & 0 & 0 & 3 \\
\hline School (Pittsburg High, Marina Vista) & 2 & 1 & 0 & 4 \\
\hline Sum & 91 & 27 & 6 & 124 \\
\hline
\end{tabular}




$$
T=\operatorname{HBShop}(L * W)
$$

Where,

$T=$ potential transit trips to a destination

HBShop $=$ Home-based-shopping trip made by transit (4 percent of trips) *

$L=$ population of people in an age group living within $1 / 4$ mile of a shuttle route that would make trips (Appendix Table A11)

$W=$ weighted daily trips by age group (Table 14)

*Source: Contra Costa Transportation Authority (2003)

The variable $T$, from the equation above, is the potential number of one-way trips to a destination; it is applied in each cell of Table 19 and is the product of $W, H B S h o p$, and $L$. The weighted daily trips $(W)$ in Table 19 are multiplied by two factors. One factor in the equation is HBShop, the proportion of trips made by transit for the purposes of shopping and commercial activities (CCTA, 2003). Another factor is the population living within $1 / 4$ mile of a shuttle route that would make trips (the variable $L$ ), which refers to the people who would likely require some form of transportation to make a trip. In other words, the population of potential shuttle users is equal to the number of residents around a transit route excluding those who live in units where the origin and destination of a trip would be in the same area. For example, the population of trip makers that want to travel to the Atlantic Plaza Shopping Center area will contain all housing units within $1 / 4$ mile of the route minus all housing units immediately around the Atlantic Plaza area. This population is expressed as the following function. 


$$
L=P *[H *(U-A)]
$$

Where,

$L=$ population of people in an age group living within $1 / 4$ mile of a shuttle route that would make trips (Appendix Table A11)

$P=$ proportion of population in age group $(0.29$ for $25-44 ; 0.24$ for $45-63 ; 0.09$ for Over 64) (Census, 2010)

$H=$ average household size in Pittsburg (3.22)(Census, 2010)

$U=$ total housing units within $1 / 4$ mile of shuttle routes (2240) (Appendix Table A10) $A=$ total number of units in area of trip origin (Appendix Table A10)

Third, the total trips require more adjustments to account for various factors. Senior housing units are not included in the previous calculations because multiplying each senior housing unit by 3.22 , the average household size, would likely overestimate trips for these smaller living units. Instead, the number of daily trips from a senior housing unit to a destination (shown in Table 19) is multiplied by the number of senior units (with the assumption that each unit is occupied by one person who would make a trip), then by 0.04 (the proportion of trips made by transit). The additional daily trips for each destination are rounded then added to the sum trips calculated in Table 20 .

Some omissions were made due to the uncertainty of present conditions or survey responses. This alternative does not serve Century Plaza, Hampton Inn, or North Park Plaza, so trip values were set to zero. The ridership interested in the BART connection has also been omitted for now due to the unknown status of the eBART station on Railroad Avenue. The age group under 24 years old has also been omitted from the analysis due to the few responses received and the concern about overestimation or underestimation of needs. Other destinations not 
included in the final trip consideration are the senior center and schools. These locations are difficult to estimate based on the few responses from the survey. Furthermore, these locations are close to other locations that are represented: the senior center is near Atlantic Plaza Shopping Center and the schools are near Old Town. These nearby locations could serve as proxies to trips that would be made to the senior center and schools. Removing trips from the final ridership calculation is done to limit the effects of less reliable data. This analysis takes a more conservative approach in estimating ridership. After all adjustments, the number of passengers per day is 61 (or 122 trips). Figure 13 shows the daily trip distribution once all factors have been included, and Table 21 shows the break down.

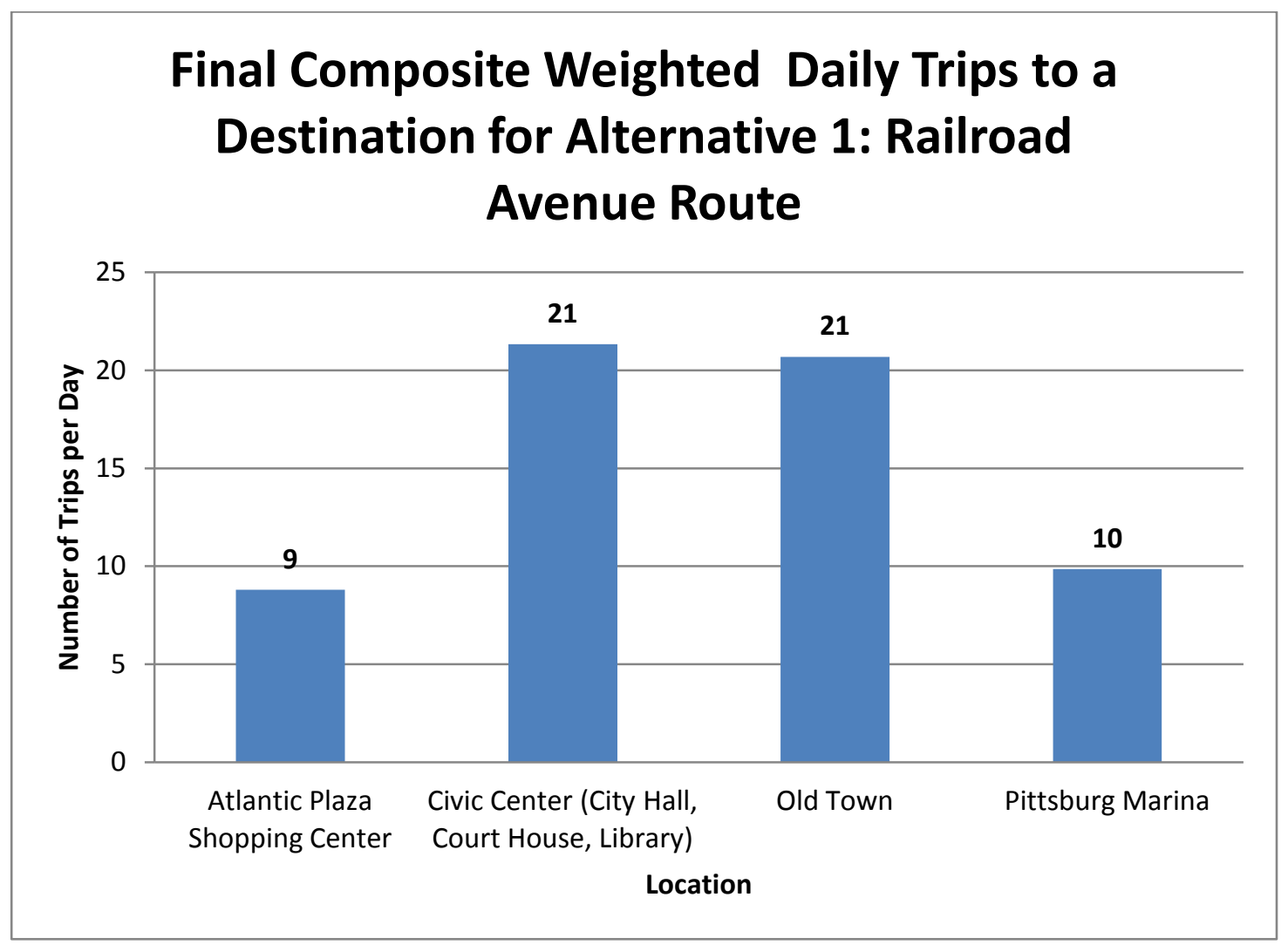


Table 21. ALTERNATIVE 1: FINAL COMPOSITE WEIGHTED DAILY TRIPS TO A DESTINATION

\begin{tabular}{|l|r|r|r|r|}
\hline & $25-44$ & $45-64$ & Over 64 & Sum \\
\hline Atlantic Plaza Shopping Center & 7 & 1 & 1 & 9 \\
\hline Century Plaza Shopping Center & 0 & 0 & 0 & 0 \\
\hline Civic Center (City Hall, Court House, Library) & 16 & 5 & 1 & 21 \\
\hline Hampton Inn (California Ave and Carion Ct) & 0 & 0 & 0 & 0 \\
\hline North Park Plaza (WinCo Foods) & 0 & 0 & 0 & 0 \\
\hline Old Town & 14 & 5 & 2 & 21 \\
\hline Pittsburg Marina & 6 & 3 & 1 & 10 \\
\hline Pittsburg/ Bay Point BART & 0 & 0 & 0 & 0 \\
\hline Senior Center (Presidio Ln) & 0 & 0 & 0 & 0 \\
\hline School (Pittsburg High, Marina Vista) & 0 & 0 & 0 & 0 \\
\hline Sum & 42 & 14 & 5 & 61 \\
\hline
\end{tabular}

Approximately 122 passenger trips are projected per day (assuming roundtrips for each of the 61 trips to a destination). Since 12 revenue service hours is considered "all day" service, passengers per hour can be calculated as 122 passengers per day divided by 12 hours. The resulting rate of 10 passengers per hour (pph) provides an hourly performance measure. More importantly, the rate provides a more appropriate means to calculate ridership over shorter operating periods. For example, "Weekday AM and PM Peak Only" service only operates for 6 hours per day and it may not be reasonable to expect 122 passengers (or 20 $\mathrm{pph}$ ) in those limited hours. Applying the hourly rate of $10 \mathrm{pph}$ creates a projection of 61 passengers per day, which is a more likely estimate than one that assumes all 122 potential daily riders would schedule their trips around very limited service hours. Overall, the range of ridership may be somewhere around $10 \mathrm{pph}$. It is in the lower range of the expected 10 to $17 \mathrm{pph}$ average, but the groups omitted in the study would likely bring the passenger boarding rates higher in the average range. 


\section{COST ANALYSIS}

Table 22 shows the additional required costs for shuttle operation after factoring in potential business contributions and fare revenues. The table adjusts the base costs presented in Table 6 of Evaluation of Costs to reflect the cost of service assuming some funding contributions and revenue recovery. These calculations assume a $\$ 25$ per month business contribution from 20 businesses each year, which totals $\$ 6,000$. Passenger fare revenues were calculated by multiplying the average number of passengers per day by the number of days per year, or the number of passengers per hour by the number of hours per year. The cost recovery is based on basic willingness-to=pay assumptions derived from the survey rather than alternative financing mechanisms.

At a one-dollar fare, some cost can be recovered but not enough to substantially offset the cost of operation. The "Weekday All Day" option, which operates 5 days per week for 50 week returns about $\$ 30,000$ per year from the 122 passengers per day. The "Weekday AM and PM Peak Only" option returns about $\$ 15,000$ per year from 10 passengers per hour times 6 hours per day for 250 weekdays. The "Weekday AM and PM Peak, Plus Weekend All Day" option, which operates on 6 peak hours every weekday and 2 days over the weekend for 50 weeks, returns about $\$ 27,000$ per year. Revenue recovery and business contributions for service do not substantially decrease annual operating costs, so providing the shuttles without fares may be an appropriate choice if providing benefits to the community are more important than minor cost recovery. 
Table 22. ALTERNATIVE 1: ANNUAL SHUTTLE COSTS MINUS BUSINESS CONTRIBUTION AND FARES

\begin{tabular}{|c|c|c|c|c|c|}
\hline & Fare: Free & $\$ 0.25$ & $\$ 0.50$ & $\$ 1$ \\
\hline \multirow{3}{*}{$\begin{array}{l}\text { Operating } \\
\text { Cost of } \\
\$ 60 \text { per } \\
\text { Hour }\end{array}$} & $\begin{array}{l}\text { Weekday AM and } \\
\text { PM Peak Only }\end{array}$ & $(\$ 84,000)$ & $(\$ 80,210)$ & $(\$ 76,419)$ & $(\$ 68,839)$ \\
\hline & $\begin{array}{l}\text { Weekday AM and } \\
\text { PM Peak, Plus } \\
\text { Weekend All Day }\end{array}$ & $(\$ 144,000)$ & $(\$ 137,177)$ & $(\$ 130,355)$ & $(\$ 116,710)$ \\
\hline & Weekday All Day & $(\$ 174,000)$ & $(\$ 166,419)$ & $(\$ 158,839)$ & $(\$ 143,678)$ \\
\hline \multirow{3}{*}{$\begin{array}{l}\text { Operating } \\
\text { Cost of } \\
\$ 70 \text { per } \\
\text { Hour }\end{array}$} & $\begin{array}{l}\text { Weekday AM and } \\
\text { PM Peak Only }\end{array}$ & $(\$ 99,000)$ & $(\$ 95,210)$ & $(\$ 91,419)$ & $(\$ 83,839)$ \\
\hline & $\begin{array}{l}\text { Weekday AM and } \\
\text { PM Peak, Plus } \\
\text { Weekend All Day }\end{array}$ & $(\$ 169,000)$ & $(\$ 162,177)$ & $(\$ 155,355)$ & $(\$ 141,710)$ \\
\hline & Weekday All Day & $(\$ 204,000)$ & $(\$ 196,419)$ & $(\$ 188,839)$ & $(\$ 173,678)$ \\
\hline \multirow{3}{*}{$\begin{array}{l}\text { Operating } \\
\text { Cost of } \\
\$ 80 \text { per } \\
\text { Hour }\end{array}$} & $\begin{array}{l}\text { Weekday AM and } \\
\text { PM Peak Only }\end{array}$ & $(\$ 114,000)$ & $(\$ 110,210)$ & $(\$ 106,419)$ & $(\$ 98,839)$ \\
\hline & $\begin{array}{l}\text { Weekday AM and } \\
\text { PM Peak, Plus } \\
\text { Weekend All Day }\end{array}$ & $(\$ 194,000)$ & $(\$ 187,177)$ & $(\$ 180,355)$ & $(\$ 166,710)$ \\
\hline & Weekday All Day & $(\$ 234,000)$ & $(\$ 226,419)$ & $(\$ 218,839)$ & $(\$ 203,678)$ \\
\hline
\end{tabular}

\section{ADDITIONAL CONSIDERATIONS IN ABSENCE OF EBART}

With the current funding source for the eBART extension still in question, this section presents a plan to connect the shuttle with existing BART facilities. If there is immediate interest to move forward with the shuttle project before the outcome of the eBART station has been decided, a route will need to expand westward towards the Pittsburg/Bay Point BART station. The Railroad Avenue configuration will remain the same but an additional east-west route will transport passengers between Railroad Avenue and BART during peak times. A route to the Pittsburg/ Bay Point BART station would be approximately 3.6 miles long. A vehicle traveling at least $11 \mathrm{mph}$ can meet one-hour headways. If a connection to 
BART is available during peak travel times of $6: 30 \mathrm{am}$ to $9: 30 \mathrm{am}$ and $3: 30 \mathrm{pm}$ to 6:30 pm, the additional cost that would be added to each operating cost scenario is represented in the following function. The revised total annual costs for each operating cost scenario are shown in Table 23.

Additional Annual Cost for BART AM and PM Peak Connection

$$
\begin{aligned}
& =\text { Operating Cost per Hour } * 6 \frac{h r s}{\text { day }} * 5 \frac{\text { days }}{\text { week }} * 50 \frac{\text { weeks }}{\text { year }} \\
& -24 \frac{\text { additional passengers }}{\text { day }} * 250 \frac{\text { weekdays }}{\text { year }} * \text { fare }
\end{aligned}
$$

Table 23. ANNUAL SHUTTLE COSTS MINUS BUSINESS CONTRIBUTION AND FARES WITH ADDITIONAL BART

\begin{tabular}{|c|c|c|c|c|c|}
\hline & Fare: Free & $\$ 0.25$ & $\$ 0.50$ & $\$ 1$ \\
\hline \multirow{3}{*}{$\begin{array}{l}\text { Operating } \\
\text { Cost of } \\
\$ 60 \text { per } \\
\text { Hour }\end{array}$} & $\begin{array}{l}\text { Weekday AM and } \\
\text { PM Peak Only }\end{array}$ & $(\$ 93,000)$ & $(\$ 95,210)$ & $(\$ 91,419)$ & $(\$ 83,839)$ \\
\hline & $\begin{array}{l}\text { Weekday AM and } \\
\text { PM Peak, Plus } \\
\text { Weekend All Day }\end{array}$ & $(\$ 153,000)$ & $(\$ 152,177)$ & $(\$ 145,355)$ & $(\$ 131,710)$ \\
\hline & Weekday All Day & $(\$ 183,000)$ & $(\$ 181,419)$ & $(\$ 173,839)$ & $(\$ 158,678)$ \\
\hline \multirow{3}{*}{$\begin{array}{l}\text { Operating } \\
\text { Cost of } \\
\$ 70 \text { per } \\
\text { Hour }\end{array}$} & $\begin{array}{l}\text { Weekday AM and } \\
\text { PM Peak Only }\end{array}$ & $(\$ 110,500)$ & $(\$ 112,710)$ & $(\$ 108,919)$ & $(\$ 101,339)$ \\
\hline & $\begin{array}{l}\text { Weekday AM and } \\
\text { PM Peak, Plus } \\
\text { Weekend All Day }\end{array}$ & $(\$ 180,500)$ & $(\$ 179,677)$ & $(\$ 172,855)$ & $(\$ 159,210)$ \\
\hline & Weekday All Day & $(\$ 215,500)$ & $(\$ 213,919)$ & $(\$ 206,339)$ & $(\$ 191,178)$ \\
\hline \multirow{3}{*}{$\begin{array}{l}\text { Operating } \\
\text { Cost of } \\
\$ 80 \text { per } \\
\text { Hour }\end{array}$} & $\begin{array}{l}\text { Weekday AM and } \\
\text { PM Peak Only }\end{array}$ & $(\$ 128,000)$ & $(\$ 130,210)$ & $(\$ 126,419)$ & $(\$ 118,839)$ \\
\hline & $\begin{array}{l}\text { Weekday AM and } \\
\text { PM Peak, Plus } \\
\text { Weekend All Day }\end{array}$ & $(\$ 208,000)$ & $(\$ 207,177)$ & $(\$ 200,355)$ & $(\$ 186,710)$ \\
\hline & Weekday All Day & $(\$ 248,000)$ & $(\$ 246,419)$ & $(\$ 238,839)$ & $(\$ 223,678)$ \\
\hline
\end{tabular}
CONNECTION 


\section{VIC. ALTERNATIVE PLAN 2: CENTURY PLAZA ROUTE C}

This plan incorporates all elements of Alternative 1, creating a north-south transit route between Old Town and Atlantic Plaza, but expanding the system by adding an east-west route to Century Plaza. Figure 14 shows the proposed routes. Table 24 shows the miles between stops along the Century Plaza route (the Railroad Avenue route is covered in Alternative 1 and remains the same in this alternative). This configuration provides more travel options for visitors and residents. At Civic Center, a transfer center between the Railroad Avenue route and the Century Plaza route would link the attractions of Old Town area and the general shopping opportunities of Atlantic Plaza with the larger scale big-box stores and entertainment options of North Park Plaza and Century Plaza.

The extension of eBART service to Railroad Avenue would open up even more opportunities to promote transit use. Bart riders brought to Pittsburg would receive transit service to shopping and entertainment opportunities in Old Town. The route along Railroad Avenue will form a connection between the Old Town and the Atlantic Plaza to fulfill all shopping needs; this public transportation link to the Old Town area will be established for the proposed Transit Village Area as mentioned in the Railroad Avenue Specific Plan. The connection to Century Plaza will also be possible via a transfer between the Railroad Avenue route and the Century Plaza route at the Civic Center. 
Figure 14. ALTERNATIVE 2 - CENTURY PLAZA ROUTE C: ROUTES AND STOPS

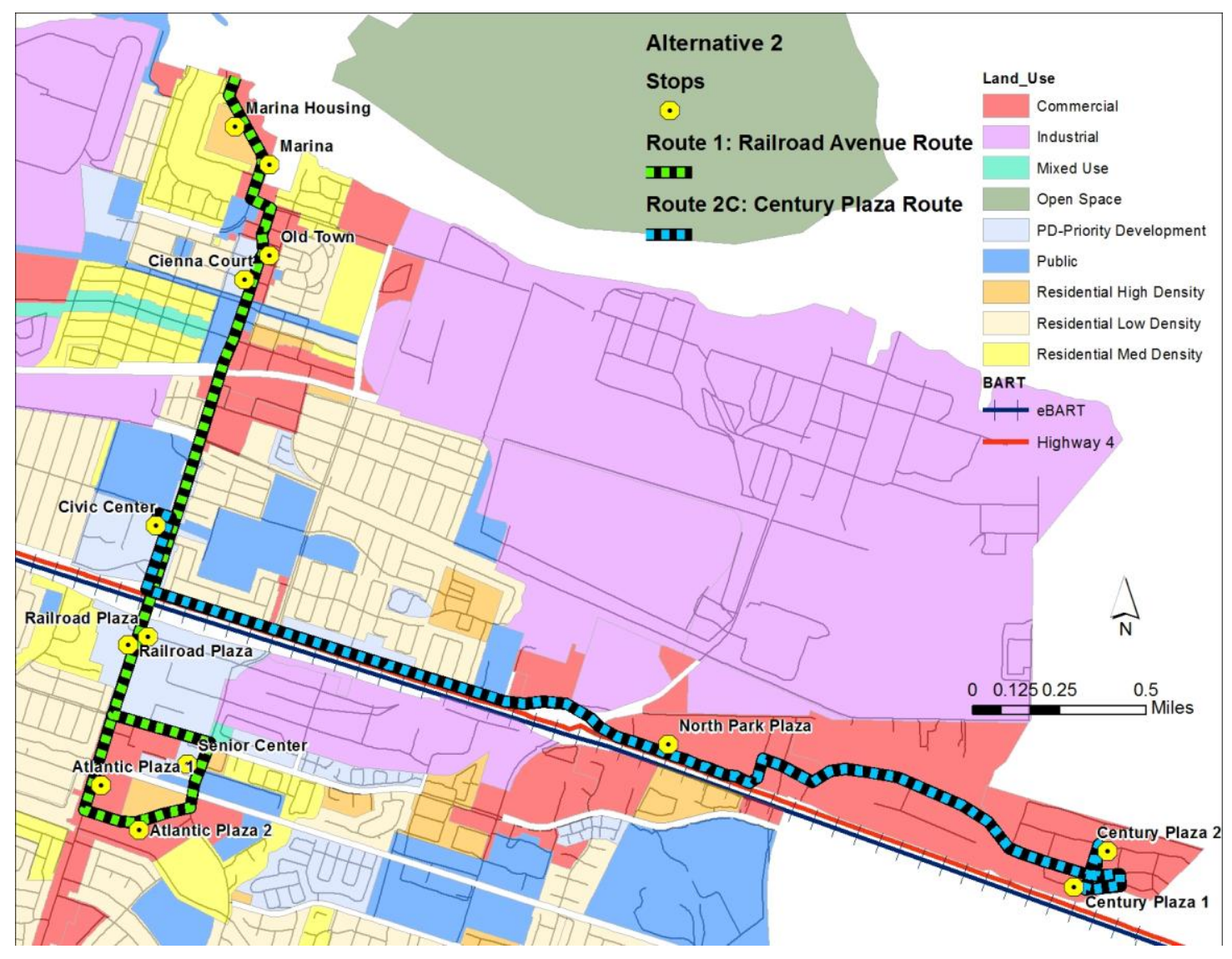

Table 24. CENTURY PLAZA ROUTE C: MILES BETWEEN STOPS

\begin{tabular}{|l|l|l|r|r|r|}
\hline & $\begin{array}{l}\text { North Park } \\
\text { Plaza }\end{array}$ & $\begin{array}{l}\text { Century } \\
\text { Plaza 1 }\end{array}$ & $\begin{array}{l}\text { Century } \\
\text { Plaza 2 }\end{array}$ & $\begin{array}{l}\text { North Park } \\
\text { Plaza }\end{array}$ & $\begin{array}{l}\text { Civic } \\
\text { Center }\end{array}$ \\
\hline Civic Center & 2.0 & 3.4 & 3.8 & 5.2 & 7.2 \\
\hline NorthPark Plaza & & 1.4 & 1.7 & 3.2 & 5.2 \\
\hline Century Plaza 1 & & & 0.3 & 1.7 & 3.8 \\
\hline Century Plaza 2 & & & & 1.4 & 3.4 \\
\hline North Park Plaza & & & & & 2.0 \\
\hline
\end{tabular}




\section{ROUTE PLANNING}

This section primarily covers the Century Plaza route in terms of route planning characteristics because the Railroad Avenue route is unchanged from the proposal described in Alternative 1.The Railroad Avenue route is 2.6 miles in one direction (5.2 miles for a full cycle) connecting the Pittsburg Marina with Atlantic Plaza Shopping Center. Shuttles traveling at 14 miles per hour are capable of meeting headways of 30 minutes with one vehicle.

The Century Plaza route is a 3.6-mile stretch. Table 24 shows the distance between stops along the full 7.2-mile cycle of a complete route. To cover this 7.2-mile stretch, several assumptions are made to match required vehicle speeds with desired travel time. Table 25 shows the expected in-vehicle travel time to provide a sense of time in transit from the passenger's perspective. It also reflects a planned stop-to-stop travel time standard that will need to be maintained in order to meet one-hour headways. One shuttle can provide transit service on 60 -minute headways but two shuttles will be required to meet half-hour headways during peak hours. The shuttle's ability to meet the target assumes that an average speed of 10 miles per hour will be maintained. Details are included in Appendix Table A1.

One-hour headways can be met with one vehicle along the Century Plaza route. The total in-vehicle travel time, calculated as the sum of travel times for each route segment, for the Century Plaza route is 42.5 minutes (Table 25). Each cell in the table is populated by the function below. 


$$
T_{s}=\frac{v_{\max }}{2}\left(\frac{1}{a}+\frac{1}{b}\right)+\frac{S}{v_{\max }}
$$

Where,

$T_{S}$ is travel time between stations

$S$ [ft] is spacing greater than $S_{c}$

$v_{\max }$ is the maximum speed

$a$ [ft./sec $\left.{ }^{\wedge} 2\right]$ is acceleration rate

$b\left[\mathrm{ft} . / \mathrm{sec}^{\wedge} 2\right]$ is deceleration rate

The calculations for station-to-station travel time are shown in detail in Appendix A, section AB. An alternative method of calculation that estimates travel time for the route as a whole returns roughly the same results, with a 43.2-minute travel time for one cycle (Appendix Table A1). When factoring in a minimum terminal time (15 percent of total travel time), the subtotal for minimum travel time becomes 49.7 minutes. Adding a 15-second passenger loading and unloading period for each stop, the shuttle is still able to meet the half hour headway. The total travel time for one cycle is 51 minutes.

Several assumptions are made in the calculation of station-to-station travel time. Equations estimating station-to-station travel time used in the calculation of Table 25 can be found in Appendix Table A4. Equations are determined as a function of speed, acceleration, and distance. The spacing between stops is sufficient for vehicles to meet the desired speeds of $10 \mathrm{mph}$. Future vehicle on-road performances should be conducted to confirm this assumption. 
Table 25. CENTURY PLAZA ROUTE C: TRANSIT IN VEHICLE TRAVEL TIME (IN MINUTES)

\begin{tabular}{|l|l|l|l|l|l|}
\hline & $\begin{array}{l}\text { North Park } \\
\text { Plaza }\end{array}$ & $\begin{array}{l}\text { Century } \\
\text { Plaza 1 }\end{array}$ & $\begin{array}{l}\text { Century } \\
\text { Plaza 2 }\end{array}$ & $\begin{array}{l}\text { North Park } \\
\text { Plaza }\end{array}$ & \multicolumn{1}{l|}{$\begin{array}{l}\text { Civic } \\
\text { Center }\end{array}$} \\
\hline Civic Center & 11.9 & 20.4 & 22.1 & 30.6 & 42.5 \\
\hline NorthPark Plaza & & 8.5 & 10.2 & 18.7 & 30.6 \\
\hline Century Plaza 1 & & & 1.7 & 10.2 & 22.1 \\
\hline Century Plaza 2 & & & & 8.5 & 20.4 \\
\hline North Park Plaza & & & & & 11.9 \\
\hline
\end{tabular}

\section{ALTERNATIVE OPERATING SPEEDS AND HEADWAYS}

Although $10 \mathrm{mph}$ is used, speeds up to $14 \mathrm{mph}$ are also feasible but require some additional considerations. This proposal uses $10 \mathrm{mph}$ in its calculations of travel time because it is within range of average shuttle speed. It is also easier to accommodate speeds that are above estimates than making adjustments to meet schedules due to speeds that are lower than expected.

From the passengers' perspective, an increase in operating speed from 10 mph to $14 \mathrm{mph}$ cuts difference between automobile and transit travel time by about 3 minutes, when comparing Table 26 and Table 27. Although the increase in speed improves passenger travel time, it decreases the efficiency of the route and creates long dwell times at the end of the trip. 


$$
Y=\frac{T T_{\min }}{h}
$$

Where,

$Y=$ scheduling efficiency

$T T_{\min }=$ minimum travel time

$h=$ desired headway

$$
T T_{\min } 10 \mathrm{mph}=\frac{2 L}{V}+\text { rest }=\frac{7.2 \mathrm{mi}}{10 \mathrm{mph}} * 60 \mathrm{~min} / \mathrm{h}+0.15 *\left(\frac{7.2 \mathrm{mi}}{10 \mathrm{mph}} * 60 \mathrm{~min} / \mathrm{h}\right)=49.7 \mathrm{~min}
$$

Schedule efficiency for shuttle operating at $10 \mathrm{mph}: \quad Y 10=\frac{49.7}{60}=0.83$

$$
T T_{\min } 14 \mathrm{mph}=\frac{2 L}{V}+r e s t=\frac{7.2 \mathrm{mi}}{14 \mathrm{mph}} * 60 \mathrm{~min} / \mathrm{h}+0.15 *\left(\frac{7.2 \mathrm{mi}}{14 \mathrm{mph}} * 60 \mathrm{~min} / \mathrm{h}\right)=35.5 \mathrm{~min}
$$

Schedule efficiency for shuttle operating at $14 \mathrm{mph}: \quad Y 14=\frac{35.5}{60}=0.59$

Scheduling efficiency can be increased either by lowering speeds (not recommended because it increases passenger in-vehicle travel time) or increasing travel speed to levels that can meet 30-minute headways. At the rate of 10 miles per hour, a shuttle completes a round trip between the Civic Center and Century Plaza in about 51 minutes, accounting for in-vehicle travel time, passenger boarding, and required rest time. A headway of 60 minutes is required. To attain headways of 30 minutes with one vehicle, a shuttle will need to reach an average speed of at least $18 \mathrm{mph}$. The speed is outside the average range for shuttles, which may indicate that it would be impractical. 
A moderate increase in design speed from 10 miles per hour to 14 miles per hour is within the typical range of shuttle speeds and can improve schedule efficiency if headways are also changed. The appeal of the 30 minute/ 60 minute headway increment is the simplicity to passengers. Headways on the Century Plaza route can be changed to 45 minutes instead of 60 minutes to maintain lower headways and increase the total number of trips that can be made in a day. This method comes at a cost of reduced clarity in transit scheduling for passengers because a 30 minute headway for Railroad Avenue route and a 45 minute headway for the Century Plaza route, makes it more difficult for passengers to remember transit arrival times at different increments. Schedule synchronization between the two routes can also be harder to manage. The decision comes to a choice between scheduling efficiency or shorter headways.

Table 26. CENTURY PLAZA ROUTE C: DIFFERENCE IN TRAVEL TIME BETWEEN AUTOMOBILE AND 10 MPH TRANSIT (IN MINUTES)

\begin{tabular}{|l|l|r|r|r|r|}
\hline & $\begin{array}{l}\text { North } \\
\text { Park } \\
\text { Plaza }\end{array}$ & $\begin{array}{l}\text { Century } \\
\text { Plaza 1 }\end{array}$ & $\begin{array}{l}\text { Century } \\
\text { Plaza 2 }\end{array}$ & $\begin{array}{l}\text { North } \\
\text { Park } \\
\text { Plaza }\end{array}$ & $\begin{array}{l}\text { Civic } \\
\text { Center }\end{array}$ \\
\hline Civic Center & 7.1 & 12.2 & 13.1 & 18.2 & 25.3 \\
\hline NorthPark Plaza & & 5.1 & 6.0 & 11.1 & 18.2 \\
\hline Century Plaza 1 & & & 1.0 & 6.0 & 13.1 \\
\hline Century Plaza 2 & & & & 5.1 & 12.2 \\
\hline North Park Plaza & & & & & 7.1 \\
\hline
\end{tabular}


Table 27. CENTURY PLAZA ROUTE C: DIFFERENCE IN TRAVEL TIME BETWEEN AUTOMOBILE AND 14 MPH TRANSIT (IN MINUTES)

\begin{tabular}{|l|l|r|r|r|r|}
\hline & $\begin{array}{l}\text { North } \\
\text { Park } \\
\text { Plaza }\end{array}$ & $\begin{array}{l}\text { Century } \\
\text { Plaza 1 }\end{array}$ & $\begin{array}{l}\text { Century } \\
\text { Plaza 2 }\end{array}$ & $\begin{array}{l}\text { North } \\
\text { Park } \\
\text { Plaza }\end{array}$ & $\begin{array}{l}\text { Civic } \\
\text { Center }\end{array}$ \\
\hline Civic Center & 3.7 & 8.8 & 9.8 & 14.8 & 21.9 \\
\hline NorthPark Plaza & & 5.1 & 6.0 & 11.1 & 18.2 \\
\hline Century Plaza 1 & & & 1.0 & 6.0 & 13.1 \\
\hline Century Plaza 2 & & & & 5.1 & 12.2 \\
\hline North Park Plaza & & & & & 7.1 \\
\hline
\end{tabular}

The cost of automobile travel along the Century Boulevard route is higher than shuttle fare for most trips. A one-dollar fare is comparable to the cost of travel between stops, shown in Table 28. The cost of automobile travel is 59.6 cents per mile, as described by Pritchett (2012), times the number of miles between stops. Although travel by shuttle would be less expensive, Table 26 and Table 27 show that travel time is much higher by shuttle. The choice of transit is determined by the relative importance each person places on time and cost.

Table 28. CENTURY PLAZA ROUTE C: OUT-OF-POCKET COSTS FOR AUTOMOBILE TRAVEL (IN DOLLARS)

\begin{tabular}{|l|l|r|r|r|r|}
\hline & $\begin{array}{l}\text { North } \\
\text { Park } \\
\text { Plaza }\end{array}$ & $\begin{array}{l}\text { Century } \\
\text { Plaza 1 }\end{array}$ & $\begin{array}{l}\text { Century } \\
\text { Plaza 2 }\end{array}$ & $\begin{array}{l}\text { North } \\
\text { Park } \\
\text { Plaza }\end{array}$ & $\begin{array}{l}\text { Civic } \\
\text { Center }\end{array}$ \\
\hline Civic Center & 1.20 & 2.05 & 2.24 & 3.09 & 4.29 \\
\hline NorthPark Plaza & & 0.86 & 1.04 & 1.90 & 3.09 \\
\hline Century Plaza 1 & & & 0.18 & 1.04 & 2.24 \\
\hline Century Plaza 2 & & & & 0.86 & 2.05 \\
\hline North Park Plaza & & & & & 1.20 \\
\hline
\end{tabular}




\section{TRIP CALCULATION}

Average daily trips are calculated by 1) using inputs from survey data and applying weight factors to normalize the survey's population distribution with the actual population distribution; 2) determining the population of potential transit riders in the route service area; and 3) making further adjustments to account for special populations.

First, the basic calculation is made for weighted daily trips to a destination per person in each age group. The calculation takes the total weekly travel demand for each location in each age group, and then divides this total by the 7 days to get the average daily travel demand for each age group. This result is then multiplied by each age group's appropriate weighted factor to account for the disparity in population proportions between the sample and the actual population. Average daily trips are shown in Table 29.

$$
\text { Weighted Daily Trips }=\frac{T}{7} * W f
$$

Where,

Weighted Daily Trips = daily trips per person in an age group per day with an applied weight

$T=$ total weekly number of trips made to each destination per age group (Figure 9)

$R=$ number of respondents per age group (Appendix Table B1)

$W f=$ weight factor: 0.94 for ages $25-44,0.50$ for ages $45-64,0.60$ for over 64 (Table 2) 
Table 29. WEIGHTED DAILY TRIPS PER PERSON IN EACH AGE GROUP

\begin{tabular}{|l|r|r|r|r|}
\hline & \multicolumn{1}{|c|}{$25-44$} & \multicolumn{1}{c|}{$45-64$} & \multicolumn{1}{c|}{ Over 64} & \multicolumn{1}{c|}{ Sum } \\
\hline Atlantic Plaza Shopping Center & \multicolumn{1}{|c|}{0.17} & \multicolumn{1}{|c|}{0.04} & 0.03 & 0.24 \\
\hline Century Plaza Shopping Center & 0.13 & 0.04 & 0.04 & 0.21 \\
\hline Civic Center (City Hall, Court House, Library) & 0.22 & 0.09 & 0.02 & 0.33 \\
\hline Hampton Inn (California Ave and Carion Ct) & 0.04 & 0.00 & 0.00 & 0.04 \\
\hline North Park Plaza (WinCo Foods) & 0.15 & 0.04 & 0.04 & 0.23 \\
\hline Old Town & 0.21 & 0.08 & 0.07 & 0.36 \\
\hline Pittsburg Marina & 0.08 & 0.04 & 0.04 & 0.16 \\
\hline Pittsburg/ Bay Point BART & 0.22 & 0.08 & 0.02 & 0.32 \\
\hline Senior Center (Presidio Ln) & 0.07 & 0.00 & 0.03 & 0.10 \\
\hline School (Pittsburg High, Marina Vista) & 0.03 & 0.03 & 0.01 & 0.07 \\
\hline Sum & 1.31 & 0.44 & 0.31 & 2.07 \\
\hline
\end{tabular}

Second, weighted daily trips are applied to the population of potential transit users. Weighted daily trips for each age group - population pair (represented in each cell of Table 29) are multiplied by the total population of that age group along the proposed transit route. Table 30 shows the resulting number of daily trips produced by the population along the transit route. Detailed spreadsheets of calculations are found in Appendix A, section AE. 
Table 30. ALTERNATIVE 2: WEIGHTED DAILY TRIPS OF POPULATION NEAR SHUTTLE ROUTE

\begin{tabular}{|l|r|r|r|r|}
\hline & $25-44$ & $45-64$ & Over 64 & \multicolumn{1}{c|}{ Sum } \\
\hline Atlantic Plaza Shopping Center & 9 & 2 & 0 & 12 \\
\hline Century Plaza Shopping Center & 13 & 3 & 1 & 17 \\
\hline Civic Center (City Hall, Court House, Library) & 19 & 6 & 0 & 26 \\
\hline Hampton Inn (California Ave and Carion Ct) & 4 & 0 & 0 & 4 \\
\hline North Park Plaza (WinCo Foods) & 15 & 4 & 1 & 20 \\
\hline Old Town & 17 & 6 & 2 & 25 \\
\hline Pittsburg Marina & 7 & 3 & 1 & 11 \\
\hline Pittsburg/ Bay Point BART & 22 & 6 & 1 & 29 \\
\hline Senior Center (Presidio Ln) & 4 & 0 & 0 & 4 \\
\hline School (Pittsburg High, Marina Vista) & 3 & 2 & 0 & 5 \\
\hline Sum & 112 & 32 & 8 & 152 \\
\hline
\end{tabular}

$$
T=H B S h o p(L * W)
$$

Where,

$T=$ potential transit trips to a destination

HBShop $=$ Home-based-shopping trip made by transit (4 percent of trips)*

$L=$ population of people in an age group living within $1 / 4$ mile of a shuttle route that would make trips (Appendix Table A17)

$W=$ weighted daily trips by age group (Table 24)

*Source: Contra Costa Transportation Authority (2003)

The variable $T$, from the equation above, is the potential number of one-way trips to a destination; it is applied in each cell of Table 30. The weighted daily trips $(W)$ in Table 29 are multiplied by two factors. One factor in the equation is HBShop, the proportion of trips made by transit for the purposes of shopping 
and commercial activities (CCTA, 2003). Another factor is the population living within $1 / 4$ mile of a shuttle route that would make trips (the variable $L$ ), which refers to the people who would likely require some form of transportation to make a trip. In other words, the population of potential shuttle users is equal to the number of residents around a transit route excluding those who live in units where the origin and destination of a trip would be in the same area. For example, the population of trip makers that want to travel to the Atlantic Plaza Shopping Center area will contain all housing units within $1 / 4$ mile of the route minus all housing units immediately around the Atlantic Plaza Shopping area. This population is expressed as the following function.

$$
L=P *[H *(U-A)]
$$

Where,

$L=$ population of people in an age group living within $1 / 4$ mile of a shuttle route that would make trips (Appendix Table A17)

$P=$ proportion of population in age group( 0.29 for $25-44 ; 0.24$ for $45-63 ; 0.09$ for Over 64) (Census, 2010)

$H=$ average household size in Pittsburg (3.22)(Census, 2010)

$U=$ total housing units within $1 / 4$ mile of shuttle routes (2240) (Appendix Table A16)

$A=$ total number of units in area of trip origin (Appendix Table A16)

Third, the total trips require more adjustments to account for various factors. Senior housing units are not included in the previous calculations because multiplying each senior housing unit by 3.22 , the average household size, would likely overestimate trips for these smaller living units. Instead, the number of daily trips from a senior housing unit to a destination (shown in Table 29) is multiplied by the number of senior units (with the assumption that each unit is occupied by one 
person who would make a trip), then by 0.04 (the proportion of trips made by transit). The additional daily trips for each destination are rounded then added to the sum trips calculated in Table 30.

Some omissions were made due to the uncertainty of present conditions or survey responses. The ridership interested in the BART connection is also omitted for now due to the unknown status of the eBART station on Railroad Avenue. The age group under 24 years old is omitted from the analysis due to the few responses received and the concern about overestimation or underestimation of needs. Other destinations excluded in the final trip consideration are the senior center and schools. These locations are difficult to estimate based on the few responses from the survey. Furthermore, these locations are close to other locations that are represented: the senior center is near Atlantic Plaza Shopping Center and the schools are near Old Town. These nearby locations could serve as proxies to trips that would be made to the senior center and schools. Removing trips from the final ridership calculation is done to limit the effects of less reliable data. This analysis takes a more conservative approach in estimating ridership. After all adjustments, the number of passengers per day is 117 (or 234 trips). Figure 15 shows the daily trip distribution once all factors have been included, and Table 31 shows the break down. 


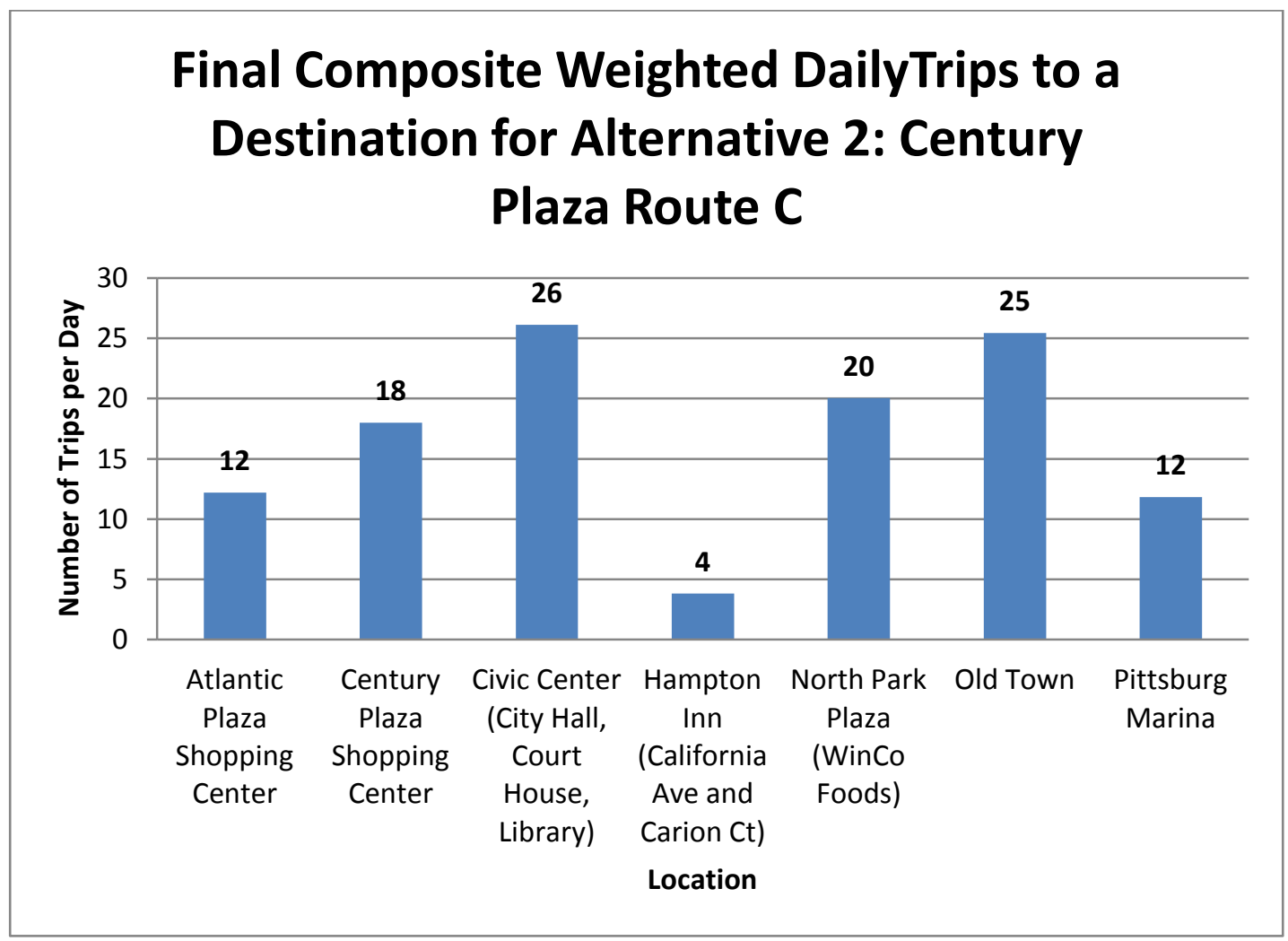

Table 31. ALTERNATIVE 2: FINAL COMPOSITE WEIGHTED DAILY TRIPS TO A DESTINATION

\begin{tabular}{|l|r|r|r|r|}
\hline & \multicolumn{1}{|c|}{$25-44$} & \multicolumn{1}{l|}{ S5-64 } & \multicolumn{1}{l|}{ Over 64} & \multicolumn{1}{l|}{ Sum } \\
\hline Atlantic Plaza Shopping Center & 9 & 2 & 1 & 12 \\
\hline Century Plaza Shopping Center & 13 & 3 & 2 & 18 \\
\hline Civic Center (City Hall, Court House, Library) & 19 & 6 & 1 & 26 \\
\hline Hampton Inn (California Ave and Carion Ct) & 4 & 0 & 0 & 4 \\
\hline North Park Plaza (WinCo Foods) & 15 & 4 & 2 & 20 \\
\hline Old Town & 17 & 6 & 3 & 25 \\
\hline Pittsburg Marina & 7 & 3 & 2 & 12 \\
\hline Pittsburg/ Bay Point BART & 0 & 0 & & 0 \\
\hline Senior Center (Presidio Ln) & 0 & 0 & & 0 \\
\hline School (Pittsburg High, Marina Vista) & 0 & 0 & & 0 \\
\hline Sum & 84 & 24 & 9 & 117 \\
\hline
\end{tabular}


Approximately 234 passenger trips are projected per day (assuming roundtrips for each of the 117 trips to a destination). Since 12 revenue service hours is considered "all day" service and 2 vehicles operate all day, passengers per hour can be calculated as 234 passengers per day divided by 24 hours ( 2 vehicles operating at 12 hours each). The resulting rate of 10 passengers per hour(pph) provides an hourly performance measure. More importantly, the rate provides a more appropriate means to calculate ridership over shorter operating periods. For example, "Weekday AM and PM Peak Only" service only operates each of the two routes for 6 hours per day and it may not be reasonable to expect 234 passengers (or 20 pph on each route) in those limited hours. Applying the hourly rate of $10 \mathrm{pph}$ for each route creates a projection of 120 total passengers per day, which is a more likely estimate than one that assumes all 234 potential daily riders would schedule their trips around very limited service hours. Overall, the range of ridership may be somewhere around 10 passengers per hour. It is in the lower range of the expected 10 to 17 passengers per hour for average shuttles, but the groups omitted in the study would likely bring the passenger boarding rates further into the average range. 


\section{COST ANALYSIS}

Table 32 shows the additional required costs for shuttle operation after factoring in potential business contributions and fare revenues. The table adjusts the base costs presented in Table 7 of Evaluation of Costs to reflect the cost of service assuming some funding contributions and revenue recovery. These calculations assume a $\$ 25$ per month business contribution from 20 businesses each year, which totals $\$ 6,000$. Passenger fare revenues were calculated by multiplying the average number of passengers per day by the number of days per year, or the number of passengers per hour by the number of hours per year. The cost recovery is based on basic willingness-to=pay assumptions derived from the survey rather than alternative financing mechanisms.

At a one-dollar fare, some cost expenditures can be recovered but not enough to substantially offset the cost of operation. The "Weekday All Day" and the "Weekday All Day with 30 Minute Peak Headways" options, which consist of two routes that each operate 5 days per week for 50 weeks, the routes each return about $\$ 59,000$ per year from the 234 passengers per day. The "Weekday AM and PM Peak Only" option returns about $\$ 29,000$ per year from 10 passengers per hour times 6 hours per day for 250 weekdays times two routes. The "Weekday AM and PM Peak, Plus Weekend All Day" option, which consists of two routes that each operate on 6 peak hours every weekday and 2 days over the weekend for 50 weeks, returns about $\$ 53,000$ per year. Revenue recovery and business contributions for service do not substantially decrease annual operating costs, so 
providing the shuttles without fares may be an appropriate choice if providing benefits to the community are more important than minor cost recovery.

Table 32. ALTERNATIVE 2: ANNUAL SHUTTLE COSTS MINUS BUSINESS CONTRIBUTION AND FARES

\begin{tabular}{|c|c|c|c|c|c|}
\hline & Fare: Free & $\$ 0.25$ & $\$ 0.50$ & $\$ 1$ \\
\hline \multirow{4}{*}{$\begin{array}{l}\text { Operating } \\
\text { Cost of } \\
\$ 60 \text { per } \\
\text { Hour }\end{array}$} & $\begin{array}{l}\text { Weekday AM and } \\
\text { PM Peak Only }\end{array}$ & $(\$ 174,000)$ & $(\$ 166,659)$ & $(\$ 159,318)$ & $(\$ 144,637)$ \\
\hline & $\begin{array}{l}\text { Weekday AM and } \\
\text { PM Peak, Plus } \\
\text { Weekend All Day }\end{array}$ & $(\$ 294,000)$ & $(\$ 280,787)$ & $(\$ 267,573)$ & $(\$ 241,146)$ \\
\hline & Weekday All Day & $(\$ 354,000)$ & $(\$ 339,318)$ & $(\$ 324,637)$ & $(\$ 295,274)$ \\
\hline & $\begin{array}{l}\text { Weekday All Day } \\
\text { with } 30 \text { Minute Peak } \\
\text { Headways }\end{array}$ & $(\$ 474,000)$ & $(\$ 459,318)$ & $(\$ 444,637)$ & $(\$ 415,274)$ \\
\hline \multirow{4}{*}{$\begin{array}{l}\text { Operating } \\
\text { Cost of } \\
\$ 70 \text { per } \\
\text { Hour }\end{array}$} & $\begin{array}{l}\text { Weekday AM and } \\
\text { PM Peak Only }\end{array}$ & $(\$ 204,000)$ & $(\$ 196,659)$ & $(\$ 189,318)$ & $(\$ 174,637)$ \\
\hline & $\begin{array}{l}\text { Weekday AM and } \\
\text { PM Peak, Plus } \\
\text { Weekend All Day }\end{array}$ & $(\$ 344,000)$ & $(\$ 330,787)$ & $(\$ 317,573)$ & $(\$ 291,146)$ \\
\hline & Weekday All Day & $(\$ 414,000)$ & $(\$ 399,318)$ & $(\$ 384,637)$ & $(\$ 355,274)$ \\
\hline & $\begin{array}{l}\text { Weekday All Day } \\
\text { with } 30 \text { Minute Peak } \\
\text { Headways }\end{array}$ & $(\$ 554,000)$ & $(\$ 539,318)$ & $(\$ 524,637)$ & $(\$ 495,274)$ \\
\hline \multirow{4}{*}{$\begin{array}{l}\text { Operating } \\
\text { Cost of } \\
\$ 80 \text { per } \\
\text { Hour }\end{array}$} & $\begin{array}{l}\text { Weekday AM and } \\
\text { PM Peak Only }\end{array}$ & $(\$ 234,000)$ & $(\$ 226,659)$ & $(\$ 219,318)$ & $(\$ 204,637)$ \\
\hline & $\begin{array}{l}\text { Weekday AM and } \\
\text { PM Peak, Plus } \\
\text { Weekend All Day }\end{array}$ & $(\$ 394,000)$ & $(\$ 380,787)$ & $(\$ 367,573)$ & $(\$ 341,146)$ \\
\hline & Weekday All Day & $(\$ 474,000)$ & $(\$ 459,318)$ & $(\$ 444,637)$ & $(\$ 415,274)$ \\
\hline & $\begin{array}{l}\text { Weekday All Day } \\
\text { with } 30 \text { Minute Peak } \\
\text { Headways }\end{array}$ & $(\$ 634,000)$ & $(\$ 619,318)$ & $(\$ 604,637)$ & $(\$ 575,274)$ \\
\hline
\end{tabular}




\section{VID. ALTERNATIVE PLAN 3: CENTURY PLAZA ROUTE L}

This plan is a modification of Alternative 2 that reconfigures the Century Plaza route to serve residents along East Leland Road. It incorporates all elements of Alternative 1, creating a north-south Railroad Avenue route between Old Town and Atlantic Plaza, and adds an east-west route along stretches of East Leland Road before taking passengers to North Park Plaza and finally Century Plaza (Figure 16). This configuration provides service to the largest number of potential passengers among all of the alternatives, covering an area of about 3400 housing units. New stops, including one placed near Wal-Mart and one at Los Medanos College, increase the variety of attractions along the shuttle route and serve multiple uses (Table 33). A transfer point at the Civic Center between the Railroad Avenue route and Century Plaza Route $L$ would link the attractions of Old Town and the general shopping opportunities of Atlantic Plaza with the larger scale big-box and entertainment options of North Park Plaza and Century Plaza.

One downside of this route is the overlap between the east-west Century Plaza route and Tri Delta bus lines along East Leland Road. Coordination with Tri Delta would be required to ensure that overlapping areas would not be detrimental to transit operations in the city. Even if Century Plaza Route $L$ is not implemented, coordination with Tri delta can still be made to connect east-west transit service with a Railroad Avenue shuttle route. This east-west Century Plaza configuration encourages, and most likely requires, cooperation among transit service providers in the city, to provide high quality transit service. 
Figure 16. ALTERNATIVE 3 - CENTURY PLAZA ROUTE L: ROUTES AND STOPS

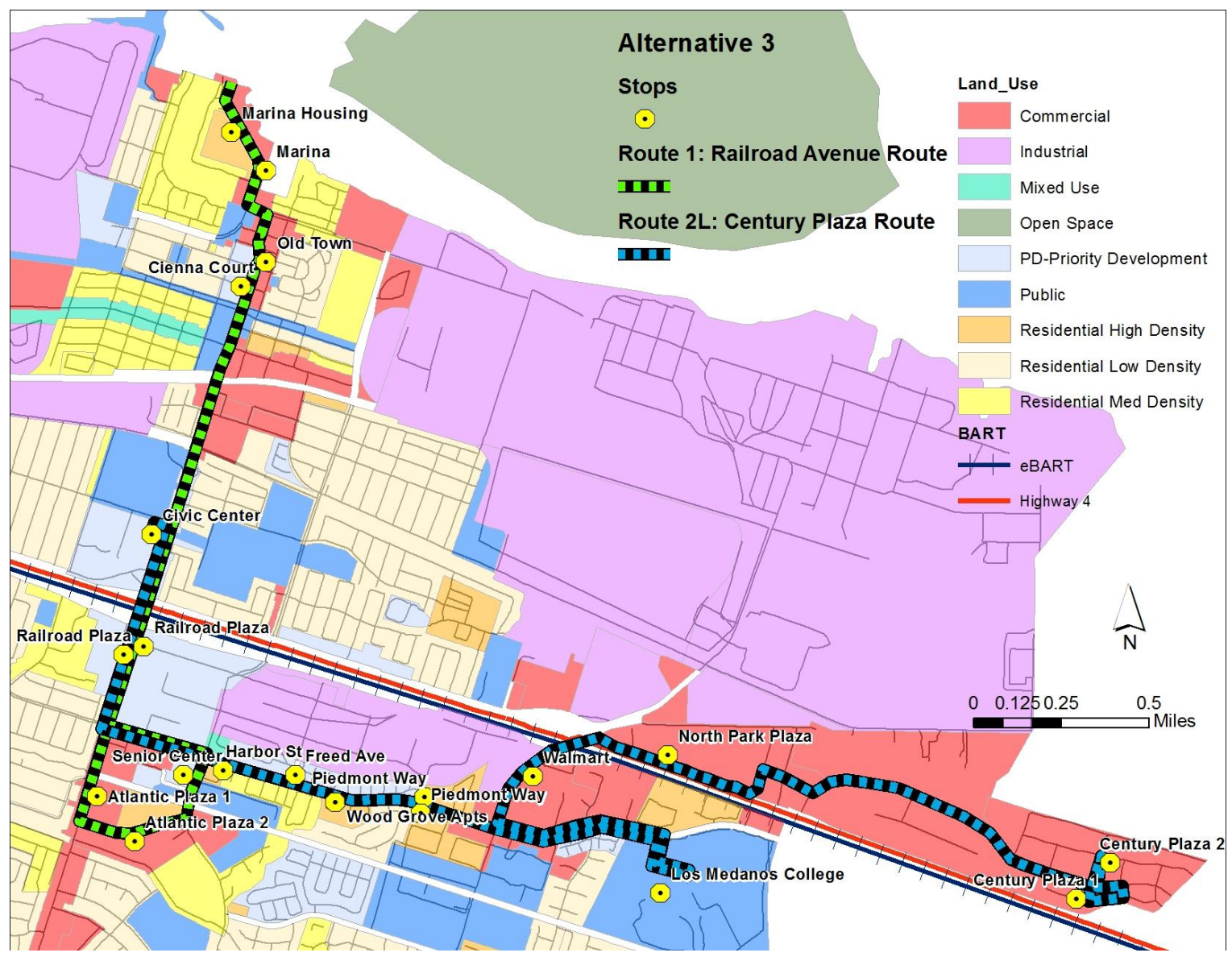

Table 33. CENTURY PLAZA ROUTE L: MILES BETWEEN STOPS

\begin{tabular}{|c|c|c|c|c|c|c|c|c|c|c|c|c|c|c|}
\hline & $\begin{array}{l}\text { Rail- } \\
\text { road } \\
\text { Plaza }\end{array}$ & $\begin{array}{l}\text { Harbor } \\
\text { St }\end{array}$ & $\begin{array}{l}\text { Wood } \\
\text { Grove } \\
\text { Apts }\end{array}$ & $\begin{array}{l}\text { Pied- } \\
\text { mont } \\
\text { Way }\end{array}$ & $\begin{array}{l}\text { Wal- } \\
\text { mart }\end{array}$ & $\begin{array}{l}\text { North } \\
\text { Park } \\
\text { Plaza }\end{array}$ & $\begin{array}{l}\text { Century } \\
\text { Plaza } 1\end{array}$ & $\begin{array}{l}\text { Century } \\
\text { Plaza 2 }\end{array}$ & $\begin{array}{l}\text { North } \\
\text { Park } \\
\text { Plaza }\end{array}$ & $\begin{array}{l}\text { Los Med- } \\
\text { anos }\end{array}$ & $\begin{array}{l}\text { Pied- } \\
\text { mont } \\
\text { Way }\end{array}$ & \begin{tabular}{|l|} 
Freed \\
Ave
\end{tabular} & $\begin{array}{l}\text { Rail- } \\
\text { road } \\
\text { Ave }\end{array}$ & $\begin{array}{l}\text { Civic } \\
\text { Center }\end{array}$ \\
\hline Civic Center & 0.5 & 1.0 & 1.4 & 1.6 & 2.0 & 2.4 & 3.9 & 4.2 & 5.6 & 6.9 & 7.8 & 8.2 & 9.0 & 9.4 \\
\hline Railroad Plaza & & 0.5 & 0.9 & 1.1 & 1.6 & 2.0 & 3.4 & 3.7 & 5.2 & 6.4 & 7.3 & 7.7 & 8.5 & 8.9 \\
\hline Harbor St & & & 0.3 & 0.6 & 1.0 & 1.4 & 2.9 & 3.2 & 4.6 & 5.9 & 6.8 & 7.1 & 7.9 & 8.4 \\
\hline Wood Grove Apts & & & & 0.2 & 0.7 & 1.1 & 2.5 & 2.8 & 4.3 & 5.5 & 6.4 & 6.8 & 7.6 & 8.0 \\
\hline Piedmont Way & & & & & 0.4 & 0.8 & 2.3 & 2.6 & 4.0 & 5.3 & 6.2 & 6.6 & 7.3 & 7.8 \\
\hline Walmart & & & & & & 0.4 & 1.9 & 2.2 & 3.6 & 4.9 & 5.8 & 6.1 & 6.9 & 7.4 \\
\hline NorthPark Plaza & & & & & & & 1.4 & 1.7 & 3.2 & 4.5 & 5.3 & 5.7 & 6.5 & 7.0 \\
\hline Century Plaza 1 & & & & & & & & 0.3 & 1.7 & 3.0 & 3.9 & 4.3 & 5.1 & 5.5 \\
\hline Century Plaza 2 & & & & & & & & & 1.4 & 2.7 & 3.6 & 4.0 & 4.8 & 5.2 \\
\hline NorthPark Plaza & & & & & & & & & & 1.3 & 2.2 & 2.5 & 3.3 & 3.8 \\
\hline Los Medanos & & & & & & & & & & & 0.9 & 1.3 & 2.0 & 2.5 \\
\hline Piedmont Way & & & & & & & & & & & & 0.4 & 1.2 & 1.6 \\
\hline Freed Ave & & & & & & & & & & & & & 0.8 & 1.2 \\
\hline Railroad Ave & & & & & & & & & & & & & & 0.4 \\
\hline
\end{tabular}




\section{ROUTE PLANNING}

This two-route configuration maximizes the service coverage to the largest potential population. Residents living near the Pittsburg Marina and connected with residents living around the Atlantic Plaza area via the north-south Railroad Avenue route. The unique feature of this alternative is the east-west route configuration on East Leland Road. The longer length of this route also increases travel time between the Civic Center and Century Plaza. This alternative provides the greatest coverage, has the largest potential ridership, and provides access to other major destinations in the eastern half of the city.

This section primarily covers the alternative Century Plaza route in terms of route planning characteristics because the Railroad Avenue route is unchanged from the proposal described in Alternative 1.The Railroad Avenue route is 2.6 miles in one direction (5.2 miles for a full cycle) connecting the Pittsburg Marina with Atlantic Plaza Shopping Center. Shuttles traveling at 14 miles per hour are capable of meeting headways of 30 minutes with one vehicle.

The Century Plaza route is a 4.7-mile stretch. Table 33 shows the distance between stops along the full 9.4-mile cycle of a complete route. To cover this 9.4-mile stretch, several assumptions are made to match required vehicle speeds with desired travel time. Table 34 shows the expected in-vehicle travel time to provide a sense of time in transit from the passenger's perspective. It also reflects a planned stop-to-stop travel time standard that will need to be maintained in order 
to meet one-hour headways. One shuttle can provide transit service on 60 -minute headways but two shuttles will be required for half-hour headways during peak hours. The shuttle's ability to meet this target assumes that an average speed of 13 miles per hour will be maintained. Details are included in Appendix Table A1.

One-hour headways can be met with one vehicle along the Century Plaza route. The total in-vehicle travel time, calculated as the sum of travel times for each route segment, for the Century Plaza route is 42.4 minutes (Table 34). Each cell in the table is populated by the function below.

$$
T_{s}=\frac{v_{\max }}{2}\left(\frac{1}{a}+\frac{1}{b}\right)+\frac{S}{v_{\max }}
$$

Where,

$T_{S}$ is travel time between stations

$S$ [ft] is spacing greater than $S_{c}$

$v_{\max }$ is the maximum speed

$a$ [ft./sec $\left.{ }^{\wedge} 2\right]$ is acceleration rate

$b$ [ft./sec $\left.{ }^{\wedge} 2\right]$ is deceleration rate

The calculations for station-to-station travel time are shown in detail in Appendix $A$, section $A B$. An alternative method of calculation that estimates travel time for the route as a whole returns roughly the same results, with a 43.4-minute travel time for one cycle (Appendix Table A1). When factoring in a minimum terminal time (15 percent of total travel time), the subtotal for minimum travel time becomes 49.9 minutes. Adding a 15-second passenger loading and unloading period for each stop, the shuttle is still able to meet the half hour headway. The total travel time for one cycle is $\mathbf{5 3 . 4}$ minutes. 
Several assumptions are made in the calculation of station-to-station travel time. Equations estimating station-to-station travel time used in the calculation of Table 34 can be found in Appendix Table A5. Equations are determined as a function of speed, acceleration, and distance. The spacing between stops is sufficient for vehicles to meet the desired speeds of $13 \mathrm{mph}$. Future vehicle on-road performances should be conducted to confirm this assumption.

Table 34. CENTURY PLAZA ROUTE L: TRANSIT IN VEHICLE TRAVEL TIME (IN MINUTES)

\begin{tabular}{|c|c|c|c|c|c|c|c|c|c|c|c|c|c|c|}
\hline & $\begin{array}{l}\text { Rail- } \\
\text { road } \\
\text { Plaza }\end{array}$ & $\begin{array}{l}\text { Harbor } \\
\text { St }\end{array}$ & $\begin{array}{l}\text { Wood } \\
\text { Grove } \\
\text { Apts } \\
\end{array}$ & $\begin{array}{l}\text { Pied- } \\
\text { mont } \\
\text { Way }\end{array}$ & $\begin{array}{l}\text { Wal- } \\
\text { mart }\end{array}$ & $\begin{array}{l}\text { North } \\
\text { Park } \\
\text { Plaza }\end{array}$ & $\begin{array}{l}\text { Century } \\
\text { Plaza } 1\end{array}$ & $\begin{array}{l}\text { Century } \\
\text { Plaza } 2 \\
\end{array}$ & $\begin{array}{l}\text { North } \\
\text { Park } \\
\text { Plaza }\end{array}$ & $\begin{array}{l}\text { Los } \\
\text { Med- } \\
\text { anos }\end{array}$ & $\begin{array}{l}\text { Pied- } \\
\text { mont } \\
\text { Way }\end{array}$ & \begin{tabular}{|l} 
Freed \\
Ave
\end{tabular} & $\begin{array}{l}\text { Rail- } \\
\text { road } \\
\text { Ave }\end{array}$ & $\begin{array}{l}\text { Civic } \\
\text { Center }\end{array}$ \\
\hline Civic Center & 2.1 & 4.6 & 6.1 & 7.2 & 9.0 & 10.9 & 17.5 & 18.8 & 25.4 & 31.3 & 35.2 & 36.9 & 40.5 & 42.4 \\
\hline Railroad Plaza & & 2.5 & 4.0 & 5.0 & 6.9 & 8.8 & 15.3 & 16.7 & 23.3 & 29.1 & 33.1 & 34.8 & 38.4 & 40.3 \\
\hline Harbor St & & & 1.5 & 2.6 & 4.4 & 6.3 & 12.9 & 14.2 & 20.8 & 26.7 & 30.6 & 32.3 & 35.9 & 37.9 \\
\hline Wood Grove Apts & & & & 1.1 & 2.9 & 4.8 & 11.4 & 12.7 & 19.3 & 25.2 & 29.1 & 30.8 & 34.4 & 36.3 \\
\hline Piedmont Way & & & & & 1.9 & 3.7 & 10.3 & 11.6 & 18.2 & 24.1 & 28.0 & 29.7 & 33.3 & 35.3 \\
\hline Walmart & & & & & & 1.9 & 8.4 & 9.8 & 16.3 & 22.2 & 26.2 & 27.9 & 31.5 & 33.4 \\
\hline NorthPark Plaza & & & & & & & 6.6 & 7.9 & 14.5 & 20.4 & 24.3 & 26.0 & 29.6 & 31.6 \\
\hline Century Plaza 1 & & & & & & & & 1.3 & 7.9 & 13.8 & 17.7 & 19.4 & 23.0 & 25.0 \\
\hline Century Plaza 2 & & & & & & & & & 6.6 & 12.5 & 16.4 & 18.1 & 21.7 & 23.6 \\
\hline NorthPark Plaza & & & & & & & & & & 5.9 & 9.8 & 11.5 & 15.1 & 17.1 \\
\hline Los Medanos & & & & & & & & & & & 4.0 & 5.6 & 9.2 & 11.2 \\
\hline Piedmont Way & & & & & & & & & & & & 1.7 & 5.3 & 7.2 \\
\hline Freed Ave & & & & & & & & & & & & & 3.6 & 5.6 \\
\hline Railroad Ave & & & & & & & & & & & & & & 1.9 \\
\hline
\end{tabular}

In-vehicle travel time in a shuttle can be compared to the time it takes to drive between the same stop locations. Table 35 shows the difference between transit travel time and automobile travel time under the assumption that drivers on Railroad Avenue would travel at an average speed of 25 miles per hour. The difference becomes noticeable for longer trips. A trip between "Civic Center" and "Century Plaza 1," the two ends of the route, is about 8 minutes longer by shuttle. 
Table 35. CENTURY PLAZA ROUTE L: DIFFERENCE IN TRAVEL TIME BETWEEN AUTOMOBILE AND TRANSIT (IN MINUTES)

\begin{tabular}{|c|c|c|c|c|c|c|c|c|c|c|c|c|c|c|}
\hline & $\begin{array}{l}\text { Rail- } \\
\text { road } \\
\text { Plaza }\end{array}$ & $\begin{array}{l}\text { Harbor } \\
\text { St }\end{array}$ & $\begin{array}{l}\text { Wood } \\
\text { Grove } \\
\text { Apts }\end{array}$ & $\begin{array}{l}\text { Pied- } \\
\text { mont } \\
\text { Way }\end{array}$ & $\begin{array}{l}\text { Wal- } \\
\text { mart }\end{array}$ & $\begin{array}{l}\text { North } \\
\text { Park } \\
\text { Plaza }\end{array}$ & $\begin{array}{l}\text { Century } \\
\text { Plaza } 1\end{array}$ & $\begin{array}{l}\text { Century } \\
\text { Plaza } 2\end{array}$ & $\begin{array}{l}\text { North } \\
\text { Park } \\
\text { Plaza }\end{array}$ & $\begin{array}{l}\text { Los } \\
\text { Med- } \\
\text { anos }\end{array}$ & $\begin{array}{l}\text { Pied- } \\
\text { mont } \\
\text { Way }\end{array}$ & \begin{tabular}{|l|} 
Freed \\
Ave
\end{tabular} & $\begin{array}{l}\text { Rail- } \\
\text { road } \\
\text { Ave }\end{array}$ & $\begin{array}{l}\text { Civic } \\
\text { Center }\end{array}$ \\
\hline Civic Center & 1.0 & 2.1 & 2.8 & 3.3 & 4.2 & 5.0 & 8.1 & 8.8 & 11.9 & 14.7 & 16.5 & 17.3 & 19.0 & 19.9 \\
\hline Railroad Plaza & & 1.2 & 1.8 & 2.3 & 3.2 & 4.0 & 7.2 & 7.8 & 10.9 & 13.7 & 15.5 & 16.3 & 18.0 & 18.9 \\
\hline Harbor St & & & 0.7 & 1.2 & 2.0 & 2.9 & 6.0 & 6.6 & 9.7 & 12.5 & 14.4 & 15.2 & 16.9 & 17.8 \\
\hline Wood Grove Apts & & & & 0.5 & 1.3 & 2.2 & 5.3 & 5.9 & 9.0 & 11.8 & 13.7 & 14.5 & 16.2 & 17.1 \\
\hline Piedmont Way & & & & & 0.9 & 1.7 & 4.8 & 5.4 & 8.6 & 11.4 & 13.2 & 14.0 & 15.7 & 16.6 \\
\hline Walmart & & & & & & 0.9 & 4.0 & 4.6 & 7.7 & 10.5 & 12.4 & 13.1 & 14.8 & 15.7 \\
\hline NorthPark Plaza & & & & & & & 3.1 & 3.7 & 6.9 & 9.6 & 11.5 & 12.3 & 14.0 & 14.9 \\
\hline Century Plaza 1 & & & & & & & & 0.6 & 3.7 & 6.5 & 8.4 & 9.2 & 10.9 & 11.8 \\
\hline Century Plaza 2 & & & & & & & & & 3.1 & 5.9 & 7.8 & 8.6 & 10.2 & 11.1 \\
\hline NorthPark Plaza & & & & & & & & & & 2.8 & 4.7 & 5.4 & 7.1 & 8.0 \\
\hline \begin{tabular}{|l|} 
Los Medanos \\
\end{tabular} & & & & & & & & & & & 1.9 & 2.6 & 4.3 & 5.2 \\
\hline Piedmont Way & & & & & & & & & & & & 0.8 & 2.5 & 3.4 \\
\hline Freed Ave & & & & & & & & & & & & & 1.7 & 2.6 \\
\hline Railroad Ave & & & & & & & & & & & & & & 0.9 \\
\hline
\end{tabular}

There is a tradeoff between travel time and cost of travel. The cost of automobile travel along the Century Plaza route is higher than shuttle fare for most trips. A one dollar fare can be compared to the cost of travel between stops, shown in Table 36 . The cost of automobile travel is 59.6 cents per mile, as described by Pritchett (2012), times the number of miles between stops. A trip from "Civic Center" and "Century Plaza 1" is more than would cost a driver an extra two dollars each way. The full price of automobile travel on a trip-by-trip basis may not be perceived by most drivers, but the breakdown of travel cost difference can highlight some of the cost saving benefits from transit use. 
Table 36. CENTURY PLAZA ROUTE L: OUT-OF-POCKET COSTS FOR AUTOMOBILE TRAVEL (IN DOLLARS)

\begin{tabular}{|c|c|c|c|c|c|c|c|c|c|c|c|c|c|c|}
\hline & \begin{tabular}{|l|} 
Rail- \\
road \\
Plaza
\end{tabular} & $\begin{array}{l}\text { Harbor } \\
\text { St }\end{array}$ & $\begin{array}{l}\text { Wood } \\
\text { Grove } \\
\text { Apts }\end{array}$ & $\begin{array}{l}\text { Pied- } \\
\text { mont } \\
\text { Way }\end{array}$ & $\begin{array}{l}\text { Wal- } \\
\text { mart }\end{array}$ & $\begin{array}{l}\text { North } \\
\text { Park } \\
\text { Plaza }\end{array}$ & $\begin{array}{l}\text { Atlantic } \\
\text { Plaza 1 }\end{array}$ & $\begin{array}{l}\text { Atlantic } \\
\text { Plaza } 2\end{array}$ & \begin{tabular}{|l|} 
North \\
Park \\
Plaza \\
\end{tabular} & $\begin{array}{l}\text { Los } \\
\text { Med- } \\
\text { anos }\end{array}$ & $\begin{array}{l}\text { Pied- } \\
\text { mont } \\
\text { Way }\end{array}$ & \begin{tabular}{|l} 
Freed \\
Ave
\end{tabular} & $\begin{array}{l}\text { Rail- } \\
\text { road } \\
\text { Ave }\end{array}$ & $\begin{array}{l}\text { Civic } \\
\text { Center }\end{array}$ \\
\hline Civic Center & 0.28 & 0.61 & 0.81 & 0.96 & 1.21 & 1.46 & 2.31 & 2.49 & 3.35 & 4.12 & 4.64 & 4.87 & \begin{tabular}{|l|}
5.34 \\
\end{tabular} & 5.60 \\
\hline Railroad Plaza & & 0.33 & 0.53 & 0.68 & 0.93 & 1.17 & 2.03 & 2.21 & 3.07 & 3.84 & 4.36 & 4.58 & 5.06 & 5.32 \\
\hline Harbor St & & & 0.20 & 0.35 & 0.60 & 0.85 & 1.70 & 1.89 & 2.74 & 3.51 & 4.03 & 4.26 & 4.73 & 4.99 \\
\hline Wood Grove Apts & & & & 0.15 & 0.40 & 0.64 & 1.50 & 1.68 & 2.54 & 3.31 & 3.83 & 4.05 & 4.53 & 4.79 \\
\hline \begin{tabular}{|l} 
Piedmont Way \\
\end{tabular} & & & & & 0.25 & 0.50 & 1.35 & 1.54 & 2.39 & 3.16 & 3.68 & 3.91 & 4.38 & 4.64 \\
\hline \begin{tabular}{|l} 
Walmart \\
\end{tabular} & & & & & & 0.25 & 1.11 & 1.29 & 2.14 & 2.91 & 3.43 & 3.66 & 4.13 & 4.39 \\
\hline NorthPark Plaza & & & & & & & 0.86 & 1.04 & 1.90 & 2.66 & 3.18 & 3.41 & 3.88 & 4.14 \\
\hline Atlantic Plaza 1 & & & & & & & & 0.18 & 1.04 & 1.81 & 2.33 & 2.55 & 3.03 & 3.28 \\
\hline Atlantic Plaza 2 & & & & & & & & & 0.86 & 1.63 & 2.14 & 2.37 & 2.84 & 3.10 \\
\hline NorthPark Plaza & & & & & & & & & & 0.77 & 1.29 & 1.51 & 1.99 & 2.25 \\
\hline Los Medanos & & & & & & & & & & & 0.52 & 0.75 & 1.22 & 1.48 \\
\hline Piedmont Way & & & & & & & & & & & & 0.23 & 0.70 & 0.96 \\
\hline \begin{tabular}{|l|} 
Freed Ave \\
\end{tabular} & & & & & & & & & & & & & 0.47 & 0.73 \\
\hline Railroad Ave & & & & & & & & & & & & & & 0.26 \\
\hline
\end{tabular}

\section{TRIP CALCULATION}

Average daily trips are calculated by 1) applying inputs from survey data and applying weight factors to normalize the survey's population distribution with the actual population distribution; 2) determining the population of potential transit riders in the route service area; and 3) making further adjustments to account for special populations.

First, the basic calculation is made for weighted daily trips to a destination per person in an age group. The calculation takes the total weekly travel demand for each location in each age group, and then divides this total by seven days to get the average daily travel demand for each age group. This result is then multiplied by each age group's appropriate weighted factor to account for the disparity in population proportions between the sample and the actual population. Average daily trips are shown in Table 32. 
Weighted Daily Trips $=\frac{\frac{T}{R}}{7} * W f$

Where,

Weighted Daily Trips = daily trips per person in an age group per day with an applied weight

$T=$ total weekly number of trips made to each destination per age group (Figure 9)

$R=$ number of respondents per age group (Appendix Table B1)

$W f=$ weight factor: 0.94 for ages 25-44, 0.50 for ages 45-64, 0.60 for over 64 (Table 2)

Table 37. WEIGHTED DAILY TRIPS PER PERSON IN EACH AGE GROUP

\begin{tabular}{|l|r|r|r|r|}
\hline & \multicolumn{1}{|c|}{$25-44$} & \multicolumn{1}{c|}{$45-64$} & \multicolumn{1}{l|}{ Over 64} & \multicolumn{1}{c|}{ Sum } \\
\hline Atlantic Plaza Shopping Center & \multicolumn{1}{|c|}{0.17} & \multicolumn{1}{|c|}{0.04} & 0.03 & 0.24 \\
\hline Century Plaza Shopping Center & 0.13 & 0.04 & 0.04 & 0.21 \\
\hline Civic Center (City Hall, Court House, Library) & 0.22 & 0.09 & 0.02 & 0.33 \\
\hline Hampton Inn (California Ave and Carion Ct) & 0.04 & 0.00 & 0.00 & 0.04 \\
\hline North Park Plaza (WinCo Foods) & 0.15 & 0.04 & 0.04 & 0.23 \\
\hline Old Town & 0.21 & 0.08 & 0.07 & 0.36 \\
\hline Pittsburg Marina & 0.08 & 0.04 & 0.04 & 0.16 \\
\hline Pittsburg/ Bay Point BART & 0.22 & 0.08 & 0.02 & 0.32 \\
\hline Senior Center (Presidio Ln) & 0.07 & 0.00 & 0.03 & 0.10 \\
\hline School (Pittsburg High, Marina Vista) & 0.03 & 0.03 & 0.01 & 0.07 \\
\hline Sum & 1.31 & 0.44 & 0.31 & 2.07 \\
\hline
\end{tabular}


Second, weighted daily trips are applied to the population of potential transit users. Weighted daily trips for each age group - population pair (represented in each cell of Table 37) are multiplied by the total population of that age group along the proposed transit route. Table 38 shows the resulting number of daily trips produced by the population along the transit route. Detailed spreadsheets of calculations are found in Appendix A, section AF.

Table 38. ALTERNATIVE 3: WEIGHTED DAILY TRIPS OF POPULATION NEAR SHUTTLE ROUTE

\begin{tabular}{|l|r|r|r|r|}
\hline & $25-44$ & $45-64$ & Over 64 & \multicolumn{1}{l|}{ Sum } \\
\hline Atlantic Plaza Shopping Center & 14 & 3 & 1 & 18 \\
\hline Century Plaza Shopping Center & 17 & 4 & 2 & 23 \\
\hline Civic Center (City Hall, Court House, Library) & 26 & 9 & 1 & 35 \\
\hline Hampton Inn (California Ave and Carion Ct) & 5 & 0 & 0 & 5 \\
\hline North Park Plaza (WinCo Foods) & 19 & 5 & 1 & 25 \\
\hline Old Town & 23 & 8 & 2 & 33 \\
\hline Pittsburg Marina & 9 & 4 & 2 & 15 \\
\hline Pittsburg/ Bay Point BART & 29 & 8 & 1 & 38 \\
\hline Senior Center (Presidio Ln) & 6 & 0 & 1 & 6 \\
\hline School (Pittsburg High, Marina Vista) & 4 & 2 & 0 & 7 \\
\hline Sum & 152 & 44 & 10 & 206 \\
\hline
\end{tabular}

$$
T=H B S h o p(L * W)
$$

Where, $T=$ potential transit trips to a destination

HBShop $=$ Home-based-shopping trip made by transit (4 percent of trips)*

$L=$ population of people in an age group living within $1 / 4$ mile of a shuttle route that would make trips (Appendix Table A23)

$W=$ weighted daily trips by age group (Table 32 )

*Source: Contra Costa Transportation Authority (2003) 
The variable $T$, from the equation above, is the potential number of one-way trips to a destination; it is applied in each cell of Table 38 and is a product of $W, H B S h o p$, and $L$. The weighted daily trips $(W)$ in Table 37 are multiplied by two factors. One factor in the equation is $H B S h o p$, the proportion of trips made by transit for the purposes of shopping and commercial activities (CCTA, 2003). Another factor is the population living within $1 / 4$ mile of a shuttle route that would make trips (the variable $L$ ), which refers to the people who would likely require some form of transportation to make a trip. In other words, the population of potential shuttle users is equal to the number of residents around a transit route excluding those who live in units where the origin and destination of a trip would be in the same area. For example, the population of trip makers that want to travel to the Atlantic Plaza Shopping Center area will contain all housing units within $1 / 4$ mile of the route minus all housing units immediately around the Atlantic Plaza Shopping area. This population is expressed as the following function.

$$
L=P *[H *(U-A)]
$$

Where,

$L=$ population of people in an age group living within $1 / 4$ mile of a shuttle route that would make trips (Appendix Table A23)

$P=$ proportion of population in age group(0.29 for $25-44 ; 0.24$ for $45-63 ; 0.09$ for Over 64) (Census, 2010)

$H=$ average household size in Pittsburg (3.22)(Census, 2010)

$U=$ total housing units within $1 / 4$ mile of shuttle routes (2240) (Appendix Table A22)

$A=$ total number of units in area of trip origin (Appendix Table A22) 
Third, the total trips require more adjustments to account for various factors. Senior housing units are not included in the previous calculations because multiplying each senior housing unit by 3.22 , the average household size, would likely overestimate trips for these smaller living units. Instead, the number of daily trips from a senior housing unit to a destination (shown in Table 37) is multiplied by the number of senior units (with the assumption that each unit is occupied by one person who would make a trip), then by 0.04 (the proportion of trips made by transit). The additional daily trips for each destination are rounded then added to the sum trips calculated in Table 38.

Some omissions were made due to the uncertainty of present conditions or survey responses. The ridership interested in the BART connection has also been omitted for now due to the unknown status of the eBART station on Railroad Avenue. The age group under 24 years old has also been omitted from the analysis due to the few responses received and the concern about overestimation or underestimation of needs. Other destinations excluded in the final trip consideration are the senior center and schools. These locations are difficult to estimate based on the few responses from the survey. Furthermore, these locations are close to other locations that are represented: the senior center is near Atlantic Plaza Shopping Center and the schools are near Old Town. These nearby locations could serve as proxies to trips that would be made to the senior center and schools. Removing trips from the final ridership calculation is done to limit the effects of less reliable data. This analysis takes a more conservative 
approach in estimating ridership. After all adjustments, the number of passengers per day is 158 (or 316 trips). Figure 17 shows the daily trip distribution once all factors have been included, and Table 39 shows the break down.

Figure 17. ALTERNATIVE 3: FINAL COMPOSITE OF WEIGHTED DAILY TRIPS TO A DESTINATION

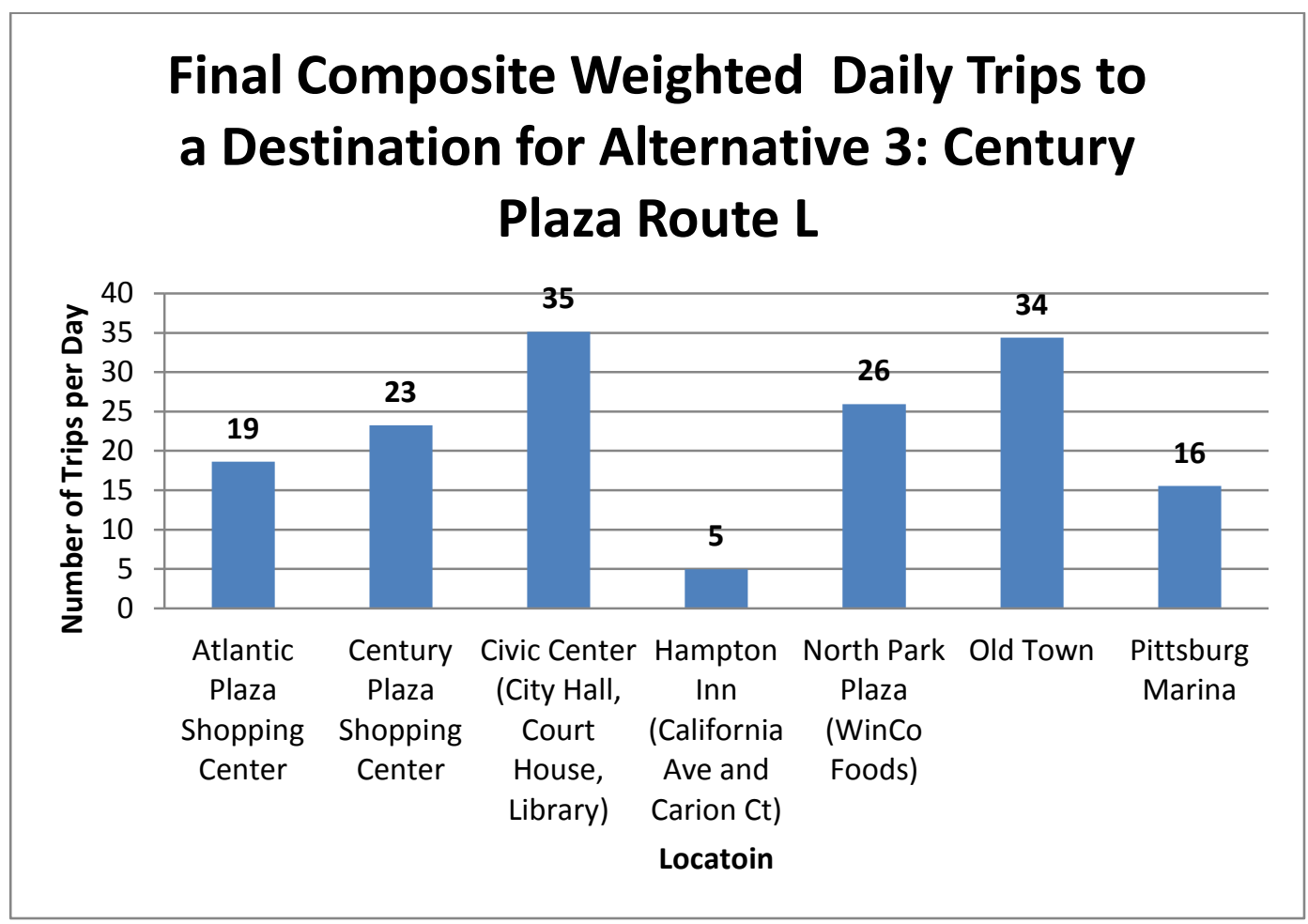

Table 39. ALTERNATIVE 3: FINAL COMPOSITE WEIGHTED DAILY TRIPS TO A DESTINATION

\begin{tabular}{|l|r|r|r|r|}
\hline & $25-44$ & $45-64$ & Over 64 & Sum \\
\hline Atlantic Plaza Shopping Center & 14 & 3 & 1 & 19 \\
\hline Century Plaza Shopping Center & 17 & 4 & 2 & 23 \\
\hline Civic Center (City Hall, Court House, Library) & 26 & 9 & 1 & 35 \\
\hline Hampton Inn (California Ave and Carion Ct) & 5 & 0 & 0 & 5 \\
\hline North Park Plaza (WinCo Foods) & 19 & 5 & 2 & 26 \\
\hline Old Town & 23 & 8 & 3 & 34 \\
\hline Pittsburg Marina & 9 & 4 & 2 & 16 \\
\hline Pittsburg/ Bay Point BART & 0 & 0 & 0 & 0 \\
\hline Senior Center (Presidio Ln) & 0 & 0 & 0 & 0 \\
\hline School (Pittsburg High, Marina Vista) & 0 & 0 & 0 & 0 \\
\hline Sum & 113 & 33 & 11 & 158 \\
\hline
\end{tabular}


Approximately 316 passenger trips are projected per day (assuming roundtrips for the 158 trips to a destination). Since 12 revenue service hours is considered "all day" service and 2 vehicles operate all day, passengers per hour can be calculated as 316 passengers per day divided by 24 hours ( 2 vehicles that operate for 12 hours each). The resulting rate of 13 passengers per hour (pph) provides an hourly performance measure. More importantly, the rate provides a more appropriate means to calculate ridership over shorter operating periods. For example, "Weekday AM and PM Peak Only" service only operates each of the two routes for 6 hours per day and it may not be reasonable to expect 316 passengers (or $26 \mathrm{pph}$ on each route) in those limited hours. Applying the hourly rate of $13 \mathrm{pph}$ for each route creates a projection of 156 total passengers per day, which is a more likely estimate than one that assumes all 316 potential daily riders would schedule their trips around limited service hours. The rate is within the expected 10 to 17 passengers per hour for average shuttles. The groups omitted in the study would likely bring the passenger boarding rates higher. 


\section{COST ANALYSIS}

Table 40 shows the additional required costs for shuttle operation after factoring in potential business contributions and fare revenues. The table adjusts the base costs presented in Table 7 of Evaluation of Costs to reflect the cost of service assuming some funding contributions and revenue recovery. These calculations assume a $\$ 25$ per month business contribution from 20 businesses each year, which totals $\$ 6,000$. Passenger fare revenues were calculated by multiplying the average number of passengers per day by the number of days per year, or the number of passengers per hour by the number of hours per year. The cost recovery is based on basic willingness-to=pay assumptions derived from the survey rather than alternative financing mechanisms.

At a one-dollar fare, some cost expenditures be recovered but not enough to substantially offset the cost of operation. The "Weekday All Day" and the "Weekday All Day with 30 Minute Peak Headways" options, which consists of two routes that each operate 5 days per week for 50 weeks, the routes each return about $\$ 79,000$ per year from the 316 passengers per day. The "Weekday AM and PM Peak Only" option returns about $\$ 39,000$ per year from 13 passengers per hour times 6 hours per day for 250 weekdays times 2 routes. The "Weekday AM and PM Peak, Plus Weekend All Day" option, which consists of two routes that each operate on 6 peak hours every weekday and 2 days over the weekend for 50 weeks, returns about $\$ 71,000$ per year. Revenue recovery and business contributions for service do not substantially decrease annual operating costs, so 
providing the shuttles without fares may be an appropriate choice if providing benefits to the community are more important than minor cost recovery.

Table 40. ALTERNATIVE 3: ANNUAL SHUTTLE COSTS MINUS BUSINESS CONTRIBUTION AND FARES

\begin{tabular}{|c|c|c|c|c|c|}
\hline & Fare: Free & $\$ 0.25$ & $\$ 0.50$ & $\$ 1$ \\
\hline \multirow{4}{*}{$\begin{array}{l}\text { Operating } \\
\text { Cost of } \\
\$ 60 \text { per } \\
\text { Hour }\end{array}$} & $\begin{array}{l}\text { Weekday AM and } \\
\text { PM Peak Only }\end{array}$ & $(\$ 174,000)$ & $(\$ 164,135)$ & $(\$ 154,269)$ & $(\$ 134,539)$ \\
\hline & $\begin{array}{l}\text { Weekday AM and } \\
\text { PM Peak, Plus } \\
\text { Weekend All Day }\end{array}$ & $(\$ 294,000)$ & $(\$ 276,242)$ & $(\$ 258,485)$ & $(\$ 222,970)$ \\
\hline & Weekday All Day & $(\$ 354,000)$ & $(\$ 334,269)$ & $(\$ 314,539)$ & $(\$ 275,078)$ \\
\hline & $\begin{array}{l}\text { Weekday All Day } \\
\text { with } 30 \text { Minute } \\
\text { Peak Headways }\end{array}$ & $(\$ 474,000)$ & $(\$ 454,269)$ & $(\$ 434,539)$ & $(\$ 395,078)$ \\
\hline \multirow{4}{*}{$\begin{array}{l}\text { Operating } \\
\text { Cost of } \\
\$ 70 \text { per } \\
\text { Hour }\end{array}$} & $\begin{array}{l}\text { Weekday AM and } \\
\text { PM Peak Only }\end{array}$ & $(\$ 204,000)$ & $(\$ 194,135)$ & $(\$ 184,269)$ & $(\$ 164,539)$ \\
\hline & $\begin{array}{l}\text { Weekday AM and } \\
\text { PM Peak, Plus } \\
\text { Weekend All Day }\end{array}$ & $(\$ 344,000)$ & $(\$ 326,242)$ & $(\$ 308,485)$ & $(\$ 272,970)$ \\
\hline & Weekday All Day & $(\$ 414,000)$ & $(\$ 394,269)$ & $(\$ 374,539)$ & $(\$ 335,078)$ \\
\hline & $\begin{array}{l}\text { Weekday All Day } \\
\text { with } 30 \text { Minute } \\
\text { Peak Headways }\end{array}$ & $(\$ 554,000)$ & $(\$ 534,269)$ & $(\$ 514,539)$ & $(\$ 475,078)$ \\
\hline \multirow{4}{*}{$\begin{array}{l}\text { Operating } \\
\text { Cost of } \\
\$ 80 \text { per } \\
\text { Hour }\end{array}$} & $\begin{array}{l}\text { Weekday AM and } \\
\text { PM Peak Only }\end{array}$ & $(\$ 234,000)$ & $(\$ 224,135)$ & $(\$ 214,269)$ & $(\$ 194,539)$ \\
\hline & $\begin{array}{l}\text { Weekday AM and } \\
\text { PM Peak, Plus } \\
\text { Weekend All Day }\end{array}$ & $(\$ 394,000)$ & $(\$ 376,242)$ & $(\$ 358,485)$ & $(\$ 322,970)$ \\
\hline & Weekday All Day & $(\$ 474,000)$ & $(\$ 454,269)$ & $(\$ 434,539)$ & $(\$ 395,078)$ \\
\hline & $\begin{array}{l}\text { Weekday All Day } \\
\text { with } 30 \text { Minute } \\
\text { Peak Headways }\end{array}$ & $(\$ 634,000)$ & $(\$ 614,269)$ & $(\$ 594,539)$ & $(\$ 555,078)$ \\
\hline
\end{tabular}




\section{CHAPTER VII. FINDINGS}

Each alternative has a set of benefits and drawbacks. The greatest drawback is availability of funding. In this case, Alternative 1 is the best option. It fulfills the vision of creating a reliable and direct connection between Old Town and Atlantic Plaza along Railroad Avenue, as well as connecting a large number of residential units along the way. The benefit of this alternative is providing a shuttle service with the least cost. Alternative 2 - the Railroad Avenue route with an east-west connection to Century Plaza along California Avenue - has the benefit of expanding connections to the shopping areas in the eastern boundary of the city. The addition of the east-west route actually increases the number of trips made because of access to additional destinations. The difference in daily ridership for the "Weekday All Day" option is an increase in shuttle trips from 121 trips in Alternative 1 to 235 trips in Alternative 2. The drawback operating costs nearly double in this two-route system. Additional housing units served on this route would not significantly offset additional costs. In terms of replacing automobile travel with a viable transit option, Alternative 2 provides greater benefit than Alternative 1. Alternative 3 changes the east-west configuration to Century Plaza. Directing the east-west route through East Leland Road greatly increases the number of homes served by the route and adds connections to Walmart and Los Medanos College. Alternative 2 covers 2667 units (Appendix Table A16) and Alternative 3 (Appendix Table A22) covers 3470 units. Alternative 3 has more benefits than Alternative 2 in terms of accessibility of residential and commercial 
locations. The drawback is Tri Delta serves much of the stretch along East Leland Road, which will necessitate discussion and cooperation. This alternative projects the largest daily ridership of 13 passengers per hour and 316 daily trips for operations of at least 12 hours. Out of these alternatives, Alternative 1 may be the best choice for a new service in terms of costs but not necessarily in terms of improving accessibility through transit. If funding is secured for a two-route structure, however, Alternative 2 and Alternative 3 should be considered to provide greater accessibility.

From an evaluation of benefits outside of costs reductions and passenger counts, the alternatives can be measured in terms of the passenger travel experience. The measure of benefits in this study has included travel time comparisons between shuttle and automobile travel. Travel time is generally comparable to automobile travel, although automobile travel has an edge due to higher average speeds. The Railroad Avenue route features only about a 5 minute difference between automobile and transit travel for a trip from one end of the Railroad Avenue route to the other. Greater travel time differences exist for the east-west routes in Alternative 2 and Alternative 3. Alternative 3 operates at a greater speed than Alternative 2 along the east-west route. However, Alternative 2 serves fewer locations and the speed can be adjusted to provide faster overall travel time from one end of the route to another. Although car travel may be preferred because of travel time savings, transit riders may find other benefits. ITE (2009) refers to studies stating that people place little value on travel time savings 
of less than 2 minutes. Many of the longer travel segments beyond three or four stops exceed this 2-minute window, but users may attain other benefits than just speed of travel. A relaxed travel experience without the stress of driving may be a benefit that is harder to quantify but is just as important to travelers. Some benefits can be evaluated by cost and travel times but other benefits can be found outside of quantitative measures.

Each alternative offers a different number of vehicles removed from the road, which can then be applied to trip savings. In Chapter 4: Study Hypothesis and Vision, reducing automobile trips and emissions was a goal for the shuttle system. Reduction in automobile trips are calculated by applying a factor to projected transit trips. Dividing transit trips by 1.15 to 1.2 provides an estimate for trips diverted to transit during peak hour travel. For off-peak hours, the value is 1.25 to 1.4 (ITE, 2009). Removing vehicles from the road also decreases congestion and improves stop-and-go operations resulting from better free flow. Alternative 1 estimates 122 daily passengers, which would divert 101 trips from automobiles when a factor of 1.2 is applied. Alternative 2, with 234 estimated, would divert 196 trips. Alternative 3, with 316 estimated, would divert 263 trips.

A number of different conclusions can be drawn over which alternative provides the best option for Pittsburg. Benefits in terms of costs, accessibility, travel experience, and reduction in externalities may each be prioritized differently. The choice ultimately comes down to the relative weight and importance placed on different aspects by the decision-makers. 


\section{CHAPTER VIII. CONCLUSIONS AND RECOMMENDATIONS}

Through an examination of academic literature and case studies, this proposal applied principles in transit planning to determine characteristics of the environment where a shuttle system will be established. This study has set forth visions of a shuttle that can serve transportation needs, improve accessibility, meet demands through transit, and reduce externalities. These visions were then addressed through a set of alternatives that explored the effects of shuttle route alignments to key locations, accessibility to different ridership populations along each route configuration, and benefits or drawbacks of mode choices. Further, the preliminary cost analyses could help inform future decision-making. In evaluating alternatives, the benefits and costs of each alternative are weighed.

The least costly alternative appears to be the best choice for Pittsburg at the moment. Starting a new transit service requires careful consideration of capital and recurring costs. Purchasing new vehicles can be a large investment as shown in Chapter 5: Evaluation of Costs. If a grant is available for the acquisition of one electric shuttle, the investment should be made to add an attractive and environmentally sustainable vehicle to represent the new service. If a grant cannot be acquired, an evaluation of the value in vehicle acquisition should be conducted to determine whether a purchase using other funds is warranted. A typical shuttle can still be leased from a third party provider as part of the cost of operation in the contractual agreement. For each alternative, the cost analysis section provides an estimate of the annual operating costs. The startup and operating costs are big 
investments. Thus, the most prudent approach, considering some of the uncertainties in ridership and eBART connection, would be selecting the least expensive alternative, Alternative 1, and slowly branch out the system as the demand for service begins to increase. With the uncertainty in the eBART station along Railroad Avenue, the additional peak period connection to the Pittsburg/Bay Point BART station proposed in Alternative 1 should be considered. Alternative 1 appears to be a sound choice but Alternative 2 and Alternative 3 should be considered if the resources for a larger system are available.

Pittsburg appears to have great opportunities to support a shuttle system, but for now, there are also many uncertainties. The level of passenger support when services start is unclear. Projections performed in this study suggest that ridership would likely be around 10 to 13 passengers per hour (although the figure may be higher). Fostering a good, stable ridership goes beyond estimates and requires a variety of contributions. Providing quality service and vehicles involves examining locations of interests and operating comfortable, attractive shuttles. Promoting transit usage could be just as important. It would involve continually advertising the service and encouraging frequent use.

Creating a passenger-oriented system requires outreach, incentive programs, and a line of communication with the ridership. Outreach should be used to help potential passengers become comfortable with the service. Frequent ride programs, such as transit passes, can increase comfort with the system. In an experiment testing mode change acceptance among commuters, Gould and Zhou 
(2010) found that 70 percent of riders who were offered a three-month transit pass in exchange for their parking passes continued to use transit after the three-month trial ended. Opportunities to attract frequent riders begin with the first ride and require maintenance of a quality service. The cost savings in the use of transit should also be promoted to potential passengers. As fuel prices continue to rise, transit can provide a more cost effective solution for some trips. Even if fuel prices drop, there is a chance that ridership remains (Maghelal, 2011). Regular ridership surveys should be conducted before and after shuttle implementation. Acquiring qualitative information on the rider experiences helps the operator improve service through a customer-oriented approach.

Among the barriers in transit use discussed in literature review, the layout of routes and the placement of stops mitigate the physical barriers in transportation access. Shuttle stops are placed in close proximity to key destinations and origins, including the senior center in the Atlantic Plaza area and Siena Court in the Old Town area. Trolley-style shuttle buses are also considered, which have an aesthetically-pleasing appearance to attract riders. The system provides travel times that could be comparable to automobile travel times at a reasonable fare level compared to automobile costs. Future steps to improve transit quality includes marketing to promote awareness of the service and consideration for transit access in any new design proposals near the shuttle stops. 
Although the development of eBART and transit-oriented units around the station area has yet to commence, the planned location on Railroad Avenue provides great opportunity to establish transit as a viable alternative to reach key nodes in the city. Residents living at TODs are much more likely to use transit than those living even a half mile away from a station. The greater adoption of general transit services among the population of TOD residents bodes well for a shuttle to serve their intracity travel needs. Of those living greater than a half-mile from the eBART station, the shuttle would provide a "first-mile and last-mile" service to connect residents to the regional rail option and encourage greater transit use.

The shuttle system has the opportunity to grow along with Pittsburg. Although Alternative 1 appears to be the most appropriate choice in the current environment considering financial and developmental constraints, the other alternatives should be reconsidered when the development produces an even greater demand for better transit service or when funding sources become available for a more extensive shuttle network. As ridership begins to stabilize and new demand starts to grow (or if funding becomes available), the expansion of an east-west route proposed in Alternative 2 and 3 should be considered. And as the shuttle system matures, these plans should continue to be refined to reflect the needs potential riders. 


\section{APPENDIX A}

\section{AA. HEADWAY CALCULATIONS}

MINIMUM TRAVEL TIME REQUIRED TO COMPLETE A ROUTE

$$
T_{\min }=\frac{2 L}{V_{o}}+t t
$$

Where,

$T_{\text {min }}=$ minimum travel time

$L=$ one way route length

$V_{o}=$ operating speed

$t t=$ driver's terminal time as a percent of travel time

Table A 1. MINIMUM TRAVEL TIME (ROUTE LEVEL EXAMINATION METHOD)

\begin{tabular}{|c|c|c|c|c|c|}
\hline & & $\begin{array}{l}\text { Speed } \\
\text { (Vo) }\end{array}$ & $\begin{array}{l}\text { Route } \\
\text { Length }(\mathrm{L})\end{array}$ & $\begin{array}{l}\text { Terminal } \\
\text { Time (tt) }\end{array}$ & $\begin{array}{l}\text { Minimum } \\
\text { Travel Time }\end{array}$ \\
\hline & & in $\mathrm{mph}$ & in miles & in minutes & in minutes \\
\hline $\begin{array}{l}\text { Alternative 1: } \\
\text { Railroad Avenue } \\
\text { Route }\end{array}$ & $\begin{array}{l}\text { Railroad } \\
\text { Avenue Route }\end{array}$ & 14 & 2.6 & 3.6 & 25.9 \\
\hline Alternative 2: & $\begin{array}{l}\text { Railroad } \\
\text { Avenue Route }\end{array}$ & 14 & 2.6 & 3.6 & 25.9 \\
\hline Route C & $\begin{array}{l}\text { Century } \\
\text { Plaza Route }\end{array}$ & 10 & 3.6 & 6.5 & 49.7 \\
\hline Alternative 3: & $\begin{array}{l}\text { Railroad } \\
\text { Avenue Route }\end{array}$ & 14 & 2.6 & 3.6 & 25.9 \\
\hline Route L & $\begin{array}{l}\text { Century } \\
\text { Plaza Route }\end{array}$ & 13 & 4.7 & 6.5 & 49.9 \\
\hline
\end{tabular}

*Terminal Time is $15 \%$ travel time (Route Length divided by Speed) 


$$
N>\frac{T}{h}
$$

Where,

$T \geq T_{\min }$, and $T$ is rounded to the nearest 10 minute interval

$N=$ number of vehicles required

$h=$ desired headway

Table A 2. NUMBER OF REQUIRED VEHICLES

\begin{tabular}{|c|c|c|c|c|}
\hline & & $\begin{array}{l}\text { Minimum } \\
\text { Travel Time }\end{array}$ & $\begin{array}{l}30 \text { min } \\
\text { Headway }\end{array}$ & $\begin{array}{l}60 \text { min } \\
\text { Headway }\end{array}$ \\
\hline & & in minutes & in vehicles & in vehicles \\
\hline $\begin{array}{l}\text { Alternative 1: } \\
\text { Railroad Avenue } \\
\text { Route }\end{array}$ & $\begin{array}{l}\text { Railroad } \\
\text { Avenue Route }\end{array}$ & 27.8 & 1 & 1 \\
\hline Alternative 2: & $\begin{array}{l}\text { Railroad } \\
\text { Avenue Route }\end{array}$ & 27.8 & 1 & 1 \\
\hline Route C & $\begin{array}{l}\text { Century } \\
\text { Plaza Route }\end{array}$ & 49.7 & 2 & 1 \\
\hline Alternative 3: & $\begin{array}{l}\text { Railroad } \\
\text { Avenue Route }\end{array}$ & 27.8 & 1 & 1 \\
\hline Route L & $\begin{array}{l}\text { Century } \\
\text { Plaza Route }\end{array}$ & 49.9 & 2 & 1 \\
\hline
\end{tabular}




\section{AB. STATION-TO-STATION TRAVEL TIME}

If a vehicle is capable of reaching determined speeds for all distances between stops, the following equations are applied:

Distance Where Determined Speed is Reached

$$
S_{c}=v^{2} \max \left(\frac{1}{a}+\frac{1}{b}\right)
$$

Where,

$S_{c}[\mathrm{ft}]$ is the distance between stations where maximum speed is attained

$v_{\max }$ is the maximum speed

$a\left[\mathrm{ft} / \mathrm{sec}^{\wedge} 2\right]$ is acceleration rate $\left(4 \mathrm{ft} / \mathrm{sec}^{\wedge} 2\right)$

$b\left[\mathrm{ft} / / \mathrm{sec}^{\wedge} 2\right]$ is deceleration rate $\left(4 \mathrm{ft} / \mathrm{sec}^{\wedge} 2\right)$

\section{$\underline{\text { Travel Time between Stations }}$}

$$
T_{s}=\frac{v_{\max }}{2}\left(\frac{1}{a}+\frac{1}{b}\right)+\frac{S}{v_{\max }}
$$

Where,

$T_{S}$ is travel time between stations

$S$ [ft] is spacing greater than $S_{c}$

$v_{\max }$ is the maximum speed

$a\left[\mathrm{ft} / / \mathrm{sec}^{\wedge} 2\right]$ is acceleration rate $\left(4 \mathrm{ft} / \mathrm{sec}^{\wedge} 2\right)$

$b\left[\mathrm{ft} . / \mathrm{sec}^{\wedge} 2\right]$ is deceleration rate $\left(4 \mathrm{ft} / \mathrm{sec}^{\wedge} 2\right)$ 


\section{ALTERNATIVE 1: STATION-TO- STATION TRAVEL TIME}

Table A 3. STATION-TO-STATION TRAVEL TIME CALCULATION FOR RAILROAD AVENUE ROUTE

\begin{tabular}{|c|c|c|c|c|c|c|c|c|}
\hline From & To & Feet & $\begin{array}{l}\mathrm{Sc}=(\mathrm{ft}) \\
\text { distance } \\
\mathrm{b} / \mathrm{w} \\
\text { stations, } \\
\text { max } \\
\text { speed } \\
\text { attained }\end{array}$ & $\begin{array}{l}\mathrm{S}=(\mathrm{ft}) \\
\text { spacing } \\
\text { greater } \\
\text { than } \mathrm{Sc}\end{array}$ & $\begin{array}{l}\mathrm{v} \max \\
= \\
(\mathrm{ft} / \mathrm{sec}) \\
\max \\
\text { speed }\end{array}$ & $\begin{array}{l}a= \\
\left(\mathrm{ft} / \mathrm{sec}^{\wedge}\right. \\
2) \\
\text { accel } \\
\text { rate }\end{array}$ & $\begin{array}{l}\mathrm{b}= \\
(\mathrm{ft} / \mathrm{sec} \\
\wedge 2) \\
\text { decel } \\
\text { rate }\end{array}$ & $\begin{array}{l}\text { Ts }= \\
\text { Station } \\
\text { to } \\
\text { Station } \\
\text { Travel } \\
\text { Time } \\
\text { (sec) }\end{array}$ \\
\hline Marina & $\begin{array}{l}\text { Marina } \\
\text { Housing }\end{array}$ & 2200 & 165 & 2035 & 21 & 4 & 4 & 104 \\
\hline $\begin{array}{l}\text { Marina } \\
\text { Housing }\end{array}$ & $\begin{array}{l}\text { Siena } \\
\text { Court }\end{array}$ & 2800 & 165 & 2635 & 21 & 4 & 4 & 133 \\
\hline $\begin{array}{l}\text { Siena } \\
\text { Court }\end{array}$ & $\begin{array}{l}\text { Civic } \\
\text { Center }\end{array}$ & 4200 & 165 & 4035 & 21 & 4 & 4 & 202 \\
\hline $\begin{array}{l}\text { Civic } \\
\text { Center }\end{array}$ & $\begin{array}{l}\text { Railroad } \\
\text { Plaza }\end{array}$ & 2700 & 165 & 2535 & 21 & 4 & 4 & 129 \\
\hline $\begin{array}{l}\text { Railroad } \\
\text { Plaza }\end{array}$ & $\begin{array}{l}\text { Senior } \\
\text { Center }\end{array}$ & 3000 & 165 & 2835 & 21 & 4 & 4 & 143 \\
\hline $\begin{array}{l}\text { Senior } \\
\text { Center }\end{array}$ & $\begin{array}{l}\text { Atlantic } \\
\text { Plaza } 1\end{array}$ & 1500 & 165 & 1335 & 21 & 4 & 4 & 70 \\
\hline $\begin{array}{l}\text { Atlantic } \\
\text { Plaza 1 }\end{array}$ & $\begin{array}{l}\text { Atlantic } \\
\text { Plaza } 2\end{array}$ & 1300 & 165 & 1135 & 21 & 4 & 4 & 60 \\
\hline $\begin{array}{l}\text { Atlantic } \\
\text { Plaza } 2\end{array}$ & $\begin{array}{l}\text { Railroad } \\
\text { Ave }\end{array}$ & 2400 & 165 & 2235 & 21 & 4 & 4 & 114 \\
\hline $\begin{array}{l}\text { Railroad } \\
\text { Ave }\end{array}$ & $\begin{array}{l}\text { Old } \\
\text { Town }\end{array}$ & 6000 & 165 & 5835 & 21 & 4 & 4 & 289 \\
\hline \multirow[t]{3}{*}{$\begin{array}{l}\text { Old } \\
\text { Town }\end{array}$} & Marina & 1600 & 165 & 1435 & 21 & 4 & 4 & 75 \\
\hline & & & & & & & Sum & 1320 \\
\hline & & & & & & & & $22 \min$ \\
\hline
\end{tabular}




\section{ALTERNATIVE 2: STATION-TO-STATION TRAVEL TIME}

Table A 4. STATION-TO-STATION TRAVEL TIME CALCULATION FOR CENTURY PLAZA ROUTE C

\begin{tabular}{|c|c|c|c|c|c|c|c|c|}
\hline From & To & Feet & $\begin{array}{l}\mathrm{Sc}=(\mathrm{ft}) \\
\text { distance } \\
\mathrm{b} / \mathrm{w} \\
\text { stations, } \\
\text { max } \\
\text { speed } \\
\text { attained }\end{array}$ & $\begin{array}{l}\mathrm{S}=(\mathrm{ft}) \\
\text { spacing } \\
\text { greater } \\
\text { than } \mathrm{Sc}\end{array}$ & $\begin{array}{l}v \max \\
= \\
(\mathrm{ft} / \mathrm{sec}) \\
\max \\
\text { speed }\end{array}$ & $\begin{array}{l}a= \\
(\mathrm{ft} / \mathrm{sec} \\
\wedge 2) \\
\text { accel } \\
\text { rate }\end{array}$ & $\begin{array}{l}\mathrm{b}= \\
\left(\mathrm{ft} / \sec ^{\wedge} 2\right) \\
\text { decel } \\
\text { rate }\end{array}$ & $\begin{array}{l}\text { Ts }= \\
\text { Station } \\
\text { to } \\
\text { Station } \\
\text { Travel } \\
\text { Time } \\
(\mathrm{sec}) \\
\end{array}$ \\
\hline $\begin{array}{l}\text { Civic } \\
\text { Center }\end{array}$ & $\begin{array}{l}\text { North } \\
\text { Park } \\
\text { Plaza }\end{array}$ & 10600 & 165 & 10435 & 15 & 4 & 4 & 715 \\
\hline $\begin{array}{l}\text { North } \\
\text { Park } \\
\text { Plaza }\end{array}$ & $\begin{array}{l}\text { Century } \\
\text { Plaza } 1\end{array}$ & 7600 & 165 & 7435 & 15 & 4 & 4 & 511 \\
\hline $\begin{array}{l}\text { Century } \\
\text { Plaza } 1\end{array}$ & $\begin{array}{l}\text { Century } \\
\text { Plaza } 2\end{array}$ & 1600 & 165 & 1435 & 15 & 4 & 4 & 101 \\
\hline $\begin{array}{l}\text { Century } \\
\text { Plaza } 2\end{array}$ & $\begin{array}{l}\text { North } \\
\text { Park } \\
\text { Plaza }\end{array}$ & 7600 & 165 & 7435 & 15 & 4 & 4 & 511 \\
\hline \multirow[t]{3}{*}{$\begin{array}{l}\text { North } \\
\text { Park } \\
\text { Plaza } \\
\end{array}$} & $\begin{array}{l}\text { Civic } \\
\text { Center }\end{array}$ & 10600 & 165 & 10435 & 15 & 4 & 4 & 715 \\
\hline & & & & & & & Sum & 2553 \\
\hline & & & & & & & & $43 \mathrm{~min}$ \\
\hline
\end{tabular}




\section{ALTERNATIVE 3: STATION-TO-STATION TRAVEL TIME}

Table A 5. STATION-TO-STATION TRAVEL TIME CALCULATION FOR CENTURY PLAZA ROUTE L

\begin{tabular}{|c|c|c|c|c|c|c|c|c|}
\hline From & To & Feet & $\begin{array}{l}\mathrm{Sc}=(\mathrm{ft}) \\
\text { distance } \\
\mathrm{b} / \mathrm{w} \\
\text { stations, } \\
\text { max } \\
\text { speed } \\
\text { attained }\end{array}$ & $\begin{array}{l}\mathrm{S}=(\mathrm{ft}) \\
\text { spacing } \\
\text { greater } \\
\text { than Sc }\end{array}$ & $\begin{array}{l}\mathrm{v} \max \\
= \\
(\mathrm{ft} / \mathrm{sec}) \\
\max \\
\text { speed }\end{array}$ & $\begin{array}{l}a= \\
\text { (ft/sec } \\
\left.\wedge_{2}\right) \\
\text { accel } \\
\text { rate }\end{array}$ & $\begin{array}{l}b= \\
(\mathrm{ft} / \mathrm{se} \\
\left.\mathrm{c}^{\wedge} 2\right) \\
\text { decel } \\
\text { rate }\end{array}$ & $\begin{array}{l}\text { Ts }= \\
\text { Station } \\
\text { to } \\
\text { Station } \\
\text { Travel } \\
\text { Time } \\
\text { (sec) }\end{array}$ \\
\hline $\begin{array}{l}\text { Civic } \\
\text { Center }\end{array}$ & $\begin{array}{l}\text { Railroad } \\
\text { Plaza }\end{array}$ & 2500 & 165 & 2335 & 19 & 4 & 4 & 127 \\
\hline $\begin{array}{l}\text { Railroad } \\
\text { Plaza }\end{array}$ & Harbor St & 2900 & 165 & 2735 & 19 & 4 & 4 & 148 \\
\hline Harbor St & $\begin{array}{l}\text { Wood } \\
\text { Grove } \\
\text { Apts }\end{array}$ & 1800 & 165 & 1635 & 19 & 4 & 4 & 90 \\
\hline $\begin{array}{l}\text { Wood } \\
\text { Grove } \\
\text { Apts }\end{array}$ & $\begin{array}{l}\text { Piedmont } \\
\text { Way }\end{array}$ & 1300 & 165 & 1135 & 19 & 4 & 4 & 64 \\
\hline $\begin{array}{l}\text { Piedmont } \\
\text { Way }\end{array}$ & Walmart & 2200 & 165 & 2035 & 19 & 4 & 4 & 111 \\
\hline Walmart & $\begin{array}{l}\text { North Park } \\
\text { Plaza }\end{array}$ & 2200 & 165 & 2035 & 19 & 4 & 4 & 111 \\
\hline $\begin{array}{l}\text { NorthPark } \\
\text { Plaza }\end{array}$ & $\begin{array}{l}\text { Atlantic } \\
\text { Plaza 1 }\end{array}$ & 7600 & 165 & 7435 & 19 & 4 & 4 & 395 \\
\hline $\begin{array}{l}\text { Atlantic } \\
\text { Plaza 1 }\end{array}$ & $\begin{array}{l}\text { Atlantic } \\
\text { Plaza 2 }\end{array}$ & 1600 & 165 & 1435 & 19 & 4 & 4 & 80 \\
\hline $\begin{array}{l}\text { Atlantic } \\
\text { Plaza } 2\end{array}$ & $\begin{array}{l}\text { North Park } \\
\text { Plaza }\end{array}$ & 7600 & 165 & 7435 & 19 & 4 & 4 & 395 \\
\hline $\begin{array}{l}\text { NorthPark } \\
\text { Plaza }\end{array}$ & $\begin{array}{l}\text { Los } \\
\text { Medanos }\end{array}$ & 6800 & 165 & 6635 & 19 & 4 & 4 & 353 \\
\hline $\begin{array}{l}\text { Los } \\
\text { Medanos }\end{array}$ & $\begin{array}{l}\text { Piedmont } \\
\text { Way }\end{array}$ & 4600 & 165 & 4435 & 19 & 4 & 4 & 237 \\
\hline $\begin{array}{l}\text { Piedmont } \\
\text { Way }\end{array}$ & Freed Ave & 2000 & 165 & 1835 & 19 & 4 & 4 & 101 \\
\hline Freed Ave & $\begin{array}{l}\text { Railroad } \\
\text { Ave }\end{array}$ & 4200 & 165 & 4035 & 19 & 4 & 4 & 216 \\
\hline \multirow[t]{3}{*}{$\begin{array}{l}\text { Railroad } \\
\text { Ave }\end{array}$} & $\begin{array}{l}\text { Civic } \\
\text { Center }\end{array}$ & 2300 & 165 & 2135 & 19 & 4 & 4 & 117 \\
\hline & & & & & & & Sum & 2547 \\
\hline & & & & & & & & $42 \mathrm{~min}$ \\
\hline
\end{tabular}




\section{AC. WEIGHTED TRIPS (BY AGE GROUP)}

\section{SURVEY ADJUSTMENT FACTORS AND POPULATION WEIGHT}

Table A 6. WEIGHT FACTORS

\begin{tabular}{|l|l|l|l|}
\hline & $\begin{array}{l}\text { Survey } \\
\text { Proportional } \\
\text { Distribution }\end{array}$ & $\begin{array}{l}\text { Census } \\
\text { Proportional } \\
\text { Distribution* }\end{array}$ & $\begin{array}{l}\text { Weight } \\
\text { Factor* }\end{array}$ \\
\hline Under 24 & $7 \%$ & $38 \%$ & 5.35 \\
\hline $25-44$ & $31 \%$ & $29 \%$ & 0.94 \\
\hline $45-64$ & $48 \%$ & $24 \%$ & 0.50 \\
\hline Over 64 & $14 \%$ & $9 \%$ & 0.60 \\
\hline Total & $100 \%$ & $100 \%$ & 1.00 \\
\hline
\end{tabular}

*Source: Census 2010

** Weight Factor $=\frac{\text { Census }}{\text { Survey }}$

Table A 7. WEIGHTED TRIPS FOR 25 TO 44 AGE GROUP

\begin{tabular}{|l|l|l|l|l|l|}
\hline Age 25-44 & \multicolumn{5}{|l|}{ Total responses: 28} \\
\hline & $\begin{array}{l}\text { Did } \\
\text { Not } \\
\text { Make } \\
\text { Trip }\end{array}$ & $\begin{array}{l}\text { Made } \\
\text { Trip }\end{array}$ & $\begin{array}{l}\text { Number } \\
\text { of Trips }\end{array}$ & $\begin{array}{l}\text { Trips per } \\
\text { Person in } \\
\text { Age Group } \\
\text { per Day }\end{array}$ & $\begin{array}{l}\text { Weighted } \\
\text { Trips per } \\
\text { Person } \\
\text { per Day }\end{array}$ \\
\hline Atlantic Plaza Shopping Center & 17 & 11 & 35 & 0.18 & 0.17 \\
\hline Century Plaza Shopping Center & 16 & 12 & 27 & 0.14 & 0.13 \\
\hline $\begin{array}{l}\text { Civic Center (City Hall, Court } \\
\text { House, Library) }\end{array}$ & 17 & 11 & 46 & 0.23 & 0.22 \\
\hline $\begin{array}{l}\text { Hampton Inn (California Ave and } \\
\text { Carion Ct) }\end{array}$ & 26 & 2 & 8 & 0.04 & 0.04 \\
\hline North Park Plaza (WinCo Foods) & 17 & 11 & 31 & 0.16 & 0.15 \\
\hline Old Town & 14 & 14 & 43 & 0.22 & 0.21 \\
\hline Pittsburg Marina & 22 & 6 & 16 & 0.08 & 0.08 \\
\hline Pittsburg/ Bay Point BART & 20 & 8 & 46 & 0.23 & 0.22 \\
\hline Senior Center (Presidio Ln) & 25 & 3 & 14 & 0.07 & 0.07 \\
\hline $\begin{array}{l}\text { School (Pittsburg High, Marina } \\
\text { Vista) }\end{array}$ & 27 & 1 & 7 & 0.04 & 0.03 \\
\hline
\end{tabular}




\begin{tabular}{|l|l|l|l|l|l|}
\hline Age 45-64 & \multicolumn{4}{l}{ Total responses: 47 } \\
\hline & $\begin{array}{l}\text { Did } \\
\text { Not } \\
\text { Make } \\
\text { Trip }\end{array}$ & $\begin{array}{l}\text { Made } \\
\text { Trip }\end{array}$ & $\begin{array}{l}\text { Number } \\
\text { of Trips }\end{array}$ & $\begin{array}{l}\text { Trips per } \\
\text { Person in } \\
\text { Age Group } \\
\text { per Day }\end{array}$ & $\begin{array}{l}\text { Weighted } \\
\text { Trips per } \\
\text { Person } \\
\text { per Day }\end{array}$ \\
\hline Atlantic Plaza Shopping Center & 31 & 16 & 29 & 0.09 & 0.04 \\
\hline Century Plaza Shopping Center & 31 & 16 & 26 & 0.08 & 0.04 \\
\hline $\begin{array}{l}\text { Civic Center (City Hall, Court } \\
\text { House, Library) }\end{array}$ & 29 & 18 & 58 & 0.18 & 0.09 \\
\hline $\begin{array}{l}\text { Hampton Inn (California Ave and } \\
\text { Carion Ct) }\end{array}$ & 47 & 0 & 0 & 0.00 & 0.00 \\
\hline North Park Plaza (WinCo Foods) & 33 & 14 & 29 & 0.09 & 0.04 \\
\hline Old Town & 32 & 15 & 55 & 0.17 & 0.08 \\
\hline Pittsburg Marina & 36 & 11 & 27 & 0.08 & 0.04 \\
\hline Pittsburg/ Bay Point BART & 35 & 12 & 49 & 0.15 & 0.08 \\
\hline Senior Center (Presidio Ln) & 44 & 3 & 0 & 0.00 & 0.00 \\
\hline $\begin{array}{l}\text { School (Pittsburg High, Marina } \\
\text { Vista) }\end{array}$ & 43 & 4 & 17 & 0.05 & 0.03 \\
\hline
\end{tabular}

Table A 9. WEIGHTED TRIPS FOR OVER 64 AGE GROUP

\begin{tabular}{|l|l|l|l|l|l|}
\hline Age Over 64 & \multicolumn{6}{|l|}{ Total Responses: 14} \\
\hline & $\begin{array}{l}\text { Did } \\
\text { Not } \\
\text { Make } \\
\text { Trip }\end{array}$ & $\begin{array}{l}\text { Made } \\
\text { Trip }\end{array}$ & $\begin{array}{l}\text { Number } \\
\text { of Trips }\end{array}$ & $\begin{array}{l}\text { Trips per } \\
\text { Person in } \\
\text { Age Group } \\
\text { per Day }\end{array}$ & $\begin{array}{l}\text { Weighted } \\
\text { Trips per } \\
\text { Person } \\
\text { per Day }\end{array}$ \\
\hline Atlantic Plaza Shopping Center & 10 & 4 & 5 & 0.05 & 0.03 \\
\hline Century Plaza Shopping Center & 11 & 3 & 7 & 0.07 & 0.04 \\
\hline $\begin{array}{l}\text { Civic Center (City Hall, Court } \\
\text { House, Library) }\end{array}$ & 13 & 1 & 3 & 0.03 & 0.02 \\
\hline $\begin{array}{l}\text { Hampton Inn (California Ave and } \\
\text { Carion Ct) }\end{array}$ & 14 & 0 & 0 & 0.00 & 0.00 \\
\hline North Park Plaza (WinCo Foods) & 11 & 3 & 6 & 0.06 & 0.04 \\
\hline Old Town & 11 & 3 & 12 & 0.12 & 0.07 \\
\hline Pittsburg Marina & 12 & 2 & 7 & 0.07 & 0.04 \\
\hline Pittsburg/ Bay Point BART & 13 & 1 & 4 & 0.04 & 0.02 \\
\hline Senior Center (Presidio Ln) & 12 & 2 & 5 & 0.05 & 0.03 \\
\hline $\begin{array}{l}\text { School (Pittsburg High, Marina } \\
\text { Vista) }\end{array}$ & 13 & 1 & 2 & 0.02 & 0.01 \\
\hline
\end{tabular}




\section{AD. ALTERNATIVE 1: RIDERSHIP PROJECTION}

\section{HOUSING UNITS}

Table A 10. ALTERNATIVE 1: HOUSING UNITS WITHIN $1 / 4$ MILE OF PROPOSED SHUTTLE ROUTES

\begin{tabular}{|l|r|l|l|}
\hline Area & Units & Land_Use & Name \\
\hline Atlantic & 118 & Low Density Residential & \\
\hline Atlantic & 26 & Low Density Residential & \\
\hline Atlantic & 170 & Low Density Residential & \\
\hline Atlantic & 118 & Low Density Residential & \\
\hline Atlantic & 45 & Medium Density Residential & \\
\hline Atlantic & 93 & Medium Density Residential & \\
\hline Atlantic & 204 & High Density Residential & Cornerstone Apts \\
\hline Atlantic & 76 & Medium Density Residential & Pittsburg Park Apts \\
\hline Atlantic & 125 & Medium Density Residential & Fox Creek Apts \\
\hline Atlantic & 48 & High Density Residential & Villa Serena Apts \\
\hline Atlantic & 165 & Medium Density Residential & Lido Square Apts \\
\hline Civic & 50 & Low Density Residential & \\
\hline Civic & 56 & Low Density Residential & \\
\hline Civic & 101 & Low Density Residential & \\
\hline Civic & 153 & Low Density Residential & \\
\hline Marina & 26 & Low Density Residential & \\
\hline Marina & 200 & High Density Residential & Marina Heights Apts \\
\hline Old Town & 90 & Low Density Residential & \\
\hline Old Town & 116 & Low Density Residential & \\
\hline Old Town & 40 & Low Density Residential & \\
\hline Old Town & 120 & Medium Density Residential & \\
\hline Old Town & 25 & High Density Residential & East Santa Fe Apts \\
\hline Old Town & 75 & High Density Residential & Vidrio \\
\hline Base Total & 2240 & & \\
\hline
\end{tabular}




\section{POTENTIAL TRIPS}

Table A 11. ALTERNATIVE 1: POPULATION OF POTENTIAL TRIP-MAKERS

\begin{tabular}{|l|r|r|r|r|l|}
\hline Age & $\begin{array}{l}\text { Under } \\
24\end{array}$ & $25-44$ & $\begin{array}{r}45-64 \\
\text { Over }\end{array}$ & Sum \\
& & 64 & \\
\hline Atlantic Plaza Shopping Center & 0 & 979 & 820 & 288 & 2087 \\
\hline Century Plaza Shopping Center & 0 & 2084 & 1745 & 613 & 4443 \\
\hline Civic Center (City Hall, Court House, Library) & 0 & 1749 & 1465 & 515 & 3729 \\
\hline Hampton Inn (California Ave and Carion Ct) & 0 & 2084 & 1745 & 613 & 4443 \\
\hline North Park Plaza (WinCo Foods) & 0 & 2084 & 1745 & 613 & 4443 \\
\hline Old Town & 0 & 1651 & 1382 & 486 & 3519 \\
\hline Pittsburg Marina & 0 & 1874 & 1569 & 551 & 3995 \\
\hline Pittsburg/ Bay Point BART & 0 & 2084 & 1745 & 613 & 4443 \\
\hline Senior Center (Presidio Ln) & 0 & 979 & 820 & 288 & 2087 \\
\hline School (Pittsburg High, Marina Vista) & 0 & 1651 & 1382 & 486 & 3519 \\
\hline Sum & 0 & 17221 & 14421 & 5065 & \\
\hline
\end{tabular}

$$
L=P *[H *(U-A)]
$$

Where,

$L=$ population living within $1 / 4$ mile of a shuttle route that would make trips (Table A11)

$P=$ proportion of population in age group $(0.29$ for $25-44 ; 0.24$ for $45-63 ; 0.09$ for Over 64) (Census, 2010)

$H=$ average household size in Pittsburg (3.22)(Census, 2010)

$U=$ total housing units within $1 / 4$ mile of shuttle routes (2240) (Table A10)

$A=$ total number of units in area of trip origin (Table A10) 
Table A 12. WEIGHTED TRIPS (BY AGE GROUP)

\begin{tabular}{|c|c|c|c|c|}
\hline & \multicolumn{4}{|c|}{$\begin{array}{l}\text { Weighted daily trips made by } \\
\text { the age group }\end{array}$} \\
\hline & $\begin{array}{l}\text { Under } \\
24\end{array}$ & $25-44$ & $45-64$ & $\begin{array}{l}\text { Over } \\
64\end{array}$ \\
\hline Atlantic Plaza Shopping Center & 0 & 0.17 & 0.04 & 0.03 \\
\hline Century Plaza Shopping Center & 0 & 0.13 & 0.04 & 0.04 \\
\hline Civic Center (City Hall, Court House, Library) & 0 & 0.22 & 0.09 & 0.02 \\
\hline Hampton Inn (California Ave and Carion Ct) & 0 & 0.04 & 0.00 & 0.00 \\
\hline North Park Plaza (WinCo Foods) & 0 & 0.15 & 0.04 & 0.04 \\
\hline Old Town & 0 & 0.21 & 0.08 & 0.07 \\
\hline Pittsburg Marina & 0 & 0.08 & 0.04 & 0.04 \\
\hline Pittsburg/ Bay Point BART & 0 & 0.22 & 0.08 & 0.02 \\
\hline Senior Center (Presidio Ln) & 0 & 0.07 & 0.00 & 0.03 \\
\hline School (Pittsburg High, Marina Vista) & 0 & 0.03 & 0.03 & 0.01 \\
\hline
\end{tabular}

Table A 13. ALTERNATIVE 1: POTENTIAL TRIPS MADE BY POPULATION

\begin{tabular}{|c|c|c|c|c|c|}
\hline & $\begin{array}{l}\text { Under } \\
24\end{array}$ & $25-44$ & $45-64$ & $\begin{array}{l}\text { Over } \\
64\end{array}$ & Sum \\
\hline Atlantic Plaza Shopping Center & 0 & 7 & 1 & 0 & 8 \\
\hline Century Plaza Shopping Center & 0 & 11 & 3 & 1 & 15 \\
\hline Civic Center (City Hall, Court House, Library) & 0 & 16 & 5 & 0 & 21 \\
\hline Hampton Inn (California Ave and Carion Ct) & 0 & 3 & 0 & 0 & 3 \\
\hline North Park Plaza (WinCo Foods) & 0 & 12 & 3 & 1 & 16 \\
\hline Old Town & 0 & 14 & 5 & 1 & 20 \\
\hline Pittsburg Marina & 0 & 6 & 3 & 1 & 9 \\
\hline Pittsburg/ Bay Point BART & 0 & 18 & 5 & 1 & 24 \\
\hline Senior Center (Presidio Ln) & 0 & 3 & 0 & 0 & 3 \\
\hline School (Pittsburg High, Marina Vista) & 0 & 2 & 1 & 0 & 4 \\
\hline Sum & 0 & 91 & 27 & 6 & 124 \\
\hline
\end{tabular}

$$
T=\operatorname{HBShop}(L * W)
$$

Where,

$T=$ potential transit trips to a destination (Table A13)

HBShop $=$ Home-based-shopping trip made by transit (4 percent of trips)*

$L=$ population living within $1 / 4$ mile of a shuttle route that would make trips (Table A11)

$W=$ weighted daily trips by age group (Table A12)

*Source: Contra Costa Transportation Authority (2003) 
Table A 14. ALTERNATIVE 1: POTENTIAL TRIPS FROM SENIOR UNITS

\begin{tabular}{|l|l|}
\hline Trips from Senior Units & \\
\hline Atlantic Plaza Shopping Center & 0.38 \\
\hline Century Plaza Shopping Center & 0.54 \\
\hline Civic Center (City Hall, Court House, Library) & 0.23 \\
\hline Hampton Inn (California Ave and Carion Ct) & 0.00 \\
\hline North Park Plaza (WinCo Foods) & 0.46 \\
\hline Old Town & 0.92 \\
\hline Pittsburg Marina & 0.54 \\
\hline Pittsburg/ Bay Point BART & 0.31 \\
\hline Senior Center (Presidio Ln) & 0.38 \\
\hline School (Pittsburg High, Marina Vista) & 0.15 \\
\hline Sum & 3.91 \\
\hline
\end{tabular}

FINAL ADJUSTED POTENTIAL TRIPS MADE BY THE POPULATION

Table A 15. ALTERNATIVE 1: FINAL ADJUSTED POTENTIAL TRIPS MADE BY POPULATION

\begin{tabular}{|c|c|c|c|c|c|}
\hline & $\begin{array}{l}\text { Under } \\
24\end{array}$ & $25-44$ & $45-64$ & $\begin{array}{l}\text { Over } \\
64\end{array}$ & Sum \\
\hline Atlantic Plaza Shopping Center & 0 & 7 & 1 & 1 & 9 \\
\hline Century Plaza Shopping Center & 0 & 11 & 3 & 2 & 15 \\
\hline Civic Center (City Hall, Court House, Library) & 0 & 16 & 5 & 1 & 21 \\
\hline Hampton Inn (California Ave and Carion Ct) & 0 & 3 & 0 & 0 & 3 \\
\hline North Park Plaza (WinCo Foods) & 0 & 12 & 3 & 1 & 17 \\
\hline Old Town & 0 & 14 & 5 & 2 & 21 \\
\hline Pittsburg Marina & 0 & 6 & 3 & 1 & 10 \\
\hline Pittsburg/ Bay Point BART & 0 & 0 & 0 & 0 & 0 \\
\hline Senior Center (Presidio Ln) & 0 & 0 & 0 & 0 & 0 \\
\hline School (Pittsburg High, Marina Vista) & 0 & 0 & 0 & 0 & 0 \\
\hline Sum $^{*}$ & 0 & 68 & 20 & 8 & 96 \\
\hline
\end{tabular}

*The sum of Table A13 and A14 minus trips to areas with uncertain conditions. 


\section{AE. ALTERNATIVE 2: RIDERSHIP PROJECTION}

\section{HOUSING UNITS}

Table A 16. ALTERNATIVE 2: HOUSING UNITS WITHIN 1/4 MILE OF PROPOSED SHUTTLE ROUTES

\begin{tabular}{|l|r|l|l|}
\hline Area & Units & Land_Use & Name \\
\hline Atlantic & 118 & Low Density Residential & \\
\hline Atlantic & 26 & Low Density Residential & \\
\hline Atlantic & 170 & Low Density Residential & \\
\hline Atlantic & 118 & Low Density Residential & \\
\hline Atlantic & 45 & Medium Density Residential & \\
\hline Atlantic & 93 & Medium Density Residential & \\
\hline Atlantic & 204 & High Density Residential & Cornerstone Apts \\
\hline Atlantic & 76 & Medium Density Residential & Pittsburg Park Apts \\
\hline Atlantic & 125 & Medium Density Residential & Fox Creek Apts \\
\hline Atlantic & 48 & High Density Residential & Villa Serena Apts \\
\hline Atlantic & 165 & Medium Density Residential & Lido Square Apts \\
\hline California & 40 & Low Density Residential & \\
\hline California & 387 & Low Density Residential & \\
\hline Civic & 50 & Low Density Residential & \\
\hline Civic & 56 & Low Density Residential & \\
\hline Civic & 101 & Low Density Residential & \\
\hline Civic & 153 & Low Density Residential & \\
\hline Marina & 26 & Low Density Residential & \\
\hline Marina & 200 & High Density Residential & Marina Heights Apts \\
\hline Old Town & 90 & Low Density Residential & \\
\hline Old Town & 116 & Low Density Residential & \\
\hline Old Town & 40 & Low Density Residential & \\
\hline Old Town & 120 & Medium Density Residential & \\
\hline Old Town & 2667 & High Density Residential & East Santa Fe Apts \\
\hline Old Town & & & Vidrio \\
\hline Base Total & High Density Residential & \\
\hline & & \\
\hline
\end{tabular}




\section{POTENTIAL TRIPS}

Table A 17. ALTERNATIVE 2: POPULATION OF POTENTIAL TRIP-MAKERS

\begin{tabular}{|l|r|r|r|r|r|}
\hline Age & $\begin{array}{l}\text { Under } \\
24\end{array}$ & $25-44$ & $45-64$ & \multicolumn{1}{l}{$\begin{array}{l}\text { Over } \\
64\end{array}$} & \multicolumn{1}{l}{ Sum } \\
\hline Atlantic Plaza Shopping Center & 0 & 1376 & 1152 & 405 & 2934 \\
\hline Century Plaza Shopping Center & 0 & 2482 & 2078 & 730 & 5290 \\
\hline Civic Center (City Hall, Court House, Library) & 0 & 2147 & 1798 & 631 & 4576 \\
\hline Hampton Inn (California Ave and Carion Ct) & 0 & 2482 & 2078 & 730 & 5290 \\
\hline North Park Plaza (WinCo Foods) & 0 & 2482 & 2078 & 730 & 5290 \\
\hline Old Town & 0 & 2048 & 1715 & 602 & 4366 \\
\hline Pittsburg Marina & 0 & 2272 & 1902 & 668 & 4842 \\
\hline Pittsburg/ Bay Point BART & 0 & 2482 & 2078 & 730 & 5290 \\
\hline Senior Center (Presidio Ln) & 0 & 1376 & 1152 & 405 & 2934 \\
\hline School (Pittsburg High, Marina Vista) & 0 & 2048 & 1715 & 602 & 4366 \\
\hline Sum & 0 & 21195 & 17748 & 6234 & \\
\hline
\end{tabular}

$$
L=P *[H *(U-A)]
$$

Where,

$L=$ population living within $1 / 4$ mile of a shuttle route that would make trips (Table A17)

$P=$ proportion of population in age group $(0.29$ for $25-44 ; 0.24$ for $45-63 ; 0.09$ for Over 64) (Census, 2010)

$H=$ average household size in Pittsburg (3.22) (Census, 2010)

$U=$ total housing units within $1 / 4$ mile of shuttle routes (2667) (Table A16)

$A=$ total number of units in area of trip origin (Table A16) 
Table A 18. WEIGHTED TRIPS (BY AGE GROUP)

\begin{tabular}{|c|c|c|c|c|}
\hline & \multicolumn{4}{|c|}{$\begin{array}{l}\text { Weighted daily trips made by } \\
\text { the age group }\end{array}$} \\
\hline & $\begin{array}{l}\text { Under } \\
24\end{array}$ & $25-44$ & $45-64$ & $\begin{array}{l}\text { Over } \\
64\end{array}$ \\
\hline Atlantic Plaza Shopping Center & 0 & 0.17 & 0.04 & 0.03 \\
\hline Century Plaza Shopping Center & 0 & 0.13 & 0.04 & 0.04 \\
\hline Civic Center (City Hall, Court House, Library) & 0 & 0.22 & 0.09 & 0.02 \\
\hline Hampton Inn (California Ave and Carion Ct) & 0 & 0.04 & 0.00 & 0.00 \\
\hline North Park Plaza (WinCo Foods) & 0 & 0.15 & 0.04 & 0.04 \\
\hline Old Town & 0 & 0.21 & 0.08 & 0.07 \\
\hline Pittsburg Marina & 0 & 0.08 & 0.04 & 0.04 \\
\hline Pittsburg/ Bay Point BART & 0 & 0.22 & 0.08 & 0.02 \\
\hline Senior Center (Presidio Ln) & 0 & 0.07 & 0.00 & 0.03 \\
\hline School (Pittsburg High, Marina Vista) & 0 & 0.03 & 0.03 & 0.01 \\
\hline
\end{tabular}

Table A 19. ALTERNATIVE 2: POTENTIAL TRIPS MADE BY POPULATION

\begin{tabular}{|l|r|r|r|r|r|}
\hline & $\begin{array}{l}\text { Under } \\
\text { 24 }\end{array}$ & $25-44$ & $\begin{array}{l}45-64 \\
\text { Over }\end{array}$ & Sum \\
\hline Atlantic Plaza Shopping Center & 0 & 9 & 2 & 0 & 12 \\
\hline Century Plaza Shopping Center & 0 & 13 & 3 & 1 & 17 \\
\hline Civic Center (City Hall, Court House, Library) & 0 & 19 & 6 & 0 & 26 \\
\hline Hampton Inn (California Ave and Carion Ct) & 0 & 4 & 0 & 0 & 4 \\
\hline North Park Plaza (WinCo Foods) & 0 & 15 & 4 & 1 & 20 \\
\hline Old Town & 0 & 17 & 6 & 2 & 25 \\
\hline Pittsburg Marina & 0 & 7 & 3 & 1 & 11 \\
\hline Pittsburg/ Bay Point BART & 0 & 22 & 6 & 1 & 29 \\
\hline Senior Center (Presidio Ln) & 0 & 4 & 0 & 0 & 4 \\
\hline School (Pittsburg High, Marina Vista) & 0 & 3 & 2 & 0 & 5 \\
\hline Sum & 0 & 112 & 32 & 8 & 152 \\
\hline
\end{tabular}

$$
T=\operatorname{HBShop}(L * W)
$$

Where,

$T=$ potential transit trips to a destination (Table A19)

HBShop $=$ Home-based-shopping trip made by transit (4 percent of trips)*

$L=$ population living within $1 / 4$ mile of a shuttle route that would make trips (Table A17)

$W=$ weighted daily trips by age group (Table A18)

*Source: Contra Costa Transportation Authority (2003) 
Table A 20. ALTERNATIVE 2: POTENTIAL TRIPS FROM SENIOR UNITS

\begin{tabular}{|l|l|}
\hline Trips from Senior Units & \\
\hline Atlantic Plaza Shopping Center & 0.38 \\
\hline Century Plaza Shopping Center & 0.54 \\
\hline Civic Center (City Hall, Court House, Library) & 0.23 \\
\hline Hampton Inn (California Ave and Carion Ct) & 0.00 \\
\hline North Park Plaza (WinCo Foods) & 0.46 \\
\hline Old Town & 0.92 \\
\hline Pittsburg Marina & 0.54 \\
\hline Pittsburg/ Bay Point BART & 0.31 \\
\hline Senior Center (Presidio Ln) & 0.38 \\
\hline School (Pittsburg High, Marina Vista) & 0.15 \\
\hline Sum & 3.91 \\
\hline
\end{tabular}

FINAL ADJUSTED POTENTIAL TRIPS MADE BY THE POPULATION

Table A 21. ALTERNATIVE 2: FINAL ADJUSTED POTENTIAL TRIPS MADE BY POPULATION

\begin{tabular}{|c|c|c|c|c|c|}
\hline & $\begin{array}{l}\text { Under } \\
24\end{array}$ & $25-44$ & $45-64$ & $\begin{array}{l}\text { Over } \\
64\end{array}$ & $\begin{array}{l}\text { Sub } \\
\text { Total }\end{array}$ \\
\hline Atlantic Plaza Shopping Center & 0 & 9 & 2 & 1 & 12 \\
\hline Century Plaza Shopping Center & 0 & 13 & 3 & 2 & 18 \\
\hline Civic Center (City Hall, Court House, Library) & 0 & 19 & 6 & 1 & 26 \\
\hline Hampton Inn (California Ave and Carion Ct) & 0 & 4 & 0 & 0 & 4 \\
\hline North Park Plaza (WinCo Foods) & 0 & 15 & 4 & 2 & 20 \\
\hline Old Town & 0 & 17 & 6 & 3 & 25 \\
\hline Pittsburg Marina & 0 & 7 & 3 & 2 & 12 \\
\hline Pittsburg/ Bay Point BART & 0 & 0 & 0 & & 0 \\
\hline Senior Center (Presidio Ln) & 0 & 0 & 0 & & 0 \\
\hline School (Pittsburg High, Marina Vista) & 0 & 0 & 0 & & 0 \\
\hline Sum ${ }^{*}$ & 0 & 84 & 24 & 9 & 117 \\
\hline
\end{tabular}

*The sum of Table A19 and A20 minus trips to areas with uncertain conditions. 


\section{AF. ALTERNATIVE 3: RIDERSHIP PROJECTION}

\section{HOUSING UNITS}

Table A 22. ALTERNATIVE 3: HOUSING UNITS WITHIN 1/4 MILE OF PROPOSED SHUTTLE ROUTES

\begin{tabular}{|c|c|c|c|}
\hline & Units & Land_Use & Name \\
\hline Atlantic & 118 & Low Density Residential & \\
\hline Atlantic & 26 & Low Density Residential & \\
\hline Atlantic & 170 & Low Density Residential & \\
\hline Atlantic & 118 & Low Density Residential & \\
\hline Atlantic & 45 & Medium Density Residential & \\
\hline Atlantic & 93 & Medium Density Residential & \\
\hline Atlantic & 204 & High Density Residential & Cornerstone Apts \\
\hline Atlantic & 76 & Medium Density Residential & Pittsburg Park Apts \\
\hline Atlantic & 125 & Medium Density Residential & Fox Creek Apts \\
\hline Atlantic & 48 & High Density Residential & Villa Serena Apts \\
\hline Atlantic & 165 & Medium Density Residential & Lido Square Apts \\
\hline Civic & 50 & Low Density Residential & \\
\hline Civic & 56 & Low Density Residential & \\
\hline Civic & 101 & Low Density Residential & \\
\hline Civic & 153 & Low Density Residential & \\
\hline East Leland & 156 & High Density Residential & Meridian Apts \\
\hline East Leland & 208 & High Density Residential & Presidents Park Apts \\
\hline East Leland & 242 & High Density Residential & Pheasants Ridge Apts \\
\hline East Leland & 132 & High Density Residential & Lakeview Apts \\
\hline East Leland & 148 & High Density Residential & Loveridge Terrace Apts \\
\hline East Leland & 80 & High Density Residential & Woods Grove Apts \\
\hline East Leland & 114 & Medium Density Residential & \\
\hline East Leland & 120 & Medium Density Residential & \\
\hline East Leland & 30 & Low Density Residential & \\
\hline Marina & 26 & Low Density Residential & \\
\hline Marina & 200 & High Density Residential & Marina Heights Apts \\
\hline Old Town & 90 & Low Density Residential & \\
\hline Old Town & 116 & Low Density Residential & \\
\hline Old Town & 40 & Low Density Residential & \\
\hline Old Town & 120 & Medium Density Residential & \\
\hline Old Town & 25 & High Density Residential & East Santa Fe Apts \\
\hline Old Town & 75 & High Density Residential & Vidrio \\
\hline Base Total & 3470 & & \\
\hline
\end{tabular}




\section{POTENTIAL TRIPS}

Table A 23. ALTERNATIVE 3: POPULATION OF POTENTIAL TRIP-MAKERS

\begin{tabular}{|c|c|c|c|c|c|}
\hline Age & $\begin{array}{l}\text { Under } \\
24\end{array}$ & $25-44$ & $45-64$ & $\begin{array}{l}\text { Over } \\
64\end{array}$ & Sum \\
\hline Atlantic Plaza Shopping Center & 0 & 2124 & 1778 & 625 & 4526 \\
\hline Century Plaza Shopping Center & 0 & 3229 & 2704 & 950 & 6883 \\
\hline Civic Center (City Hall, Court House, Library) & 0 & 2894 & 2423 & 851 & 6169 \\
\hline Hampton Inn (California Ave and Carion Ct) & 0 & 3229 & 2704 & 950 & 6883 \\
\hline North Park Plaza (WinCo Foods) & 0 & 3229 & 2704 & 950 & 6883 \\
\hline Old Town & 0 & 2795 & 2341 & 822 & 5958 \\
\hline Pittsburg Marina & 0 & 3019 & 2528 & 888 & 6435 \\
\hline Pittsburg/ Bay Point BART & 0 & 3229 & 2704 & 950 & 6883 \\
\hline Senior Center (Presidio Ln) & 0 & 2124 & 1778 & 625 & 4526 \\
\hline School (Pittsburg High, Marina Vista) & 0 & 2795 & 2341 & 822 & 5958 \\
\hline Sum & 0 & 28667 & 24005 & 8432 & \\
\hline
\end{tabular}

$$
L=P *[H *(U-A)]
$$

Where,

$L=$ population living within $1 / 4$ mile of a shuttle route that would make trips (Table A23)

$P=$ proportion of population in age group $(0.29$ for $25-44 ; 0.24$ for $45-63 ; 0.09$ for Over 64) (Census, 2010)

$H=$ average household size in Pittsburg (3.22) (Census, 2010)

$U=$ total housing units within $1 / 4$ mile of shuttle routes (3470) (Table A22)

$A=$ total number of units in area of trip origin (Table A22) 
Table A 24. WEIGHTED TRIPS (BY AGE GROUP)

\begin{tabular}{|c|c|c|c|c|}
\hline & \multicolumn{4}{|c|}{$\begin{array}{l}\text { Weighted daily trips made by } \\
\text { the age group }\end{array}$} \\
\hline & $\begin{array}{l}\text { Under } \\
24\end{array}$ & $25-44$ & $45-64$ & $\begin{array}{l}\text { Over } \\
64\end{array}$ \\
\hline Atlantic Plaza Shopping Center & 0 & 0.17 & 0.04 & 0.03 \\
\hline Century Plaza Shopping Center & 0 & 0.13 & 0.04 & 0.04 \\
\hline Civic Center (City Hall, Court House, Library) & 0 & 0.22 & 0.09 & 0.02 \\
\hline Hampton Inn (California Ave and Carion Ct) & 0 & 0.04 & 0.00 & 0.00 \\
\hline North Park Plaza (WinCo Foods) & 0 & 0.15 & 0.04 & 0.04 \\
\hline Old Town & 0 & 0.21 & 0.08 & 0.07 \\
\hline Pittsburg Marina & 0 & 0.08 & 0.04 & 0.04 \\
\hline Pittsburg/ Bay Point BART & 0 & 0.22 & 0.08 & 0.02 \\
\hline Senior Center (Presidio Ln) & 0 & 0.07 & 0.00 & 0.03 \\
\hline School (Pittsburg High, Marina Vista) & 0 & 0.03 & 0.03 & 0.01 \\
\hline
\end{tabular}

Table A 25. ALTERNATIVE 3: POTENTIAL TRIPS MADE BY POPULATION

\begin{tabular}{|l|r|r|r|r|r|}
\hline & $\begin{array}{l}\text { Under } \\
24\end{array}$ & $25-44$ & $45-64$ & $\begin{array}{l}\text { Over } \\
64\end{array}$ & Sum \\
\hline Atlantic Plaza Shopping Center & 0 & 14 & 3 & 1 & 18 \\
\hline Century Plaza Shopping Center & 0 & 17 & 4 & 2 & 23 \\
\hline Civic Center (City Hall, Court House, Library) & 0 & 26 & 9 & 1 & 35 \\
\hline Hampton Inn (California Ave and Carion Ct) & 0 & 5 & 0 & 0 & 5 \\
\hline North Park Plaza (WinCo Foods) & 0 & 19 & 5 & 1 & 25 \\
\hline Old Town & 0 & 23 & 8 & 2 & 33 \\
\hline Pittsburg Marina & 0 & 9 & 4 & 2 & 15 \\
\hline Pittsburg/ Bay Point BART & 0 & 29 & 8 & 1 & 38 \\
\hline Senior Center (Presidio Ln) & 0 & 6 & 0 & 1 & 6 \\
\hline School (Pittsburg High, Marina Vista) & 0 & 4 & 2 & 0 & 7 \\
\hline Sum & 0 & 152 & 44 & 10 & 206 \\
\hline
\end{tabular}

$$
T=\operatorname{HBShop}(L * W)
$$

Where,

$T=$ potential transit trips to a destination (Table A25)

HBShop $=$ Home-based-shopping trip made by transit (4 percent of trips) ${ }^{*}$

$L=$ population living within $1 / 4$ mile of a shuttle route that would make trips (Table A23)

$W=$ weighted daily trips by age group(Table A24)

*Source: Contra Costa Transportation Authority (2003) 
Table A 26. ALTERNATIVE 3: POTENTIAL TRIPS FROM SENIOR UNITS

\begin{tabular}{|l|l|}
\hline Trips from Senior Units & \\
\hline Atlantic Plaza Shopping Center & 0.38 \\
\hline Century Plaza Shopping Center & 0.54 \\
\hline Civic Center (City Hall, Court House, Library) & 0.23 \\
\hline Hampton Inn (California Ave and Carion Ct) & 0.00 \\
\hline North Park Plaza (WinCo Foods) & 0.46 \\
\hline Old Town & 0.92 \\
\hline Pittsburg Marina & 0.54 \\
\hline Pittsburg/ Bay Point BART & 0.31 \\
\hline Senior Center (Presidio Ln) & 0.38 \\
\hline School (Pittsburg High, Marina Vista) & 0.15 \\
\hline Sum & 3.91 \\
\hline
\end{tabular}

FINAL ADJUSTED POTENTIAL TRIPS MADE BY THE POPULATION

Table A 27. ALTERNATIVE 3: FINAL ADJUSTED POTENTIAL TRIPS MADE BY POPULATION

\begin{tabular}{|l|r|r|r|r|r|}
\hline & $\begin{array}{l}\text { Under } \\
24\end{array}$ & $25-44$ & $\begin{array}{l}45-64 \\
\text { Over } \\
\text { Atlantic Plaza Shopping Center }\end{array}$ & $\begin{array}{l}\text { Sub } \\
\text { Total }\end{array}$ \\
\hline Century Plaza Shopping Center & 0 & 14 & 3 & 1 & 19 \\
\hline Civic Center (City Hall, Court House, Library) & 0 & 26 & 9 & 2 & 23 \\
\hline Hampton Inn (California Ave and Carion Ct) & 0 & 5 & 0 & 0 & 35 \\
\hline North Park Plaza (WinCo Foods) & 0 & 19 & 5 & 2 & 26 \\
\hline Old Town & 0 & 23 & 8 & 3 & 34 \\
\hline Pittsburg Marina & 0 & 9 & 4 & 2 & 16 \\
\hline Pittsburg/ Bay Point BART & 0 & 0 & 0 & 0 & 0 \\
\hline Senior Center (Presidio Ln) & 0 & 0 & 0 & 0 & 0 \\
\hline School (Pittsburg High, Marina Vista) & 0 & 0 & 0 & 0 & 0 \\
\hline Sum & 0 & 113 & 33 & 11 & 158 \\
\hline
\end{tabular}

*The sum of Table A25 and A26 minus trips to areas with uncertain conditions. 
APPENDIX B: SURVEYS

Table B 1. SURVEY RESPONSES

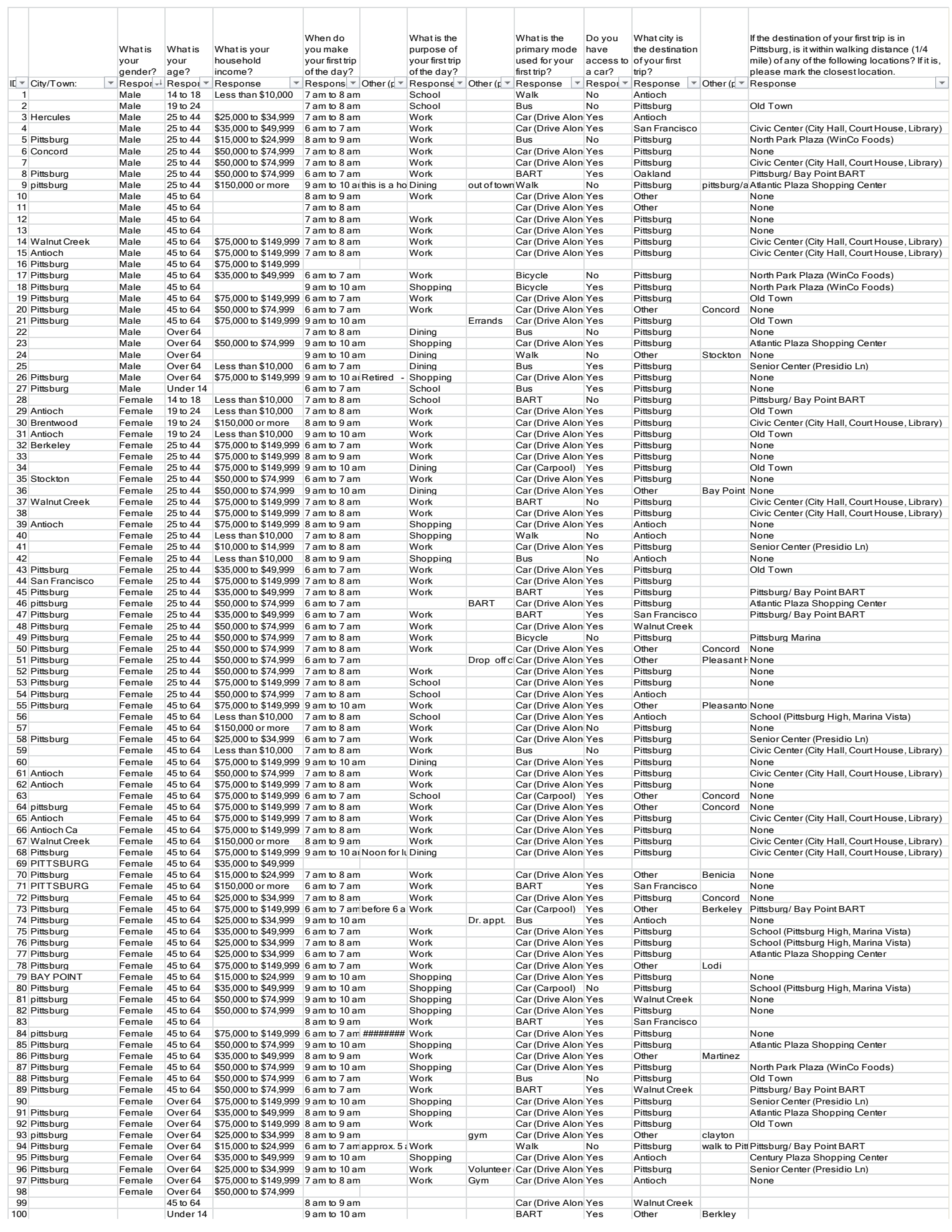




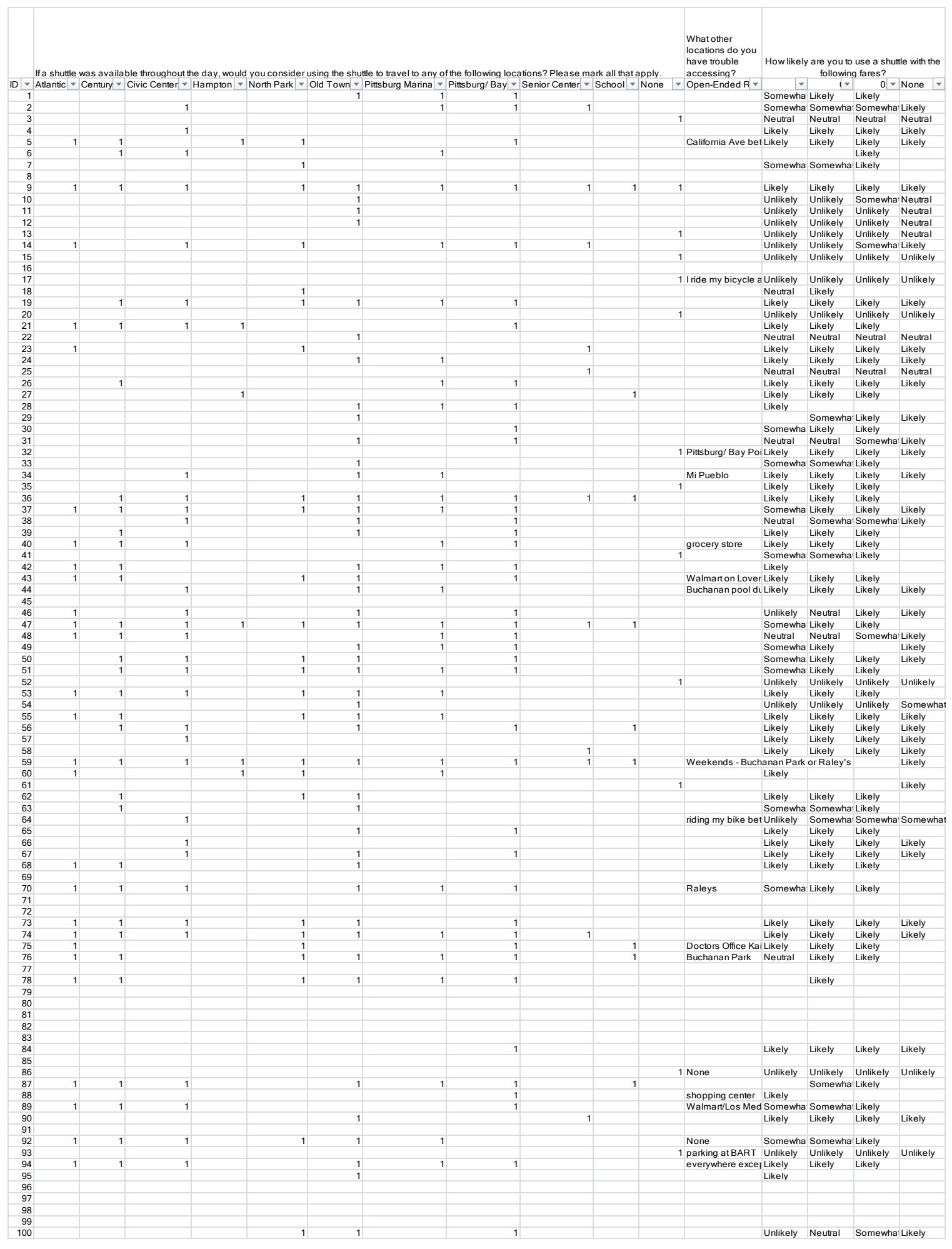

148 | P a g e 
Figure B 1. NUMBER OF TRIPS TO DESTINATIONS (BY DAY OF WEEK)

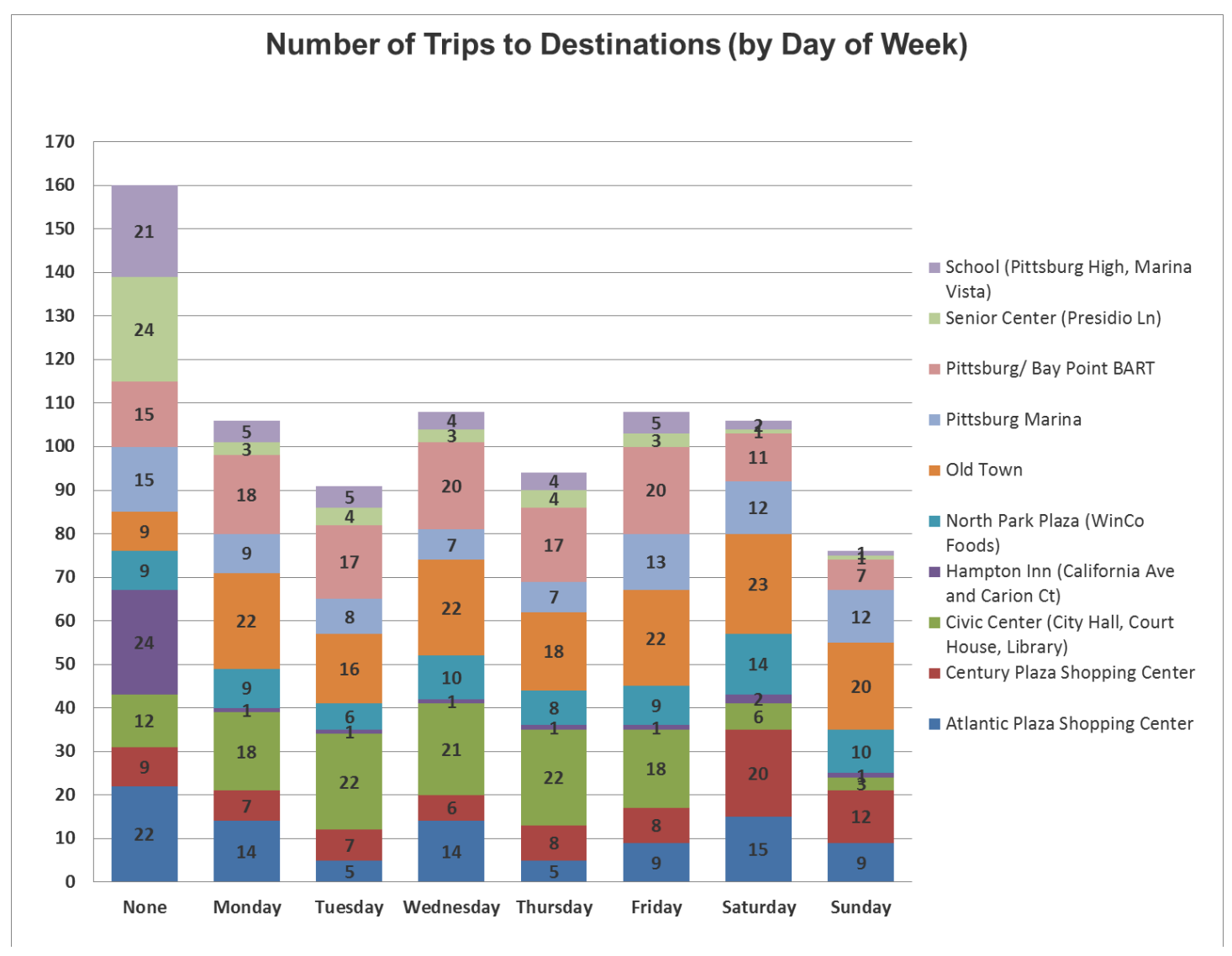


Figure B 2. NUMBER OF TRIPS TO DESTINATIONS (BY LOCATION)

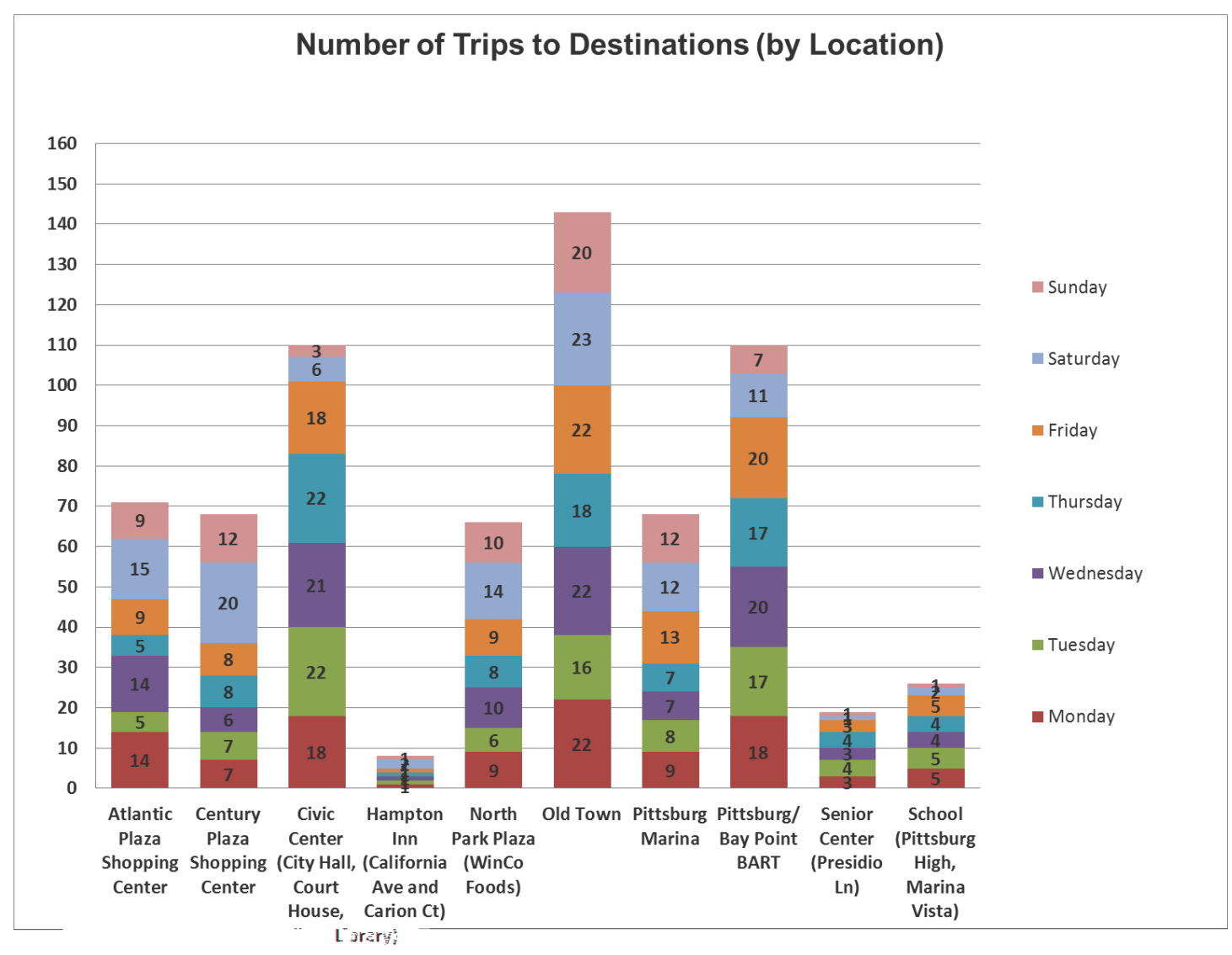




\section{City of Pittsburg Shuttle Study Survey}

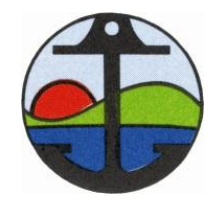

\section{$\underline{\text { Informed Consent Form }}$}

\section{INFORMED CONSENT TO PARTICIPATE IN CIRCULATOR SHUTTLE IMPLEMENTATION PLAN FOR THE CITY OF PITTSBURG.}

A research project on a shuttle bus transportation service in Pittsburg is being conducted by Justin Shiu in the Department of City and Regional Planning at Cal Poly, San Luis Obispo. The purpose of the study is to determine unmet transportation needs, gauge interest in new transportation options around the city, and understand how a shuttle system can most effectively serve residents and visitors.

You are being asked to take part in this study by completing the attached/enclosed questionnaire. Please choose from the listed answers under each question or write in a response when the choice is provided. Your participation will take approximately 5 to 10 minutes. Please be aware that you are not required to participate in this research and you may discontinue your participation at any time without penalty. You may also omit any items on the questionnaire you prefer not to answer.

Your responses will be provided anonymously to protect your privacy. Potential benefits associated with the study include improving this study's understanding of travel needs in Pittsburg and providing information to support proposals for improved transportation options in the city. You will also have a chance to win a gift certificate. A winner will be selected randomly from all participants of the survey.

If you have questions regarding this study or would like to be informed of the results when the study is completed, please feel free to contact Justin Shiu at (510) 417-9362. If you have questions or concerns regarding the manner in which the study is conducted, you may contact Dr. Steve Davis, Chair of the Cal Poly Human Subjects Committee, at (805) 756-2754, sdavis@calpoly.edu, or Dr. Susan Opava, Dean of Research and Graduate Programs, at (805) 756-1508, sopava@calpoly.edu. For questions directed to the City, you may contact Laura Wright, at (925) 252-4114, LWright@ci.pittsburg.ca.us.

If you agree to voluntarily participate in this research project as described, please indicate your agreement by completing and returning the attached questionnaire. Please retain this consent cover form for your reference, and thank you for your participation! 


\section{INTRODUCTION}

The City of Pittsburg would like to know if a shuttle service can meet your daily needs. This survey intends to gather information about the characteristics of your trips. If you have children under the age of 18, please fill out a survey on their behalf. Your information will be kept confidential and will only be used for the purposes of this study. Answers that can specifically be linked to you will not be published.

\section{DEMOGRAPHICS}

What is your address? (This information will be used to determine your access to transit.)

What is your gender?

\begin{tabular}{|l|l|}
\hline Male & \\
\hline Female & \\
\hline
\end{tabular}

What is your age?

\begin{tabular}{|l|l|}
\hline Under 14 & \\
\hline $14-18$ & \\
\hline $19-24$ & \\
\hline $25-44$ & \\
\hline $45-64$ & \\
\hline Over 64 & \\
\hline
\end{tabular}

What is your household income?

\begin{tabular}{|l|l|}
\hline Less than $\$ 10,000$ & \\
\hline$\$ 10,000$ to $\$ 14,999$ & \\
\hline$\$ 15,000$ to $\$ 24,999$ & \\
$\$ 25,000$ to $\$ 34,999$ & \\
\hline$\$ 35,000$ to $\$ 49,999$ & \\
\hline$\$ 50,000$ to $\$ 74,999$ & \\
\hline$\$ 75,000$ to $\$ 149,999$ & \\
\hline$\$ 150,000$ or more & \\
\hline
\end{tabular}

\section{FIRST TRIP}

When do you make your first trip of the day?

\begin{tabular}{|l|l|}
\hline $6-7$ & \\
\hline $7-8$ & \\
\hline $8-9$ & \\
\hline $9-10$ & \\
\hline Other & \\
\hline
\end{tabular}

What is the purpose of your first trip of the day? Please mark one.

\begin{tabular}{|l|l|}
\hline Work & \\
\hline School & \\
\hline Shopping & \\
\hline Dining & \\
\hline Other & \\
\hline
\end{tabular}

What is the primary mode used for your first trip? Please mark one.

\begin{tabular}{|l|l|}
\hline Car (Drive Alone) & \\
\hline Car (Carpool) & \\
\hline Bike & \\
\hline Bus & \\
\hline BART & \\
\hline Walk & \\
\hline
\end{tabular}

Do you have access to a car? $\mathrm{Y} / \mathrm{N}$

What city is the destination of your first trip? Please mark one.

\begin{tabular}{|l|l|}
\hline Pittsburg & \\
\hline Antioch & \\
\hline Walnut Creek & \\
\hline Oakland & \\
\hline San Francisco & \\
\hline Other & \\
\hline
\end{tabular}

If you marked Other, please state the destination.

If the destination of your first trip is in Pittsburg, is it within walking distance $(1 / 4$ mile) of any of the following locations? If it is, please mark the closest location.

\begin{tabular}{|l|l|}
\hline Atlantic Plaza Shopping Center & \\
\hline Century Plaza Shopping Center & \\
\hline Civic Center (City Hall, Court House) & \\
\hline Hampton Inn (California Ave and Carion Ct) & \\
\hline North Park Plaza (WinCo Foods) & \\
\hline Old Town & \\
\hline Pittsburg Marina & \\
\hline Pittsburg/Bay Point BART & \\
\hline Senior Center (Presidio Lane) & \\
\hline School (Pittsburg High, Marina Vista, St. Peter Martyr) & \\
\hline
\end{tabular}




\section{TRIPS WITHIN THE CITY}

In a typical week, which days do you travel from your home to any of the following locations? Please mark all that apply.

\begin{tabular}{|l|l|l|l|l|l|l|l|}
\hline Atlantic Plaza Shopping Center & Monday & Tuesday & Wednesday & Thursday & Friday & Saturday & Sunday \\
\hline Century Plaza Shopping Center & & & & & & & \\
\hline Civic Center (City Hall, Court) & & & & & & & \\
\hline $\begin{array}{l}\text { Hampton Inn (California Ave } \\
\text { and Carion Ct) }\end{array}$ & & & & & & & \\
\hline North Park Plaza (WinCo Foods) & & & & & & & \\
\hline Old Town & & & & & & & \\
\hline Pittsburg Marina & & & & & & \\
\hline Pittsburg/Bay Point BART & & & & & & & \\
\hline Senior Center (Presidio Lane) & & & & & & & \\
\hline $\begin{array}{l}\text { School (Pittsburg High, Marina } \\
\text { Vista, St. Peter Martyr) }\end{array}$ & & & & & & & \\
\hline
\end{tabular}

If a shuttle was available throughout the day, would you consider using the shuttle to travel to any of the following locations? Please mark all that apply.

\begin{tabular}{|l|l|}
\hline Atlantic Plaza Shopping Center & \\
\hline Century Plaza Shopping Center & \\
\hline Hampton Inn (California Ave and Carion Ct) & \\
\hline North Park Plaza (WinCo Foods) & \\
\hline Old Town & \\
\hline Pittsburg Marina & \\
\hline Pittsburg/Bay Point BART & \\
\hline Senior Center (Presidio Lane) & \\
\hline School (Pittsburg High, Marina Vista, St. Peter Martyr) & \\
\hline
\end{tabular}

What other locations in Pittsburg do you have trouble accessing with your transportation options?

\section{WILLINGNESS TO PAY}

How likely are you to use a shuttle with the following fares?

\begin{tabular}{|l|l|l|l|l|}
\hline & $\$ 1.00$ & $\$ 0.50$ & $\$ 0.25$ & None \\
\hline Likely & & & & \\
\hline Somewhat Likely & & & & \\
\hline Neutral & & & & \\
\hline Somewhat unlikely & & & & \\
\hline Unlikely & & & & \\
\hline
\end{tabular}

Thanks you for participating in this survey! Your feedback is very important to this study. Do you have any additional comments that can help us improve your travel options around Pittsburg? 


\section{City of Pittsburg Shuttle Study Survey}

The City of Pittsburg would like to know how to better connect patrons to local businesses and provide additional transportation options like shuttles. This survey intends to gather information about your preferred connections to locations around the city and your willingness to contribute to increased transportation options for your employees and your patrons. Your personal information will be kept confidential and will only be used for the purposes of this study.

How important is a connection between the following locations and your business?

\begin{tabular}{|l|l|l|l|l|l|}
\hline & $\begin{array}{l}\text { Very } \\
\text { Important }\end{array}$ & $\begin{array}{l}\text { Somewhat } \\
\text { Important }\end{array}$ & Neutral & $\begin{array}{l}\text { Somewhat } \\
\text { Unimportant }\end{array}$ & $\begin{array}{l}\text { Not } \\
\text { Important }\end{array}$ \\
\hline Atlantic Plaza Shopping Center & & & & & \\
\hline Century Plaza Shopping Center & & & & & \\
\hline Civic Center (City Hall, Court House) & & & & & \\
\hline Sienna Court (Old Town Senior Village) & & & & & \\
\hline Hampton Hotel (California Ave and Carion Ct) & & & & & \\
\hline North Park Plaza (WinCo Foods) & & & & & \\
\hline Old Town & & & & & \\
\hline Pittsburg Marina & & & & & \\
\hline Pittsburg/Bay Point BART & & & & & \\
\hline Senior Center (Presidio Lane) & & & & & \\
\hline $\begin{array}{l}\text { School (Pittsburg High, Marina Vista, St. Peter } \\
\text { Martyr) }\end{array}$ & & & & & \\
\hline eBART Station - Railroad Ave (planned) & & & & & \\
\hline Other & & & & & \\
\hline
\end{tabular}

If you marked Other, please state the location.

How likely are you to contribute the following amounts per month for a shuttle service that stops within walking distance (less than $1 / 4$ mile) of your business?

\begin{tabular}{|l|l|l|l|l|l|} 
& Likely & $\begin{array}{l}\text { Somewhat } \\
\text { Likely }\end{array}$ & Neutral & $\begin{array}{l}\text { Somewhat } \\
\text { Unlikely }\end{array}$ & Unlikely \\
\hline \$100 (\$4 per day) & & & & & \\
\hline \$50 (\$2 per day) & & & & & \\
\hline \$25 (\$1 per day) & & & & & \\
\hline None & & & & & \\
\hline
\end{tabular}

What is your business location? Please provide an address or the cross streets.

Thank you for participating in this survey! Your feedback is very important to this study. Do you have any additional comments that can help us improve travel options around Pittsburg? 


\section{REFERENCES}

American Public Transportation Association (APTA). (2011). Public Transportation Factbook. Washington D.C: American Public Transportation Association.

Bay Area Air Quality Management District (BAAQMD). (2012a). County Program Manager Fund expenditure plan guidance fiscal year ending 2013. Retrieved from http://www.baaqmd.gov/ /media/Files/Strategic\%20Incentives/TFCA/Program\%20M anager\%20Fund/TFCA\%20Program\%20Mgr\%20Guide\%20FYE\%202013.ashx

Bay Area Air Quality Management District (BAAQMD). (2012b). Grant opportunity announcement for shuttle/feeder bus and regional ridesharing projects: Guidance, policies, and evaluation criteria for fiscal year ending (FYE) 2013. Retrieved from http://www.baaqmd.gov/ /media/Files/Strategic\%20Incentives/TFCA/TFCA\%20Regi onal\%20Fund\%20Guidance\%20FYE\%202013\%20FINAL.ashx

Boarnet, M. and Crane, R. (2001). Travel by design: the influence of urban form on travel. New York: Oxford University Press.

Bruun, E. (2007). Better public transit systems: analyzing investments and performance. Chicago, IL: Planner's Press, American Planning Association.

Center for Transit-Oriented Development (CTOD). (2009). Mixed-income housing: Increasing affordability with transit.

Cervero, R. (2007). Transit-oriented development's ridership bonus: A product of self-selection and public policies. Environment and Planning A, 39(9), 2068-2085.

Charles River Associates Incorporated. (1997). Building transit ridership: An exploration of transit's market share and the public policies that influence it. Transit Cooperative Research Program. Washington D.C: National Academy Press.

Chen, C., Varley, D., \& Chen, J. (2011). What affects transit ridership? A dynamic analysis involving multiple factors, lags, and asymmetric behavior. Urban Studies, 48(9), 1893-1908.

Chiang, W., Russel, R., \& Urban, T. (2011). Forecasting ridership for a metropolitan transit authority. Transportation Research Part A, 45(7), 696-705.

City of Pittsburg. (2009). Railroad Avenue station area specific plan. Retrieved from http://www.ci.pittsburg.ca.us/index.aspx?page=209

Contra Costa Transportation Authority (CCTA). (2011). Planning committee staff report: Approval of FY 2011-12 transportation fund for clean air 40 percent expenditure plan. 
Contra Costa Transportation Authority (CCTA). (2003). Decennial model update. Retrieved from http://www.ccta.net/EN/main/planning/1241/traveldemand.html

Crowlet, D., Shalaby, A., and Zarei, H. (2009). Access walking distance, transit use, and transit-oriented development in North York City Center, Toronto, Canada. Transportation Research Record No. 211, 96-105.

Deuker, K., Kimpel, T., Strathman, J., and Callas, S. (2004). Determinants of bus dwell time. Journal of Public Transportation, 7(1), 21-40.

Dixit, V., Rutstrom, E., Mard, M.and Zielske, R. (2010). Transit referenda and funding options: Bonds versus taxes. Transportation Research Record No 2143, 44-47.

East Contra Costa Transit Authority (ECCTA). (2008). Tri Delta Transit short range transit plan. Retrieved from http://www.trideltatransit.com/public.aspx

Ebus. (2012). Product line. Retrieved from http://www.ebus.com.

Garber, N. and Hoel, L. (2010). Traffic and highway engineering, $4^{\text {th }}$ edition. Stamford, Connecticut: Cengage Learning.

Gomez, M. (2010, December 20). Oakland looks to expand popular 'Free B' Shuttle. San Francisco Chronicle. Retrieved from http://articles.sfgate.com/2010-12-20/bay-area/25209888 1 shuttle-zach-seal-riders

Gould, J., Zhou, J. (2010). A social experiment to encourage drive-alone commuters to try-Transit'. Transportation Research Record, 2144, 93-101.

Hanson, S., and Guilano, G. (2004) The geography of urban transportation. New York: Guilford Press

Institute of Transportation Engineers (ITE). (2009). Transportation planning handbook $3^{\text {rd }}$ edition. Washington, D.C. : Institute of Transportation Engineers.

Jacques, K. and Levinson, H. (1997). "Examples of research applications." TCRP 26 Operational Analysis of Bus Lanes on Arterials. Washington D.C.: National Academy Press.

Kim, S. (2005). The effects of fixed-route transit service contracting on labor. (Unpublished Doctoral Dissertation). University of California, Berkeley.

Maghelal, P. (2011). Investigating the relationships among rising fuel prices, increased transit ridership, and CO2 emissions. Transportation Research Part D, 16(3), 232-235.

Martin, W. and McGuckin, N. (1998). NCHRP Report 365: Travel estimation techniques for urban planning. Washington D.C.: National Academy Press.

McCullough, W.S. III, B.D. Taylor, and M. Wachs. 1998. Transit Service Contracting and Cost-Efficiency. In Transportation Research Record, 1618, 69-77. 
Mohammadian, K., Takuriah, P., \& Rashidi, T. (2009). Effectiveness of transit strategies targeting elderly people. Chicago: Illinois Center for Transportation.

National Center for Transit Research (NCTR). (2011). Analysis of contracting for fixed route bus service. Tampa, FL: Center for Urban Transportation Research.

NTD. (2012). National transit database glossary. Retrieved from http://www.ntdprogram.gov/ntdprogram/Glossary.htm.

Nuworsoo, C. (2004). Deep discount group pass programs as instruments of increasing transit revenue and ridership. (Doctoral Dissertation). University of California, Berkeley.

Peck, M. (2010). Barriers to using fixed-route public transit for older adults. Mineta Transportation Institute Report. San Jose, CA: Mineta Transportation Institute.

Pritchett, G. (2012, Apr. 30). Cost of owning and operating a vehicle has increased 1.9 percent according to AAA's 2012 your driving cost study. Retrieved from http://newsroom.aaa.com/2012/04.

Proulx, F. (2012). White paper: First/ last mile shuttles in the San Francisco Bay Area. (Unpublished). University of California, Berkeley.

Regional Transportation District (2008). Shuttle and circulator services: Review and evaluation. Retrieved from http://www.rtd-denver.com/PDF Files/ServiceD/PerfReport Shuttle Circulator Repo rt 2008.pdf

Southern California Association of Governments. (2009). Maximizing mobility in Los Angeles: First and last mile strategies - volume II appendices. Retrieved from http://www.scag.ca.gov/nonmotorized/pdfs/LA-Maximizing-Mobility-Final-Vol2-Appen dix1.pdf.

Sperling, D. and Gordon, D. (2009). Two billion cars driving toward sustainability. New York: Oxford University Press.

Teal, R.F. 1985. Transit service contracting: Experiences and issues. Transportation Research Record, 1036, 28-36.

Transit Resource Center. (2004). Community oriented transit best practices. Grass Valley, CA: Transit Resource Center.

US Census. (2011). American community survey 1-year estimates: DP-03 select economic characteristics. Retrieved from http://factfinder2.census.gov.

US Census. (2010). Decennial census 2010: DP-01 Profile of general population and housing characteristics - Contra Costa County. Retrieved from http://factfinder2.census.gov. 
US Census. (2010). Decennial census 2010: DP-01 Profile of general population and housing characteristics - Pittsburg. Retrieved from http://factfinder2.census.gov.

US Census. (2010). Decennial census 2010: DP-03 Profile of selected economic characteristics - Pittsburg. Retrieved from http://factfinder2.census.gov.

Victoria Transport Policy Institute (VTPI). (2010, Dec. 13). Shuttle services. Retrieved from http://www.vtpi.org/.

Zullo, R. (2007). Transit contracting reexamined: Determinants of cost efficiency and resource allocation. Journal of Public Administration Research, 18, 495-515. 